\author{
UNIVERSIDADE DE SÃO PAULO \\ ESCOLA DE ENGENHARIA DE LORENA
}

LÍVIA TEREZINHA PIMENTEL BRANCO

Estudo de alternativas para a reciclagem mecânica de resíduos poliméricos industriais combinados com outros materiais 



\title{
ESTUDO DE ALTERNATIVAS PARA A RECICLAGEM MECÂNICA DE RESÍDUOS POLIMÉRICOS INDUSTRIAIS COMBINADOS COM OUTROS MATERIAIS
}

\begin{abstract}
Tese de doutorado apresentada à Escola de Engenharia de Lorena da Universidade de São Paulo para obtenção do título de Doutor em Ciências do Programa de PósGraduação em Engenharia de Materiais na área de concentração de Materiais Convencionais e Avançados.
\end{abstract}

Orientador: Prof. Dr. Clodoaldo Saron

Versão Corrigida

Lorena

2020 

AUTORIZO A REPRODUÇÃO E DIVULGAÇÃO TOTAL OU PARCIAL DESTE TRABALHO, POR QUALQUER MEIO CONVENCIONAL OU ELETRÔNICO, PARA FINS DE ESTUDO E PESQUISA, DESDE QUE CITADA A FONTE

Ficha catalográfica elaborada pelo Sistema Automatizado da Escola de Engenharia de Lorena, com os dados fornecidos pelo(a) autor(a)

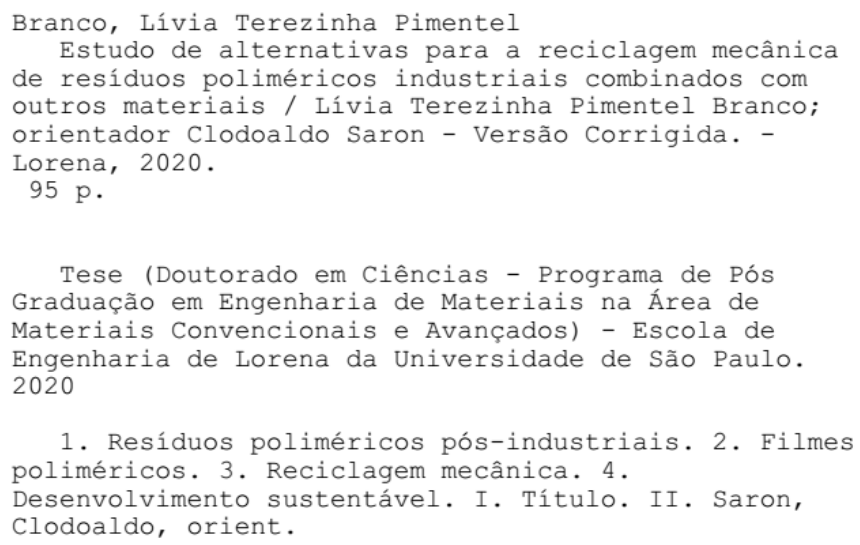

1. Resíduos poliméricos pós-industriais. 2. Filmes poliméricos. 3. Reciclagem mecânica. 4.

Desenvolvimento sustentável. I. Título. II. Saron, Clodoaldo, orient. 
A toda minha família, em especial à minha filha Sophia, aos meus pais, Ideusa e Leonel, ao meu irmão Leonel Jr. e ao meu companheiro de vida Nabil com amor, admiração e gratidão por toda compreensão, carinho, presença e incansável apoio ao longo do período de elaboração deste trabalho. 



\section{AGRADECIMENTOS}

Ao Prof. Dr. Clodoaldo Saron, por ter dito sim à minha educação e formação, por ter acreditado que seria possível a realização desse projeto e que eu seria capaz de realizá-lo, mesmo quando o tempo não era nosso aliado, enfim pela oportunidade de podermos trabalhar juntos. Agradeço também, ao meu orientador, por todos os ensinamentos dados, pelos cuidados e atenção com o meu crescimento científico e intelectual.

À minha filha Sophia que mostra diariamente como ser uma pessoa e profissional melhor e à toda minha família principalmente aos meus pais Ideusa e Leonel, ao meu irmão Leonel Jr. e ao meu companheiro de vida Dr. Nabil Chaia que sempre esteve presente nessa caminhada, compartilhando seus conhecimentos, dando atenção e apoio necessário para a minha formação, e por passar a mensagem de que o ensino forma pessoas, mas somente a educação e à ética são capazes de transformá-las em seres humanos melhores.

À Profa. Dra. Maria Auxiliadora M. Barreto, pela atenção, cuidado com a minha formação, suporte, ensinamentos dados e por passar uma mensagem de Paulo Freire, tanto em sua teoria quanto em sua prática, de que o exercício de ensinar não é apenas transferir o conhecimento, mas criar oportunidades para a sua construção no dia a dia.

À Profa. Dra. Jayne C. S. Barbosa, pelos ensinamentos dados e suporte técnico no uso de métodos espectroscópicos, atenção, apoio e preocupação com a minha formação desde do início do meu doutorado e por mostrar o quão bela pode ser uma pessoa que sempre está preocupada com o próximo, dando o seu melhor em tudo que se propõe a fazer.

Ao Prof. Dr. Durval Rodrigues, pelos ensinamentos dados, pela atenção, e colaborações e sugestões dadas no meu exame de qualificação e por todo suporte dado durante o meu curso de doutorado.

Ao Prof. Dr. Fernando Vernilli, pela atenção e suporte durante o meu curso de doutorado.

Ao pesquisador Dr. Diego Pizon pela amizade, parceria, pela incansável busca em poder ajudar o próximo, pelos ensinamentos, atenção e suporte dados durante meu doutorado. 
À Me. Rayane Veloso de Camargo pela amizade, parceria, ensinamentos dados e pela doação de material para esta pesquisa.

À Me. e doutoranda Camila Grillo pela amizade, parceria, pelos ensinamentos dados e todo o suporte durante meu doutorado.

Aos demais alunos do meu grupo pela parceria e ensinamentos dados.

Aos funcionários Aílton Rodrigues da Silva, Bento Ferreira, Sérgio L. Oliveira, Carlos Roberto Dainesi, Carlos Roberto Bernardo, Regina Amorim, Maria Alice Alves da Silva e demais professores doutores e pesquisadores, e aos funcionários responsáveis pela administração, manutenção e limpeza da universidade, pelo cuidado, suporte, atenção e ensinamentos dados durante meu doutorado.

Aos alunos da minha sala, A-13, pela companheirismo, amizade, atenção e ensinamento dados.

À Profa. Raquel C. Batista, pela atenção, carinho e ensinamentos dados.

À Universidade de São Paulo (USP) e à Escola de Engenharia de Lorena (EEL), e ao Departamento de Engenharia de Materiais (DEMAR), pela oportunidade de realização do curso de doutorado.

À Coordenação de Aperfeiçoamento de Pessoal de Nível Superior (CAPES), pela concessão de bolsa de doutorado e pelo apoio financeiro para a realização desta pesquisa.

À Fundação de Amparo à Pesquisa do Estado de São Paulo (FAPESP), pelo apoio financeiro para a realização desta pesquisa.

À empresa Johnson\&Johnson Brasil, á Supervisora Mariana Abreu da Unidade de Reciclagem, ao Fábio Mendes Machado e demais funcionários pela parceria e doação de materiais destinados para essa pesquisa.

À Pró-Reitora de Pós-Graduação, pela concessão do auxílio financeiro destinado à realização de um estágio científico numa universidade no exterior.

À Universidade de Massachusetts - Amherst, aos funcionários e aos alunos, pela oportunidade de realização de um estágio científico e pela contribuição para o meu crescimento intelectual e científico. 
BRANCO, L. T. P. Estudo de alternativas para a reciclagem mecânica de resíduos poliméricos industriais combinados com outros materiais. 2019. 95p. Tese (Doutorado em Ciências) - Escola de Engenharia de Lorena, Universidade de São Paulo, Lorena, 2019.

\section{RESUMO}

Os polímeros têm apresentado um consumo crescente na indústria para a produção de diversos bens de consumo, principalmente para a fabricação de produtos descartáveis, que pode envolver a combinação de polímeros com outros materiais. Os processos de fabricação destes materiais levam a uma produção enorme de resíduos poliméricos pós-industriais. A reciclagem mecânica destes tipos de resíduos representa uma boa alternativa, associando o gerenciamento de resíduos sólidos com a pesquisa e inovação, permitindo conciliar interesses econômicos com os benefícios ambientais, viabilizando o desenvolvimento sustentável. No entanto, a separação dos polímeros dos resíduos constituídos por materiais combinados não é um processo simples e acarreta em desafios consideráveis. Desse modo, o objetivo do presente estudo foi pesquisar alternativas para a reciclagem mecânica de resíduos de filmes poliméricos multicamadas combinados com outros materiais. Para o desenvolvimento da pesquisa foram utilizados resíduos da fabricação de adesivos curativos. Estes materiais foram inicialmente caracterizados por meio de técnicas microscópicas, químicas, térmicas e análises mecânicas e submetidos a processamentos mecânicos e termomecânicos para a separação de componentes e reciclagem mecânica do material. Os resultados mostraram que os resíduos são compostos por uma fração de celulose e polímeros tais como polietileno (PE) e copolímeros. A separação e recuperação da celulose para todos os resíduos foi possível por meio de um processo simples e viável de hidropolpação, enquanto a porção polimérica dos resíduos pode ser incorporada a resíduos pós-industriais de polietileno de baixa densidade em até $20 \%$ em massa sem alterar significativamente propriedades mecânicas do material. Desta forma, a reciclagem mecânica dos resíduos apresenta condições técnicas de ser realizada.

Palavras-chave: Resíduos poliméricos pós-industriais. Filmes poliméricos. Reciclagem mecânica. Desenvolvimento sustentável. 
BRANCO, L. T. P. Study of alternatives for mechanical recycling of industrial polymeric wastes combined with other materials. 2019. 95p. Thesis (Doctoral of Science) - Escola de Engenharia de Lorena, Universidade de São Paulo, Lorena, 2019.

\begin{abstract}
Polymers have been showing an increasing consumption in the industry for the production of various consumer goods, mainly for the manufacturing of disposable products that can involve the combination of polymers with other materials. The industrial processes of these materials lead to a huge production of post-industrial waste. The mechanical recycling of these kinds of wastes represents a good alternative, associating the waste management with research and innovation, allowing the conciliation of economic interest with environmental benefits, enabling this way, a sustainable development. However, the separation of polymeric materials from these combined wastes is not so easy and entails considerable challenges. This way, the objective of this current study was to research alternatives for the mechanical recycling of multilayer polymeric film wastes combined with other materials. For the development of this research post-industrial wastes of curative adhesive were used. These materials were initially characterized by means of microscopy, chemical and thermal techniques and subsequently submitted to mechanical and thermomechanical processes for the separation of components and mechanical recycling of the material. The results showed that the wastes are composed of a fraction of cellulose and polymers, such as polyethylene (PE) and copolymers. The separation and recovery of cellulose for all residues was possible via simple and viable process of hydropulping, while the polymeric portion of residues can be incorporated into post industrial waste of polyethylene low density up to $20 \mathrm{wt} \%$ without sigfinificantly change the mechanical properties of the material.
\end{abstract}

Keywords: Post-industrial polymeric wastes. Polymeric films. Mechanical recycling. Sustainable development. 


\section{LISTA DE FIGURAS}

Figura 1 - Reciclagem mecânica no ciclo de vida dos polímeros sintéticos.................25

Figura 2 - Aplicação de curativo adesivo sensível à pressão.....................................29

Figura 3 - Identificação dos materiais: a) Curativo Adesivo Bege Escuro (CABE); b) Curativo Adesivo Bege Claro (CABC); c) Curativo Adesivo Bege Rosado (CABR) e d) Curativo Adesivo Transparente (CAT). 32

Figura 4 - Fluxograma dos procedimentos experimentais realizados na execução do projeto. .34

Figura 5 - Método utilizado para as análises do DSC. 36

Figura 6 - Dimensões do corpo de prova para o ensaio de tração. 41

Figura 7 - Dimensões do corpo de prova para o ensaio de impacto. 41

Figura 8 - Imagem do filme multicamada do resíduo CABE .44

Figura 9 - Imagem do filme multicamada do resíduo CABC.....................................44

Figura 10 - Imagem do filme multicamada do resíduo CABR ....................................45

Figura 11 - Imagem do filme multicamada do resíduo CAT .........................................45

Figura 12 - llustração da composição do resíduo de curativo 46

Figura 13 - Espectros de FTIR das camadas 1 e 2 para os resíduos CABE, CABC, CABR e CAT.

Figura 14 - Espectros de FTIR das camadas 3 e 4 para os resíduos CABE, CABC, CABR e CAT. 48

Figura 15 - Espectros de FTIR da camada 3 para os resíduos CABC e CAT. 49

Figura 16 - Espectros de FTIR das referências padrão Celulose, PEBD, PP e EVA...49 Figura 17 - Curvas de DSC das camadas 1 e 2 para os resíduos CABE, CABC, CABR e CAT: a) primeiro aquecimento e b) segundo aquecimento.

Figura 18 - Curvas de DSC das camadas 3 e 4 para os resíduos CABE, CABC, CABR e CAT: a) primeiro aquecimento e b) segundo aquecimento. .56

Figura 19 - Curvas de DSC das camadas 3 e 4 dos resíduos CABC e CAT: a) curvas do primeiro aquecimento camada 3, b) curvas do segundo aquecimento camada $3, \mathrm{c}$ ) curvas do primeiro aquecimento camada 4 e d) curvas do segundo aquecimento camada 4.

Figura 20 - Curvas de TGA das camadas 1 e 2: a) todos os resíduos; b) CABE com a curva derivada; c) CABC com a curva derivada; d) CABR com a curva derivada; e) CAT com a curva derivada. 
Figura 21 - Curvas de TGA das camadas 3 e 4 de todos os resíduos: a) todos resíduos; b) CABE com a curva derivada; c) CABC com a curva derivada; d) CABR com a curva derivada; $\quad$ e) $\quad$ CAT com a curva derivada.

Figura 22 - Curvas de TGA da camada 3 dos resíduos: a) resíduos CABC e CAT; b) CABC com a curva derivada; c) CAT com a curva derivada...

Figura 23 - Resultados de DMA dos resíduos CABC, CABE CABR e CAT: a) módulo de armazenamento: E'; b) módulo de perda: E" e c) fator de perda: Tan $\delta$ 64 Figura 24 - Teor de celulose recuperada e dos residuais, após o processo de hidropolpação dos resíduos: a) celulose recuperada e b) polímeros residuais . .66

Figura 25 - Imagem da celulose recuperada. .66

Figura 26 - Imagens dos resíduos em frente e verso: a) antes do processo de hidropolpação e b) após o processo de hidro-polpação.

Figura 27 - Resíduos poliméricos após a moagem: a) CABE; b) CABC; c) CABR e d) CAT 68

Figura 28 - Resíduos após extrusão e peletização: a) CABE extrudado e CABE peletizado; b) $C A B C$ extrudado e CABC peletizado; c) CABR extrudado e CABR

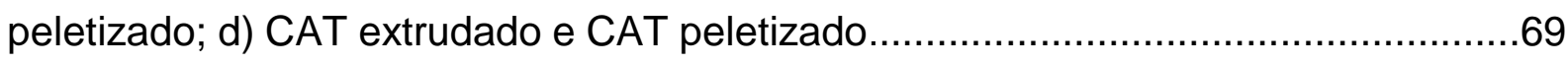

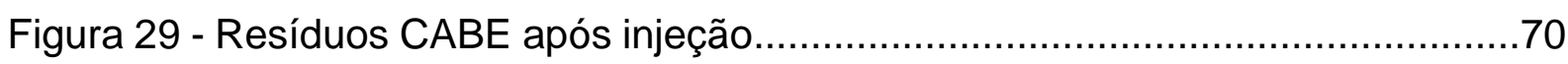

Figura 30 - Espectro de FTIR (ATR), das camadas dos filmes poliméricos do resíduo CABE. .71

Figura 31 - Curvas de DSC do resíduo CABE... 73

Figura 32 - Curva de TGA do resíduo CABE com a derivada após o procedimento por injeção.

Figura 33 - Imagens de MEV do resíduo CABE em ampliação de 40 vezes: a) região periférica e b) da região central.

Figura 34 - Imagens de MEV do resíduo CABE: a) região central (x 250); e da região periférica b) (x 200); c) (x 5000) e d) (x 10000). .76

Figura 35 - Resultado de DMA do resíduo CABE: a) módulo de armazenamento: E'; b) módulo de perda: E" e c) fator de perda: Tan $\delta$. .77

Figura 36 - Curvas de tensão-deformação dos oitos corpos de prova do resíduo CABE.

Figura 37 - Imagem dos corpos de prova do resíduo CABE após ensaio de tração...80 
Figura 38 - Imagens de corpos de prova do resíduo CABE utilizados no ensaio de resistência ao impacto Izod: a) antes do ensaio e b) após o impacto. Figura 39 - Imagens dos corpos de prova moldados: a) Padrão; b) CABE 10 e 15\%; c) $C A B C 10,15$ e 20\%; d) CABR 10, 15 e 20\%; e) 10, 15 e $20 \%$ 82

Figura 40 - Resistência à tração das blendas PEBD pós-industrial com resíduos políméricos dos curativos adesivos: CABE (--); CABC (-o-); CABR (- - -) e CAT (- - ) 83

Figura 41: Módulo de Young das blendas PEBD pós-industriais com resíduos poliméricos dos curativos adesivos: CABE (--); CABC (-o-); CABR (- $\Delta-)$ e CAT (- ). 84

Figura 42: Alongamento na ruptura das blendas $P E B D$ pós-consumo com resíduos polímeros dos adesivos curativos: CABE (--); CABC (-o-); CABR (- $\Delta-)$ e CAT (- $\diamond-$ ) ... .85

Figura 43: Resistência ao impacto das blendas PEBD pós-consumo com resíduos polímeros dos adesivos curativos: CABE (--); CABC (-o-); CABR (- $\Delta-)$ e CAT (- -$)$ )...86 


\section{LISTA DE TABELAS}

Tabela 1 - Monômeros acrílicos para adesivos curativos...........................................28

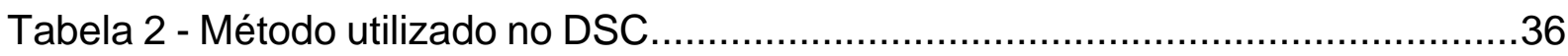

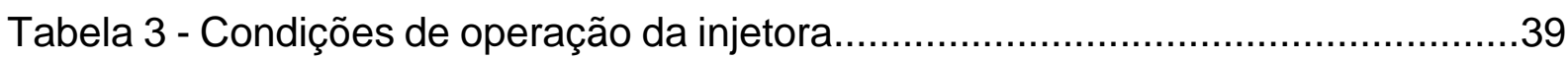

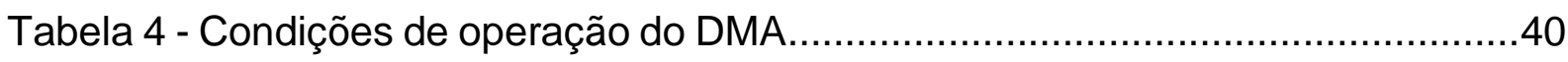

Tabela 5 - Bandas de FTIR dos resíduos em suas respectivas camadas.................50

Tabela 6 - Resultados de DSC das camadas poliméricas de resíduos........................57

Tabela 7 - Resultados de TGA das camadas poliméricas de cada resíduo.................63

Tabela 8 - Resultados de FTIR das camadas poliméricas do resíduo CABE.............72 



\section{SUMÁRIO}

1 INTRODUÇÃO

2 OBJETIVOS

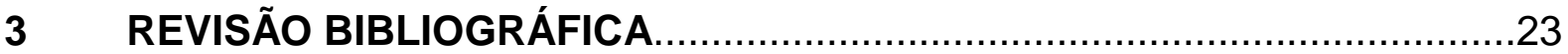

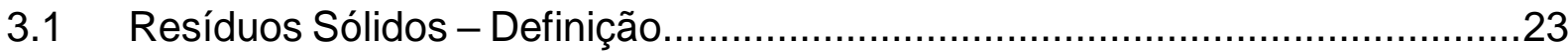

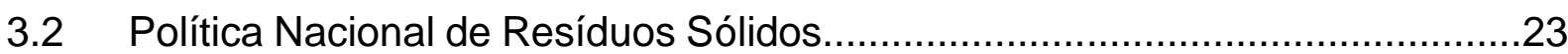

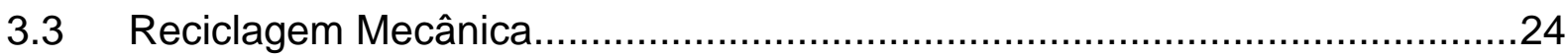

3.4 Reciclagem de Polímeros Combinados com Outros Materiais........................25

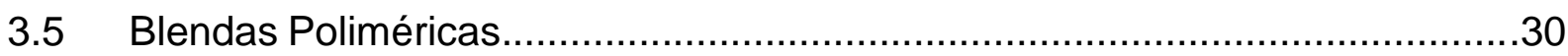

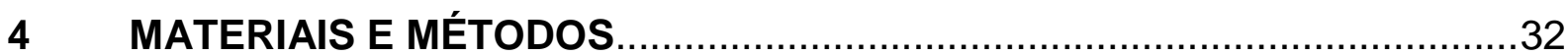

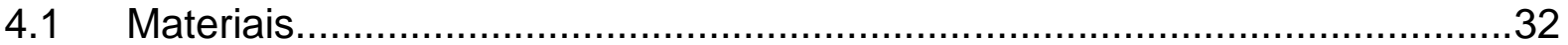

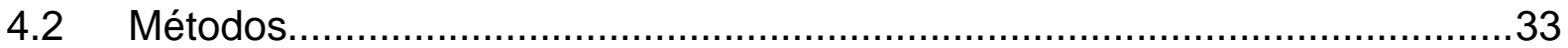

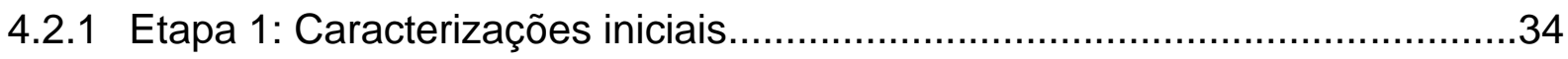

4.2.2 Etapa 2: Processamento dos resíduos e separação da celulose.......................37

4.2.3 Etapa 3: Caracterizações dos materiais após processamento.........................39

4.2.4 Etapa 4: Reciclagem dos materiais na forma de blendas poliméricas.............42

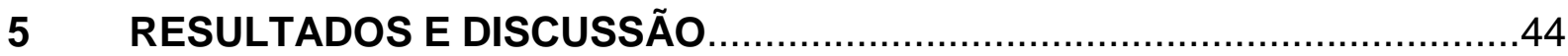

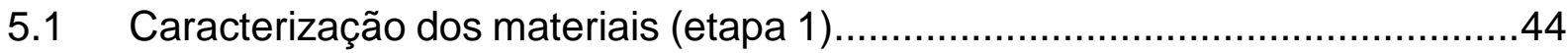

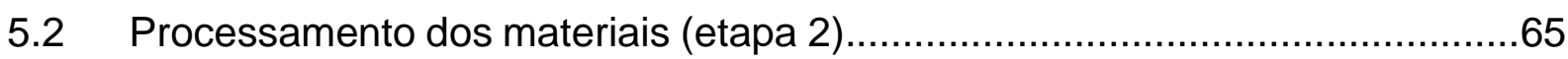

5.3 Caracterização dos materiais (etapa 3)...................................................

5.4 Reciclagem dos resíduos na forma de blendas poliméricas (etapa 4).............81

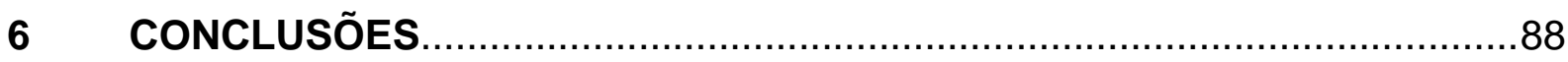

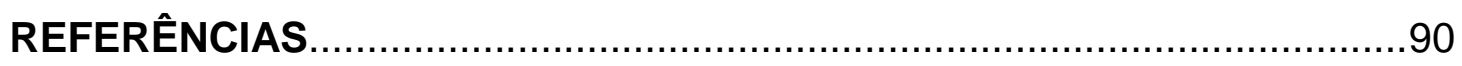





\section{INTRODUÇÃO}

Nas últimas décadas, o consumo de materiais poliméricos tem aumentado, gerando cada vez mais resíduos pós-industriais e pós-consumo, acentuando consequentemente o seu potencial poluidor ${ }^{(1)}$. Em 1964 foram produzidas 15 milhões de toneladas de polímeros, enquanto em 2014 a produção chegou a 311 milhões de toneladas, progredindo para 335 milhões de toneladas em 2016 e atingindo 348 milhões de toneladas em 2017 (2).

O aumento do consumo dos materiais poliméricos pode ser explicado pelas suas várias propriedades de interesse como baixa densidade, propriedades mecânicas adequadas para muitas aplicações, baixo custo e também pelo fato que a população mundial deve alcançar 9,7 bilhões de pessoas até 2050, um aumento expressivo considerando que a população mundial atual é de 7,3 bilhões (3,4,5,6,7). Com a necessidade das pessoas adotarem novos padrões de consumo no sentido de gerar melhoria de qualidade de vida, há um aumento considerável no consumo de polímeros, em função da infinidade de aplicações dos polímeros em diversas áreas como de eletrodomésticos, embalagens, construção, medicina, eletrônica e componentes automotivos e aeroespaciais ${ }^{(6)}$. Os materiais poliméricos podem ser usados como fibras, polímeros flexíveis, polímeros rígidos ou elastômero em diversos tipos de produtos como por exemplo, as roupas, os filmes de embalagens, as lentes de contato e os pneus. Os materiais poliméricos mais usados em produções de baixo custo são chamados plásticos ou resinas commodities, sendo os principais: polietileno $(\mathrm{PE})$, polipropileno (PP), poliestireno (PS), poli (cloreto de vinila) (PVC) e o poli (tereftalato de etileno) (PET) ${ }^{(4,8)}$.

Em adição a isso, tem-se o desenvolvimento de várias vias de produção de polímeros derivados de fontes petroquímicas que contribuem para um relevante incremento das indústrias do setor e o aumento no consumo de polímeros em diversos segmentos ${ }^{(1,7)}$.

Desse modo, o crescente consumo de materiais poliméricos é irreversível e isso leva consequentemente a um aumento de seus resíduos. A maioria dos polímeros fabricados atualmente não é biodegradável podendo existir resíduos sólidos desses materiais no meio ambiente por séculos, se não milênios ${ }^{(1,6,8,9)}$. 
O termo "desenvolvimento sustentável" refere-se ao conceito de desenvolver-se para atender as atuais necessidades sem comprometer a capacidade de desenvolvimento das futuras gerações ${ }^{(10)}$. O desenvolvimento sustentável pode ser alcançado com o gerenciamento adequado dos recursos naturais por meio da redução de resíduos, do reuso de produtos e materiais e da reciclagem de materiais (11). Segundo Hamad e colaboradores (2013), a reciclagem de polímeros é a maneira mais adequada para reduzir os problemas ambientais causados pelo acúmulo de resíduos poliméricos gerados a partir da produção de bens de consumo constituídos destes materiais que estão presentes no nosso dia a dia (6).

Reciclar é uma estratégia de gestão de resíduos, que pode ser entendida como um modelo do conceito de ecologia industrial, em que se tem a recuperação de um material para a fabricação de um novo produto ${ }^{(7)}$.

A reciclagem é um método necessário não somente para reduzir os danos causados ao meio ambiente, mas também para reduzir o esgotamento dos recursos naturais, diminuindo a energia e os materiais usados e assim melhorando a ecoeficiência, que é uma ação que leva ao desenvolvimento sustentável, além dos benefícios sociais e econômicos ${ }^{(7,12)}$.

O processo de reciclagem permite que o consumo da matéria-prima seja reduzido, além de possibilitar que os resíduos voltem ao processo produtivo, tornando o ciclo produtivo renovável. Este processo pode ser realizado de diferentes formas por meio da reciclagem mecânica (primária ou secundária), química (terciária) e energética (quaternária) ${ }^{(5,6)}$.

Pode-se refletir sobre o conceito dos $4 \mathrm{Rs}$ dentro da estratégia de gestão de resíduos, da seguinte forma: redução dos materiais, reuso dos materiais, reciclagem dos materiais e recuperação da energia, e como última opção nessa estratégia de gestão de resíduos estaria o aterro dos materiais ${ }^{(7)}$.

Em consequência do crescente consumo desses materiais, o desenvolvimento sustentável se faz muito importante oferecendo solução para os problemas gerados pelos resíduos. Neste sentido, investimentos em pesquisa e desenvolvimento de novas tecnologias de reciclagem são necessários, bem como ações para a conscientização quanto ao consumo e ao descarte dos materiais poliméricos $(1,7,13)$. 
Além do uso crescente na produção de diversos bens de consumo, os polímeros ganharam destaque na fabricação de produtos descartáveis. E para esses produtos terem características desejáveis conforme sua aplicação, os polímeros normalmente são combinados com outros materiais por meio de processo de laminação ou coextrução, originando uma única estrutura, um filme multicamada, com propriedades químicas, físicas e mecânicas especiais, que dificilmente são encontradas em um único material. No entanto, a separação dos polímeros dos outros materiais não é um processo tão simples e acarreta desafios consideráveis para a gestão desses resíduos (14).

Em consequência deste crescente consumo, a indústria de polímeros atravessa atualmente um período de transformações, tanto em seu processo produtivo quanto em suas aplicações, gerando muitos desafios, mas muitas oportunidades também. Em função das novas necessidades do mercado, toda sua concepção tem sido questionada e repensada. Desta forma, todos os desafios que envolvem estas transformações para uma produção mais consciente e sustentável vem sendo estudada de forma sistêmica e criteriosa, a fim de encontrar soluções concretas e viáveis para a indústria e para o meio ambiente. Para que estas transformações ocorram de forma correta, é preciso envolver toda a cadeia de mercado dos polímeros que compreeende transformadores, recicladores, indústria de bens de consumo, cooperativas, varejo, petroquímicas e gestores de resíduos, abrangendo consumidores e poder público para assim atender todas as necessidades industriais e ambientais (12).

Dessa forma, a alternativa mais adequada para o tratamento destes resíduos é por meio da reciclagem, a qual pode, inclusive, converter custos em ganhos reais para as empresas que trabalham com estes materiais e que têm cada vez mais sentido a necessidade de buscar alternativas para os resíduos poliméricos que são produzidos e descartados em aterros sanitários, seja pelos custos crescentes desta ação ou por pressões da legislação ambiental, cada vez maiores. Entretanto, a viabilidade do processo de reciclagem somente pode ser alcançada com o desenvolvimento de técnicas e metodologias adequadas para este fim. Sendo assim, o presente projeto teve como finalidade o estudo de métodos para viabilizar a reciclagem mecânica de resíduos pós-industrial de filmes poliméricos de composição variada em combinação com outros materiais. 


\section{OBJETIVOS}

O objetivo deste trabalho foi pesquisar uma alternativa, para a reciclagem mecânica de resíduos pós-industriais gerados durante o recorte de filmes multicamadas compostos por polímeros combinados com outros materiais para a fabricação de adesivos curativos.

Para isto, foram traçados objetivos específicos, que estão divididos em quatro etapas de desenvolvimento experimental:

a) Primeira etapa: caracterização dos resíduos para avaliar a sua composição e suas propriedades térmicas;

b) Segunda etapa: avaliação da viabilidade de processos de separação da celulose dos outros componentes poliméricos e da processabilidade do material por métodos termomecânicos;

c) Terceira etapa: caracterizações após processamento dos materiais para avaliar a composição final, as propriedades térmicas, reológicas e mecânicas desses materiais;

d) Quarta etapa: estudo de alternativas para viabilizar o processamento termomecânico e a reciclagem mecânica da fração de polímeros sintéticos remanescente após remoção da celulose do resíduo, de modo a alcançar a reciclagem completa do material. 


\section{REVISÃO BIBLIOGRÁFICA}

\subsection{Resíduos Sólidos - Definição}

Conforme a NBR 10.004, da Associação Brasileira de Normas Técnicas - ABNT, a definição para resíduos sólidos é:

"Resíduos nos estados sólido e semi-sólido, que resultam de atividades de origem industrial, doméstica, hospitalar, comercial, agrícola, de serviços e de varrição. Ficam incluídos nesta definição os lodos provenientes de sistemas de tratamento de água, aqueles gerados em equipamentos e instalações de controle de poluição, bem como determinados líquidos cujas particularidades tornem inviável o seu lançamento na rede pública de esgotos ou corpos de água, ou exijam para isso soluções técnica e economicamente inviáveis em face à melhor tecnologia disponível." (15)

\subsection{Política Nacional de Resíduos Sólidos}

A Lei Federal no 12.305/10, que institui a Política Nacional dos Resíduos Sólidos (PNRS), dispõe dentre as suas diretrizes, a gestão integrada e o gerenciamento de resíduos sólidos, com o intuito de reduzir o volume total desses resíduos que são produzidos nacionalmente. Essa política tem como um dos princípios o desenvolvimento sustentável que pode estar aliado à iniciativa de incentivo ao desenvolvimento de sistemas de gestão ambiental e empresarial voltados para a melhoria dos processos produtivos e ao reaproveitamento dos resíduos sólidos, incluindo a recuperação e o aproveitamento energético (16).

Além disso, a PNRS apresenta no art. 6으, o princípio da responsabilidade compartilhada pelo ciclo de vida dos produtos, no qual todos os envolvidos tanto na fabricação quanto no consumo de produtos são solidariamente responsáveis pela administração dos resíduos que são gerados, fazendo com que o princípio do desenvolvimento sustentável seja gerido de forma mais eficaz ${ }^{(17)}$. 


\subsection{Reciclagem Mecânica}

A reciclagem primária e secundária, são conhecidas como reciclagem mecânica, a primária utiliza polímero pós-industrial e a secundária utiliza polímero pós-consumo. Esta representa uma boa alternativa para a reciclagem dos resíduos poliméricos, permitindo aliar o interesse econômico com os benefícios ambientais, por meio do uso inteligente das matérias-primas e da expansão do ciclo de vida dos materiais e produtos, podendo obter um novo material polimérico sem que haja a necessidade de síntese de novos polímeros e favorecendo o desenvolvimento sustentável $(1,18,19,20)$.

Nesse tipo de reciclagem são necessárias algumas etapas que incluem a separação do resíduo polimérico, moagem, lavagem, secagem, reprocessamento e por fim a obtenção de um novo material polimérico. Podem existir variações nessas etapas em função do tipo de polímero e da sua procedência e em relação também aos equipamentos utilizados ${ }^{(19)}$.

No Brasil a reciclagem mecânica é a mais usada, quando comparada as reciclagens química e energética, em função dos baixos custos com o investimento em instalação para esse tipo de reciclagem, do crescente volume de polímeros produzidos e do custo de mão-de-obra. Tem sido notado que a qualidade dos produtos obtidos por meio da reciclagem mecânica vem aumentando também, devido à melhoria dos processos ${ }^{(19,20)}$. Conforme trabalho de Hamad e colaboradores (2013), pode ser considerado, na reciclagem mecânica, a incorporação de polímeros virgens do mesmo tipo de polímero ou de outros polímeros na presença de compatibilizantes adequados que podem resultar em boas propriedades mecânicas e na estabilidade térmica ${ }^{(6)}$.

Além disso, a qualidade dos produtos obtidos se deve também a uma eficaz separação do polímero do material não polimérico (21).

A reciclagem mecânica pode ser considerada um método estratégico para o gerenciamento de resíduos, pois apresenta menor impacto ambiental, menor emissão de gases que contribuem para o aquecimento global, é menos dispendiosa e apresenta um menor consumo de energia, quando comparada aos outros tipos de reciclagem. Além de ser um método de reciclagem mais apropriado para reciclar resíduos em grandes quantidades, oferecendo também uma maior confiabilidade e expansão do ciclo de vida dos materiais e produtos ${ }^{(6,7,20,22,23)}$. A Figura 1 ilustra a etapa de reciclagem mecânica no ciclo de vida dos polímeros sintéticos. 
Figura 1 - Reciclagem mecânica no ciclo de vida dos polímeros sintéticos.

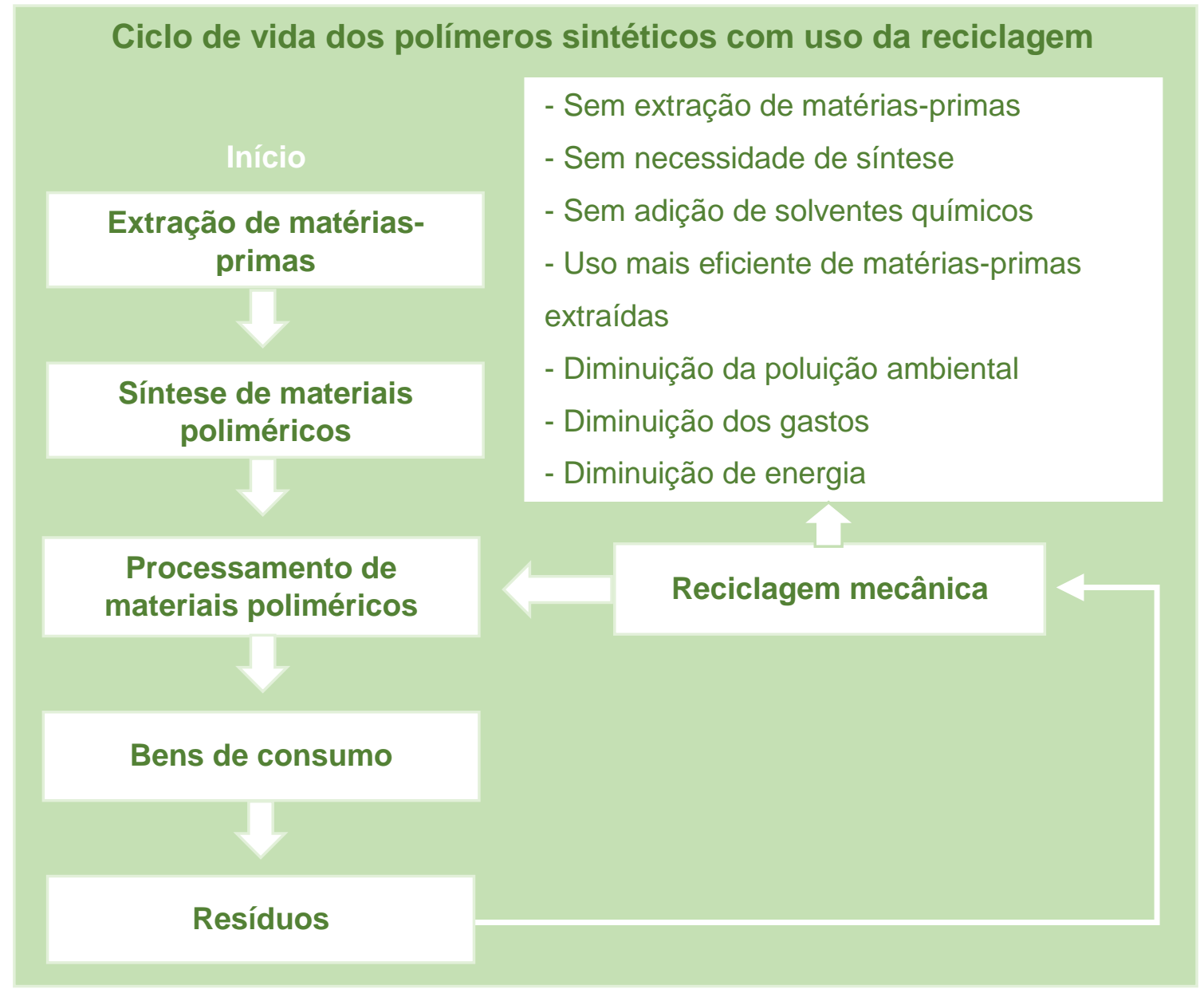

Fonte: própria do autor.

\subsection{Reciclagem de Polímeros Combinados com Outros Materiais}

A etapa da separação de macro contaminantes como a celulose, metal, compostos orgânicos e outros polímeros é muito importante para limitar a presença destes a níveis inferiores a $1 \%$ em massa na reciclagem, quando se tem interesse em obter um produto reciclado com as propriedades mais próximas possíveis do produto original produzido com polímero virgem, pois mesmo em pequenas concentrações as propriedades do polímero podem ser alteradas em função da presença de impurezas. É importante ressaltar que existem processos que foram desenvolvidos para a reciclagem de resíduos de polímeros misturados com macro-contaminantes, admitindo em torno de 30 a 40\% em massa do contaminante por polímeros não fundido, para a geração de um novo produto diferente do original, mas com grande interesse econômico também ${ }^{(19)}$. Dentre esses resíduos de polímero combinados com 
outros materiais, existem os filmes multicamadas, que são formados por materiais como polietileno, polipropileno, poliamidas, poliésters, papel, alumínio, entre outros (24). Na prática, a separação desses materiais é dificilmente realizada, por causa das várias camadas poliméricas finas que estão laminadas juntamente com o alumínio, celulose e outros materiais, dificultando ainda mais o processo de reciclagem ${ }^{(25)}$.

Como exemplo de produtos fabricados com filmes multicamadas tem-se as embalagens TetraPak $^{\circledR}$, que é uma das embalagens de bebida e alimentos líquidos mais usadas no mundo. Essa embalagem é constituída por três tipos de matérias primas: celulose, em torno de $75 \%$; polietileno de baixa densidade, cerca de $20 \%$ e alumínio, aproximadamente 5\% em massa. Umas das propriedades interessantes da embalagem TetraPak $^{\circledR}$, consiste em permitir o armazenamento de alimentos por longo período de tempo sem refrigeração, seis meses ou mais. A grande demanda de uso para esse tipo de embalagem gera uma quantidade significante de resíduos que podem ser reciclados com o uso da técnica de hidro-polpação, exemplo bem-sucedido para reciclagem de polímeros combinados com outros materiais ${ }^{(26,27)}$. Esse processo envolve a separação das fibras de celulose das finas camadas de polietileno e do alumínio. As fibras de celulose separadas são usadas na fabricação de produtos à base de celulose e o compósito matriz polimérica/alumínio é utilizado para muitas outras aplicações ${ }^{(26,27)}$. Um estudo realizado por Korkmaz e colaboradores (2009), mostra que as porcentagens em massa da recuperação dos diversos materiais a partir da reciclagem das embalagens TetraPak ${ }^{\circledR}$ pode atingir $63 \%$ para a celulose, $30 \%$ para o polietileno e $7 \%$ para o alumínio (27).

O processo de hidro-polpação é um processo simples, que não necessita da utilização de aditivos, consistindo em misturar o material a ser reciclado em água sob constante agitação. Durante esse processo as fibras de celulose são separadas das finas camadas de polímeros e permanecem suspensas em água. A remoção final da celulose é feita por meio de centrifugação da suspensão aquosa com subsequente secagem do material. A separação das fibras de celulose dos filmes poliméricos ocorre pela força da agitação mecânica, pois quando a força aplicada às camadas das fibras é mais forte do que as ligações entre as fibras, a camada de celulose irá romper em pedaços menores e eventualmente em fibras individuais. O processo de agitação mecânica é facilitado pela natureza hidrofílica da celulose, bem como pela correta adequação da velocidade de rotação com o tamanho das palhetas do misturador, que combinados são muito relevantes nesse processo de separação ${ }^{(28,29,30,31,32)}$. Em 
adição a isso, Cho e colaboradores (2009), ressaltam a importância da água penetrar na camada da celulose para promover a clivagem das ligações de hidrogênio entre as fibras e assim levar a despolpa da celulose. A penetração da água é fortemente influenciada pela estrutura dos poros e a hidrofobicidade da superfície e do meio poroso da celulose, o qual pode ser afetado levando em consideração o tipo de polpa de celulose, virgem ou recuperada, e se recuperada o tipo de recuperação da celulose e sua composição (de celulose nova ou velha), que foi utilizada no filme multicamada, pois esse é um dos fatores que mais influenciam na taxa de despolpa da celulose. Se a celulose utilizada é impressa e revestida por outro material com natureza hidrofóbica ela se torna mais resistente à sua despolpa, pois esse revestimento influencia na resistência à umidade da celulose ${ }^{(32)}$.

Além da indústria de embalagem TetraPak ${ }^{\circledR}$, há a indústria de adesivos sintéticos, que é um outro ramo industrial muito importante também nos dias de hoje, devido à sua ampla abrangência, atendendo às indústrias de saúde, higiene, cosmética, automotiva e dentre outras, produzindo adesivos compostos de filmes multicamadas de polímeros, podendo esses serem combinados com outros materiais, como por exemplo a celulose.

Os curativos sensíveis à pressão, compostos de polímeros laminados junto com a celulose (Figura 2), são exemplos de filmes multicamadas muito utilizados nos últimos anos na área da saúde ${ }^{(17)}$. Segundo um trabalho de Kenney e colaboradores (1992), é relatado que os adesivos médicos sensíveis à pressão, são tradicionalmente produzidos a partir de formulações de borracha natural, mas atualmente com o intuito de diminuir a irritação na pele esses adesivos estão sendo produzidos mais frequentemente a partir de polímeros acrílicos, sintetizados a partir de monômeros como o acrilato de 2-etilhexila, acrilato de isooctila ou $n$-butila acrilato copolimerizados com monômeros funcionais polares, tais como o ácido acrilato, ácido metacrílico, acetato de vinila, acrilato de metila, $N$-vinil caprolactama ou metacrilato de hidroxietila, conforme mostrado na Tabela $1^{\left({ }^{(3)} \text {. }\right.}$ 
Tabela 1 - Monômeros acrílicos para adesivos curativos.

\begin{tabular}{ll}
\hline Hidrofóbicos & Hidrofílicos \\
\hline Acrilato de 2-etil hexila & Ácido acrílico \\
Acrilato de isooctila & Ácido metacrílico \\
Acrilato de n-butila & Acetato de vinila \\
& Acrilato de metila \\
& $N$-vinil caprolactama \\
& Metacrilato de hidroxietila \\
\hline
\end{tabular}

Fonte: (33).

Além do mais, a presença de comonômeros funcionais nos adesivos médicos sensíveis à pressão aumenta a força coesiva, promove a polaridade da superfície, e aumenta a resistência ao desgaste. Em adição a isso, a massa molar, a temperatura de transição vítria ( $\mathrm{Tg}$ ) e o comportamento visco-elástico do adesivo determinam a aderência, adesão e transferência do adesivo para a pele e o desempenho de sua resistência ao desgaste ${ }^{(33)}$. Os adesivos poliméricos são feitos a partir de dois ou mais monômeros para alcançar as propriedades viscoelásticas necessárias, sendo preciso um monômero hidrofóbico para copolimerizar com um ou mais monômeros hidrofílicos, de modo que uma grande quantidade de monômero hidrofóbico é incorporado para promover uma temperatura de transição vítrea ( $\mathrm{Tg}$ ) baixa e uma pressão sensível. Já os monômeros hidrofílicos estão presentes na composição para aumentar a força de coesão e promover uma superfície polar no adesivo ${ }^{(33)}$. A Figura 2 ilustra a aplicação do curativo adesivo sensível à pressão. 
Figura 2 - Aplicação de curativo adesivo sensível à pressão.

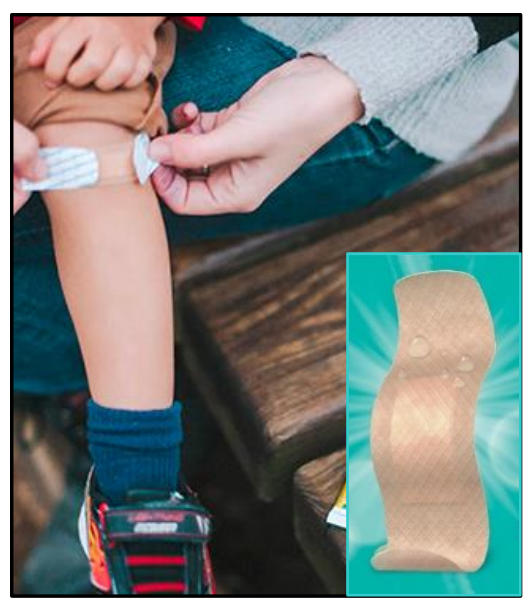

Fonte: (34).

A técnica de coextrusão, que é um método comum usado na produção de filmes multicamadas a partir de dois ou mais materiais diferentes que são extrudados e laminados juntos para formar uma única estrutura com múltiplas camadas ${ }^{(35)}$, é uma técnica que está sendo amplamente utilizada na fabricação de novos produtos na forma de finos filmes, e esses produtos são compostos geralmente de 3 a 9 camadas de polímeros diferentes e na grande maioria das aplicações, as camadas externas consistem em polímeros mais baratos, com função de barreira à água e com boas propriedades mecânicas. Já as camadas internas consistem em materiais mais elaborados e caros que oferecem boas propriedades de barreiras a gases (36). Consequentemente, os filmes poliméricos multicamadas combinados com outros materiais, como por exemplo a celulose, melhoram a performance de aplicação, e eles estão ganhando cada vez mais importância em diferentes setores industriais ${ }^{(37,38)}$.

Portanto, em consequência ao uso cada vez maior de filmes multicamadas na produção de diversos tipos de produtos, é gerada uma quantidade expressiva de resíduos pós-industriais durante o processo de recorte desses filmes na fabricação de produtos, que na maioria das vezes são descartáveis e apesar dos polímeros estarem vinculados à qualidade e performance desses produtos citados, eles acarretam em muitos danos e riscos ambientais em função da dificuldade de reciclar polímeros que estão combinados com outros materiais.

Portanto o uso deste processo de hidro-polpação e processos semelhantes são muito relevantes como uma etapa da reciclagem mecânica para a recuperação de materiais poliméricos. 


\subsection{Blendas Poliméricas}

As blendas poliméricas são misturas de dois ou mais polímeros, que apresentam várias propriedades em função de suas composições. Elas podem ser:

a) Miscíveis ou parcialmente miscíveis, quando há boa interação química entre os componentes da blenda;

b) Imiscíveis, quando há baixa interação química entre os componentes da blenda, resultando em fases distintas com interfaces definidas.

Nas blendas miscíveis não ocorre a separação de fase, formando um sistema monofásico. A miscibilidade também é definida pela União Internacional de Química Pura e Aplicada (IUPAC), como sendo "a capacidade de uma mistura em formar uma única fase em certas faixas de temperatura, pressão e composição". O contrário disso é observado nas blendas parcialmente miscíveis e imiscíveis que são heterogêneas, dependendo de fatores cinéticos e termodinâmicos ${ }^{(18,39)}$.

Na prática, as blendas poliméricas são, em sua grande maioria, imiscíveis. Assim o processamento termomecânico de filmes multicamadas pós-industriais durante a reciclagem mecânica, deve levar à formação de blendas imiscíveis, uma vez que estes filmes são baseados na combinação de polímeros que buscam agregar desempenho satisfatório de propriedades com baixo custo. O filme multicamada produzido a partir dos polímeros polietileno e poliamidas, é um exemplo, cujo reprocessamento leva à formação de uma blenda intrinsicamente imiscível. Vale ressaltar que a separação dos componentes poliméricos dos filmes multicamadas para a reciclagem mecânica é tecnicamente impraticável ou inviável economicamente.

Outro fator muito importante nas blendas poliméricas é a compatibilidade entre os seus componentes e segundo a IUPAC, uma blenda compatível é uma "blenda polimérica imiscível que exibe propriedades físicas de modo macroscopicamente uniforme em toda a sua extensão", logo esse termo: blenda compatível, nada mais é, que uma blenda macroscopicamente homogênea, sendo ela miscível ou não miscível $(18,40)$.

As blendas poliméricas imiscíveis podem apresentar um grande problema devido a interação interfacial ser muito fraca, podendo resultar em propriedades mecânicas deficientes, de baixa qualidade para atingir uma propriedade física desejável para uma determinada aplicação. Para melhorar a compatibilidade entre as fases imiscíveis na blenda, pode-se fazer o uso de compatibilizantes, os quais melhoram a adesão entre 
as fases, por meio da promoção de interações ou ligações químicas covalentes na região interfacial matriz/fase dispersa. É importante salientar que nem todas as blendas poliméricas imiscíveis precisam do uso de compatibilizantes, se estas apresentarem macroscopicamente uma homogeneidade ${ }^{(41)}$.

Segundo Vallim e colaboradores (2009), o uso de polímeros reciclados pode representar uma alternativa ao uso de compatibilizantes funcionais convencionais, devido à uma possível existência de grupos funcionais ao longo da cadeia que são gerados durante seu processo de envelhecimento, podendo, dessa forma promover interações favoráveis, auxiliando na formação de uma interfase entre os componentes da blenda, ou seja, reduzindo o tamanho médio dos domínios da fase dispersa e aumentando a área interfacial. Além de que, o uso de polímeros reciclados pode reduzir o custo da blenda, melhorar as propriedades mecânicas e reduzir o desperdício desses materiais ${ }^{(18,42)}$.

Em aplicações comerciais as blendas poliméricas podem ser utilizadas para reduzir custos de um termoplástico que envolve uma engenharia de alto custo ou para melhorar a sua processabilidade a altas temperaturas ou ainda, para melhorar a sua resistência ao impacto. Em adição a isso, as blendas têm se tornado cada vez mais importantes em relação ao baixo custo de produtos comerciais à base de materiais poliméricos ${ }^{(39)}$. Como uma prática industrial comum, tem-se o uso dos polímeros reciclados com polímeros virgens, quando verifica-se a mesma natureza ou composição e viscosidade semelhantes dos polímeros, para alcançar a melhor relação entre viabilidade econômica e propriedades finais do produto ${ }^{(43)}$.

Por permitirem a obtenção de novos produtos sem que haja a necessidade de síntese, as blendas poliméricas obtidas por meio da reciclagem são muito importantes para as indústrias, além de viabilizar o desenvolvimento sustentável $(1,12,44)$.

Portanto, as oportunidades de pesquisa são vastas em função das possibilidades que podem ocorrer entre os componentes de uma blenda ${ }^{(18)}$. 


\section{MATERIAIS E MÉTODOS}

\subsection{Materiais}

Os resíduos poliméricos pós-industriais utilizados no presente estudo foram fornecidos pela empresa americana Johnson\&Johnson do Brasil Indústria e Comércio de Produtos para a Saúde Ltda. Esses resíduos poliméricos são constituídos de retalhos de filmes multicamadas, compostos por diferentes polímeros combinados com a celulose. Esses resíduos são gerados durante o recorte na fabricação de curativos adesivos sensíveis à pressão e apresentam dimensões variadas. A Figura 3 , apresenta a foto dos quatro materiais em estudo, com suas respectivas identificações.

Figura 3 - Identificação dos materiais: a) Curativo Adesivo Bege Escuro (CABE); b) Curativo Adesivo Bege Claro (CABC); c) Curativo Adesivo Bege Rosado (CABR) e d) Curativo Adesivo Transparente (CAT).

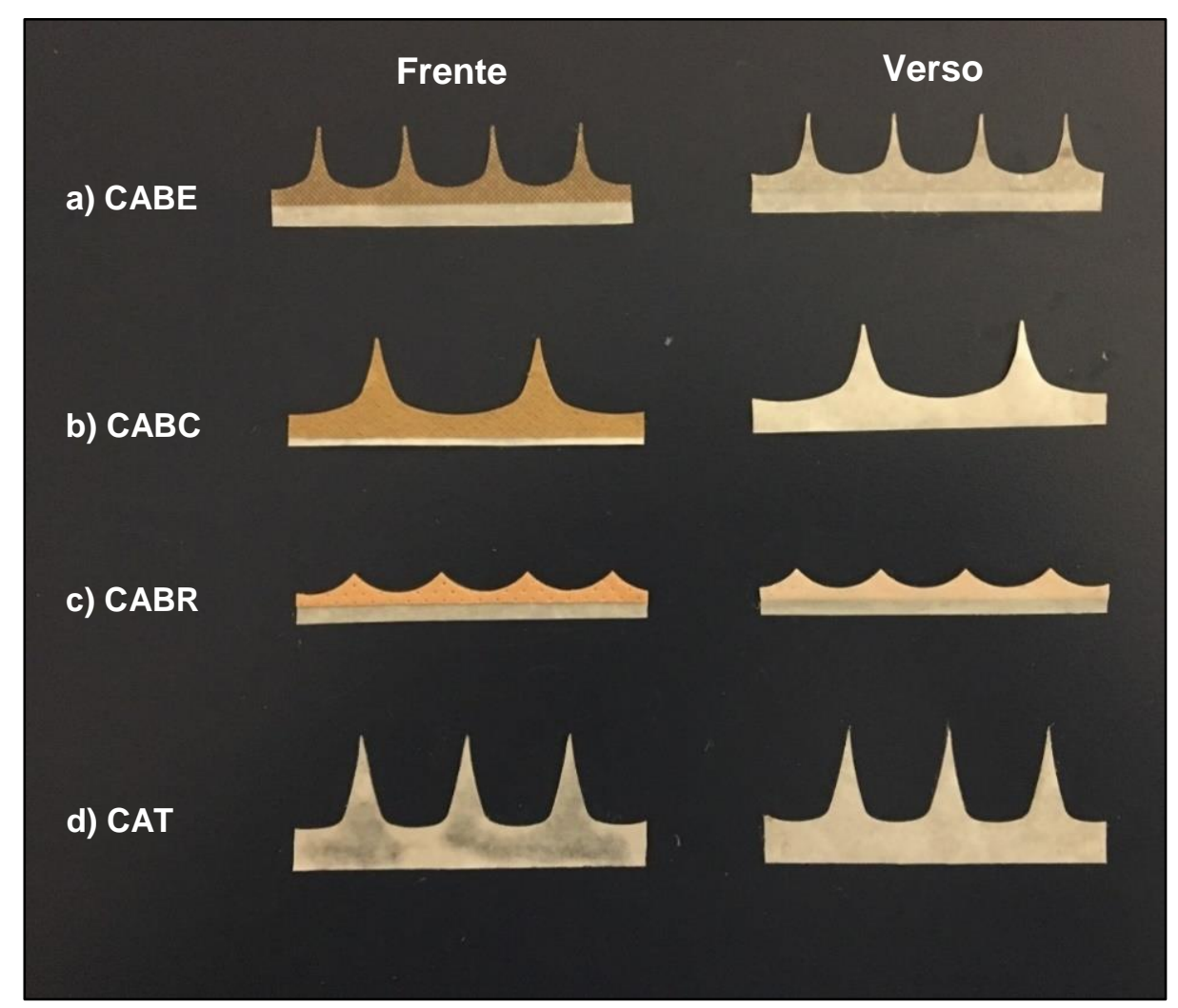

Fonte: própria do autor. 
Além destes quatro materiais, foi fornecido também, pela Me. Rayane Veloso de Camargo o resíduo pós-industrial de polietileno de baixa densidade peletizado, para ser utilizado na última etapa desta pesquisa, na produção de blendas poliméricas juntamente com os resíduos deste trabalho.

\subsection{Métodos}

O projeto foi desenvolvido em quatro etapas. A primeira etapa teve como finalidade caracterizar os materiais na forma em que foram fornecidos pela Johnson\&Johnson Brasil, para avaliar a estrutura física dos filmes e das suas respectivas camadas, composição polimérica, e propriedades térmicas destes materiais.

$\mathrm{Na}$ segunda etapa foi realizado o processamento dos materiais, utilizando a técnica de hidro-polpação para separar a celulose dos filmes poliméricos. $\mathrm{Na}$ sequência, os filmes foram moídos para gerar partículas em tamanho reduzidos e homogêneos para serem processados por extrusão e posterior moldagem por injeção para a preparação de corpos de prova de tração e impacto.

Já na terceira etapa foram realizadas caracterizações após o processamento dos resíduos para investigar a composição final, suas propriedades térmicas, reológicas e mecânicas desses materiais.

A quarta etapa do trabalho foi destinada a avaliar o potencial de reciclagem dos resíduos poliméricos dos filmes multicamadas como blendas com resíduos pósindustrial de polietileno de baixa densidade (PEBD).

A Figura 4, descreve de forma resumida o procedimento experimental de cada etapa desse projeto, incluindo as técnicas empregadas em cada etapa. 
Figura 4 - Fluxograma dos procedimentos experimentais realizados na execução do projeto.
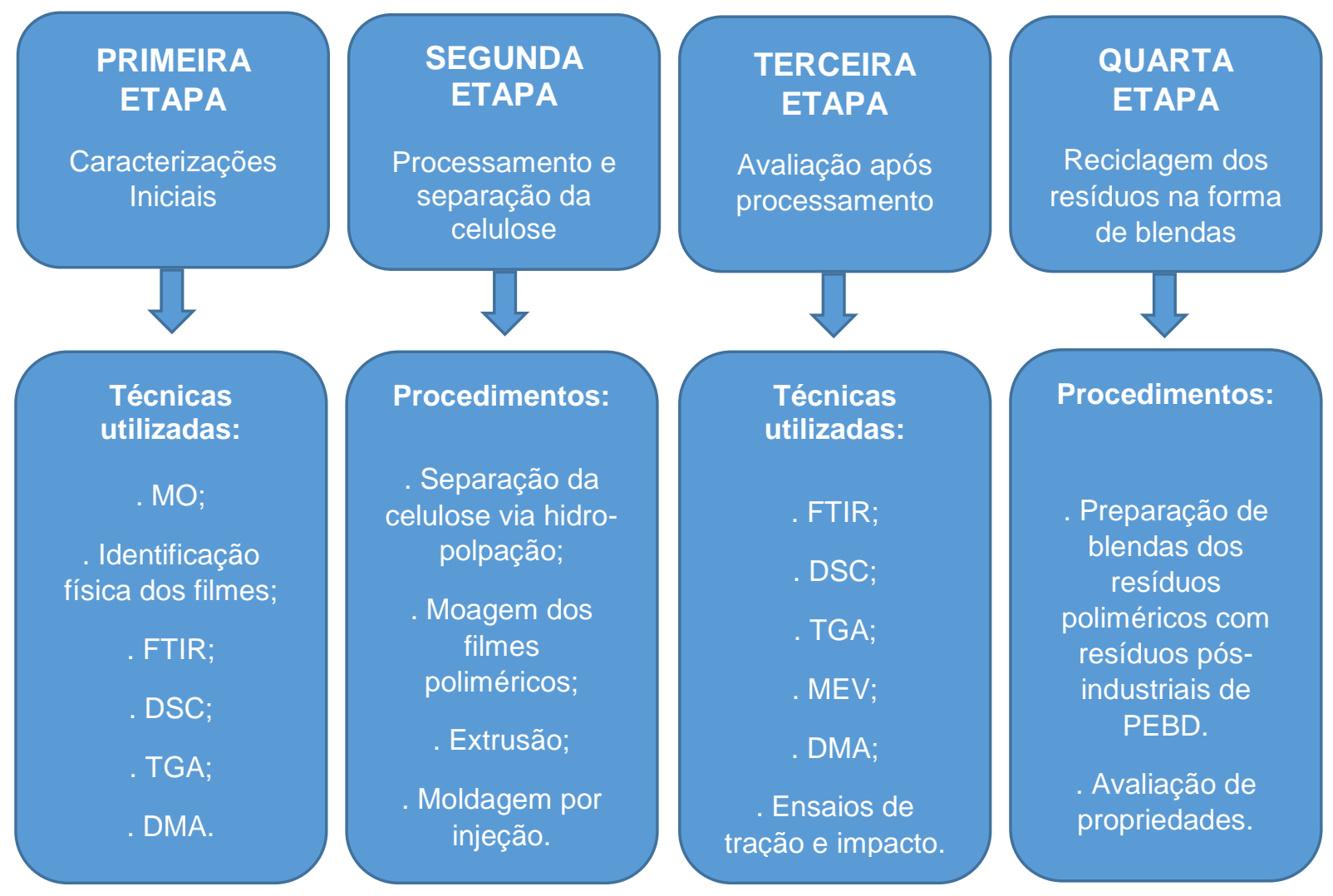

Procedimentos:

Preparação de

blendas dos

resíduos

poliméricos com

resíduos pós-

industriais de

PEBD.

Avaliação de

propriedades.

Fonte: Própria do autor.

\subsubsection{Etapa 1: Caracterizações iniciais}

\section{- Microscopia Ótica (MO)}

A microscopia ótica foi utilizada para avaliar as diferentes camadas que compõe a microestrutura dos resíduos poliméricos na forma de filmes. As imagens foram obtidas com um aumento de 100X, a partir de um estéreo microscópio da marca ZEISS e modelo Discovery $\mathrm{V}-12$, disponível no Departamento de Engenharia de Materiais (DEMAR) da EEL/USP.

Os materiais na forma de filme polimérico com celulose foram cortados criogenicamente, após imersão em nitrogênio líquido durante 5 minutos e com o auxílio de uma tesoura. Na sequência, cada resíduos foi colocado no meio de duas lâminas de vidro, as quais foram fixadas com auxílio de dois suportes, mantendo para todas os resíduos a celulose voltada para a parte superior durante a análise. A seção 
transversal de cada resíduo foi observada com um aumento de 100x, e na sequência foi feito a captura da imagem. Além da avaliação microscópica, as camadas dos filmes foram segregadas manualmente e analisadas visualmente com a finalidade de identificar o número de camadas distintas em camada filme. As imagens foram obtidas da região da fratura.

\section{- Espectroscopia no Infravermelho por Transformada de Fourier (FTIR)}

A técnica de FTIR foi conduzida com o propósito de determinar grupos químicos presentes nos filmes poliméricos. Os espectros foram obtidos em um espectrofotômetro da marca SHIMADZU modelo IR PRESTIGE-21, disponível DEMAR.

Os filmes poliméricos foram analisados pelo método de refletância total atenuada (ATR). Os resíduos foram preparados na forma de filme polimérico sem a celulose e analisados diretamente no dispositivo. A análise foi realizada no modo de transmitância, em um intervalo de $4500-600 \mathrm{~cm}^{-1}$, na resolução de $4 \mathrm{~cm}^{-1}$ e com 64 varreduras $(45,46)$.

\section{- Calorimetria Exploratória Diferencial (DSC)}

As análises de DSC foram realizadas para determinar as transições térmicas dos materiais. As curvas de DSC foram obtidas no equipamento da marca NETZSCH, modelo STA 449 F3 Júpiter, disponível no DEMAR.

Os filmes poliméricos foram preparados com e sem celulose, empregando de 10 a $15 \mathrm{mg}$ de material utilizando o método descrito na Tabela 2 e Figura 5. As análises foram realizadas com hélio como gás de purga sob fluxo de $100 \mathrm{~mL} / \mathrm{min}$ e nitrogênio como gás protetivo do sistema de aquecimento ${ }^{(45,46)}$. 
Tabela 2 - Método utilizado no DSC.

\begin{tabular}{|c|c|}
\hline Parâmetros & Valores \\
\hline 1 Resfriamento & -150ㄷ com nitrogênio líquido ligado (dados não adquiridos) \\
\hline \multirow[t]{3}{*}{ 10 Aquecimento } & $20^{\circ} \mathrm{C} /$ minuto até $40^{\circ} \mathrm{C}$ com nitrogênio líquido ligado \\
\hline & $20^{\circ} \mathrm{C} /$ minuto até $300^{\circ} \mathrm{C}$ com nitrogênio líquido desligado \\
\hline & Isoterma de 10 minutos com nitrogênio líquido ligado \\
\hline \multirow[t]{2}{*}{$2^{\circ}$ Resfriamento } & $-150^{\circ} \mathrm{C}$ com nitrogênio líquido ligado \\
\hline & Isoterma de 5 minutos com nitrogênio líquido ligado \\
\hline \multirow[t]{3}{*}{ 2ㅇ Aquecimento } & $20^{\circ} \mathrm{C} /$ minuto até $40^{\circ} \mathrm{C}$ com nitrogênio líquido ligado \\
\hline & $20^{\circ} \mathrm{C} /$ minuto até $300^{\circ} \mathrm{C}$ com nitrogênio líquido desligado \\
\hline & $20^{\circ} \mathrm{C} /$ minuto até $350^{\circ} \mathrm{C}$ com nitrogênio líquido desligado \\
\hline
\end{tabular}

Fonte: própria do autor.

Figura 5 - Método utilizado para as análises do DSC.

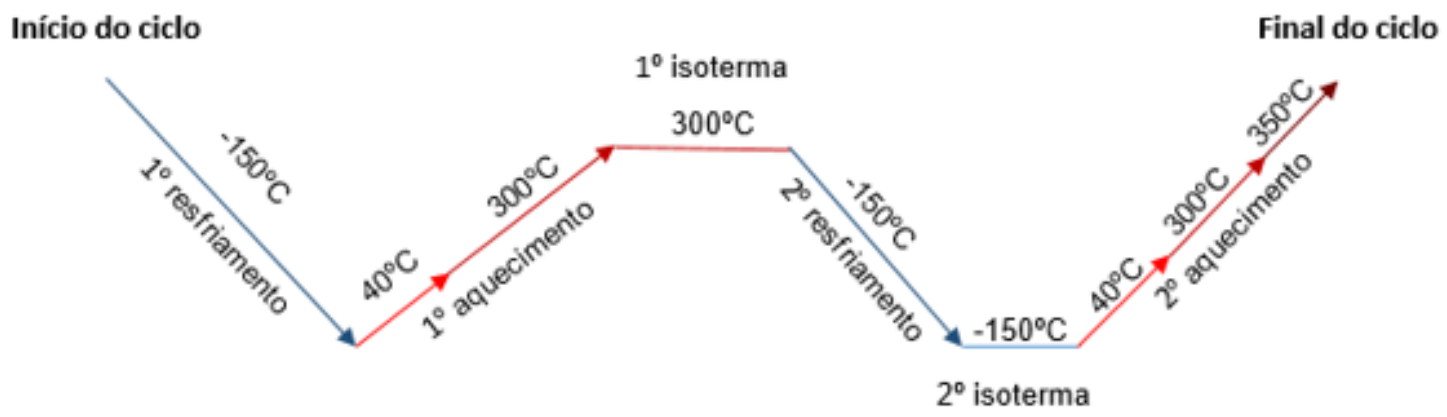

Fonte: Própria do autor. 


\section{- Análise Termogravimétrica (TGA)}

As análises de TGA foram realizadas para verificar o comportamento de decomposição térmica dos materiais. As curvas foram obtidas no equipamento da marca NETZSCH, modelo STA 449 F3 Júpiter, disponível no DEMAR.

Os filmes poliméricos foram preparados com e sem celulose, empregando de 12 a $13 \mathrm{mg}$ de resíduo. As análises foram realizadas com nitrogênio como gás de purga $(100 \mathrm{~mL} / \mathrm{min})$ e como gás protetivo do sistema de aquecimento sob uma taxa de aquecimento de $10^{\circ} \mathrm{C} / \mathrm{min}$, partindo da temperatura ambiente até $900{ }^{\circ} \mathrm{C}(45,46)$.

\subsubsection{Etapa 2: Processamento dos resíduos e separação da celulose}

- Separação via técnica de hidro-polpação: foram realizados ensaios para separação da celulose presente na composição do material por meio da técnica de hidro-polpação. A separação da celulose do material polimérico foi realizada com auxílio de um misturador rotativo disponível no DEMAR, em que os resíduos são misturados em água sem a presença de aditivos químicos e depois permaneceram sob agitação constante para hidratar as fibras de celulose e promover a separação da celulose dos filmes poliméricos. Esse procedimento foi realizado em dois ciclos, repetindo o mesmo procedimento. Para o segundo ciclo foi utilizada água recuperada do primeiro ciclo. A separação da celulose foi realizada com o auxílio de uma peneira com malha de 20 mesh. Para cada ciclo o material permaneceu sob agitação durante 40 minutos.

- Lavagem e Secagem: após o procedimento de separação foi necessário lavar o resíduo polimérico que permaneceu insolúvel após a hidro-polpação para remover a celulose residual. Esse procedimento foi realizado em um equipamento da marca MAGIDO modelo L55 CT, disponível no DEMAR, empregando um tempo de lavagem de 60 minutos. Na sequência este material foi seco em uma estufa QUIMIS, modelo BG 4000, disponível no DEMAR, à $80{ }^{\circ} \mathrm{C}$ por 24 horas. Testes preliminares foram conduzidos para determinar a temperatura máxima de secagem sem que houvesse a plastificação do material polimérico. 
O material polimérico resultante da separação da celulose lavado e seco foi submetido ao processamento por:

- Moagem: realizada em um moinho de facas da marca MQ MESSO, disponível no DEMAR, sob temperatura ambiente por 20 minutos. A moagem foi realizada para que o material fosse convertido em partículas de filmes com tamanho reduzido para 0 processamento termomecânico por extrusão.

- Aquecimento após moagem: os resíduos foram aquecidos novamente à $80 \stackrel{\circ}{C}$ por 50 minutos para promover a aglutinação das partículas de filmes. Este procedimento leva à mudança de forma das partículas inicialmente como filmes para estruturas em formato de flocos, facilitando a alimentação do material na extrusora em etapa subsequente de processamento.

- Extrusão: foi realizada a extrusão de cada resíduo separadamente, a fim de proporcionar a mistura termomecânica dos componentes poliméricos em estado fundido e conduzir o material ao formato de grânulos (pellets), caracterizando-o como um material reciclado. A extrusão foi realizada em uma extrusora mono-rosca piloto da marca IMACOM, disponível no DEMAR e a peletização (granulação) em um dispositivo acoplado à extrusora. $O$ perfil de temperatura utilizado no equipamento foi de $80 \stackrel{\circ}{ } \mathrm{C}, 170 \stackrel{\circ}{\circ} \mathrm{C}, 180{ }^{\circ} \mathrm{C}$ e $190{ }^{\circ} \mathrm{C}$ a partir da zona de alimentação para a matriz e a rotação da rosca de extrusão foi ajustada para 60 rpm.

- Secagem: após a extrusão o material granulado foi submetido à secagem novamente na estufa QUIMIS, por 16 horas e a $60{ }^{\circ} \mathrm{C}$.

- Moldagem por injeção: os materiais foram peletizados e submetidas à moldagem por injeção para produzir os corpos de prova destinados para caracterização de propriedades mecânicas, térmicas e reológicas dos materiais produzidos. Nesse processo foi utilizando uma injetora de termoplásticos da marca DIPLOMAT e modelo SPAZIO DW-130, disponível no DEMAR. As condições de operação da injetora estão apresentadas na Tabela 3. 
Tabela 3 - Condições de operação da injetora.

\begin{tabular}{ll}
\hline Parâmetros & Valores \\
\hline & \\
Temperatura zona 4 (alimentação) & $180^{\circ} \mathrm{C}$ \\
Temperatura zona 3 & $200^{\circ} \mathrm{C}$ \\
Temperatura zona 2 & $220^{\circ} \mathrm{C}$ \\
Temperatura zona 1 (bico) & $220^{\circ} \mathrm{C}$ \\
Pressão de injeção & $70 \mathrm{Bar}$ \\
Pressão de recalque & $90 \mathrm{Bar}$ \\
Velocidade de rosca & $30 \mathrm{RPM}$ \\
\end{tabular}

Fonte: Própria do autor.

\subsubsection{Etapa 3: Caracterizações dos materiais após processamento}

Na terceira etapa do estudo foram utilizadas as técnicas de espectroscopia no infravermelho por transformada de Fourier (FTIR), calorimetria exploratória diferencial (DSC), termogravimetria (TGA), microscopia eletrônica de varredura (MEV), análise dinâmico-mecânica (DMA), ensaios mecânicos de tração e impacto. Para as técnicas de FTIR, DSC, e TGA foram empregados os mesmos procedimentos de análise previamente descritos, enquanto as demais técnicas são assim descritas:

\section{- Microscopia Eletrônica de Varredura (MEV)}

As imagens da microscopia eletrônica foram utilizadas para caracterizar a morfologia superficial da seção transversal em detalhes. Para obter as imagens, os materiais foram submersos em nitrogênio líquido durante 30 minutos, e depois foram submetidos à fratura frágil na seção transversal. Depois da fratura os materiais foram fixados sobre uma placa de aço por meio da colagem de uma fita de carbono, que essa também é colocada na base até a superfície com o intuito de aterrar a superfície da fratura, e aplicada uma fina camada de ouro de aproximadamente $20 \mathrm{~nm}$ em uma metalizadora da marca MEDO 020, modelo BAL-TEC/MCS MULTICONTROL SYSTEM. As imagens foram obtidas em vários aumentos, com sinal de elétrons retro- 
espalhados em uma voltagem de $15 \mathrm{kv}$ utilizando o equipamento da marca HITACHI e modelo TM3000 e o equipamento da marca LEO e modelo 1450VP, disponíveis no DEMAR.

\section{- Análise dinâmico-mecânico (DMA)}

A análise de DMA foi utilizada com o propósito de estudar as relaxações térmicas e comportamento dinâmico-mecânico dos materiais após a injeção. Para os ensaios foram utilizados corpos de prova injetados na forma de barras com dimensões de 10,0 x 3,2 x 50.0 milímetros e as análises realizadas em um equipamento da marca NETZSCH e modelo DMA 242 E Artemis disponível no DEMAR, no modo Dual (Single) Cantilever Bending. As condições de ensaios estão descritas na Tabela 4:

Tabela 4 - Condições de operação do DMA.

\begin{tabular}{lc}
\hline Parâmetros & Valores \\
\hline Amplitude & $10 \mu \mathrm{m}$ \\
Frequência & $1 \mathrm{~Hz}$ \\
Força estática & $4 \mathrm{kN}$ \\
Força dinâmica & $4 \mathrm{kN}$ \\
Faixa de temperatura & -150 até $220^{\circ} \mathrm{C}$ \\
Taxa de resfriamento & $2 \stackrel{\circ}{\mathrm{C}} /$ minuto \\
Taxa de aquecimento & $2{ }^{\circ} \mathrm{C} /$ minuto \\
\hline
\end{tabular}

Fonte: Própria do autor.

\section{- Ensaio de Tração}

O ensaio de tração foi realizado de acordo com a norma ASTM D638, de 2013. Foram utilizados 8 a 10 corpos de prova para cada material, no equipamento da marca SHIMADZU e modelo AG-X, pertencente ao Departamento de Engenharia de Materiais e Tecnologia da Universidade Estadual Paulista (UNESP), com célula de carga de $5 \mathrm{kN}$ em uma velocidade de $50 \mathrm{~mm} / \mathrm{min}$. Neste ensaio, foram avaliadas as propriedades de resistência à tração, módulo de Young, tenacidade, porcentagem de 
alongamento e limite de escoamento. Na Figura 6 é apresentada a ilustração do corpo de prova de tração com as informações das dimensões e o formato.

Figura 6 - Dimensões do corpo de prova para o ensaio de tração.

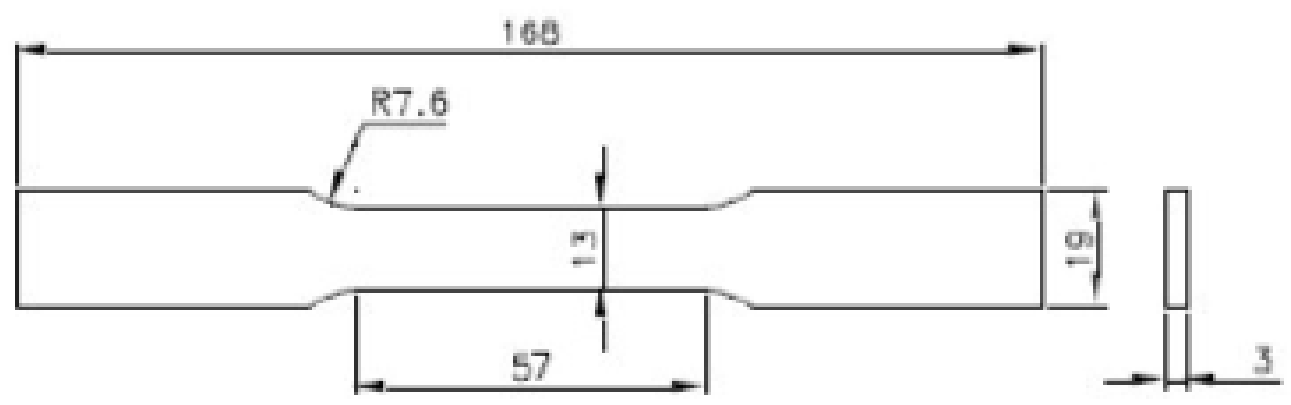

Fonte: (47).

\section{- Ensaio de Impacto}

O ensaio de impacto foi conduzido conforme a norma ASTM D256, de 2002 e método Izod em um equipamento da marca XJU-22 Beam Impact Tester, disponível no DEMAR. Foram utilizados 8 a 10 corpos de prova para cada material, com entalhe confeccionado no DEMAR, de acordo com a ASTM D256 e para a realização do ensaio foi utilizado um martelo de 2,7 joules. Na Figura 7 é apresentada a ilustração do corpo de prova de impacto com as informações das dimensões e entalhe.

Figura 7 - Dimensões do corpo de prova para o ensaio de impacto.

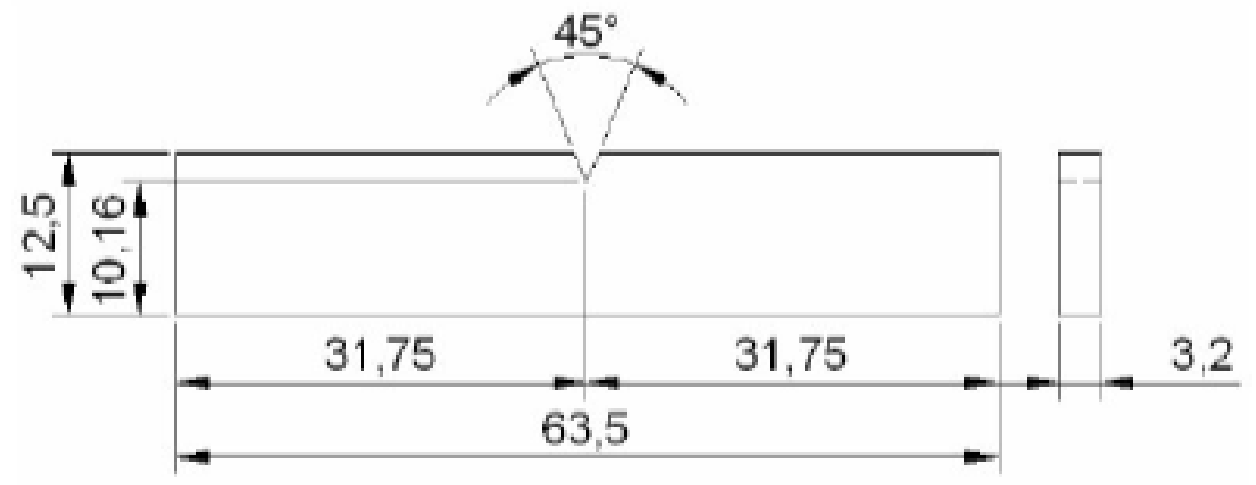

Fonte: (48). 


\subsubsection{Etapa 4: Reciclagem dos materiais na forma de blendas poliméricas}

Esta etapa teve como intuito avaliar o potencial da reciclagem dos resíduos poliméricos após a remoção da celulose na forma de blendas com resíduos de polietileno de baixa densidade pós-industrial (PEBD reciclado). Esta operação consistiu em misturar os resíduos processados dos resíduos CABE, CABC, CABR e CAT nas porcentagens de 10\%, 15\% e 20\% junto com o PEBD reciclado, com excessão do resíduo CABE que foi conduzido apenas nas proporções de 10 e 15\%, de modo que pudesse atingir uma condição de processabilidade do material. As misturas homogeneizadas foram extrudadas e corpos de provas de tração e de impacto foram obtidos por meio de moldagem por injeção dos materiais.

- Extrusão: foi realizada a extrusão de cada resíduo com o PEBD reciclado separadamente, para proporcionar a mistura termomecânica dos componentes poliméricos em estado fundido e conduzir o material ao formato de grânulos (pellets), utilizando as mesmas condições de processamento descritas na etapa 3.

- Secagem: após a extrusão o material granulado foi submetido à secagem novamente na estufa QUIMIS, modelo BG 4000, por 12 horas e a $70{ }^{\circ} \mathrm{C}$.

- Moldagem por injeção: os materiais foram peletizados e submetidos à moldagem por injeção para produzir os corpos de prova destinados para caracterização de propriedades mecânicas. Neste processo foram utilizadas as mesmas condições de processamento descritas na etapa 3.

Os corpos de prova obtidos após à moldagem por injeção foram submetidos aos ensaios mecânicos de tração e impacto para avaliar seus potenciais para serem utilizados como blendas.

- Ensaio de tração: O ensaio de tração foi realizado de acordo com a norma ASTM D638, de 2013. Foram utilizados 10 corpos de prova para cada material, no equipamento da marca EMIC DL 3000, disponível no DEMAR, com célula de carga de $5 \mathrm{kN}$ em uma velocidade de $50 \mathrm{~mm} / \mathrm{min}$. Neste ensaio, foram avaliadas as 
propriedades de resistência à tração, módulo de Young, tenacidade, porcentagem de alongamento e limite de escoamento.

- Ensaio de impacto: Para o ensaio de impacto foi realizado conforme já previamente descrito na etapa 3. 


\section{RESULTADOS E DISCUSSÃo}

\subsection{Caracterização dos Materiais (etapa 1):}

Nas Figuras 8 a 11 são apresentadas as imagens obtidas por microscopia ótica (MO) dos quatro resíduos distintos de adesivos curativos.

Figura 8 - Imagem do filme multicamada do resíduo CABE.

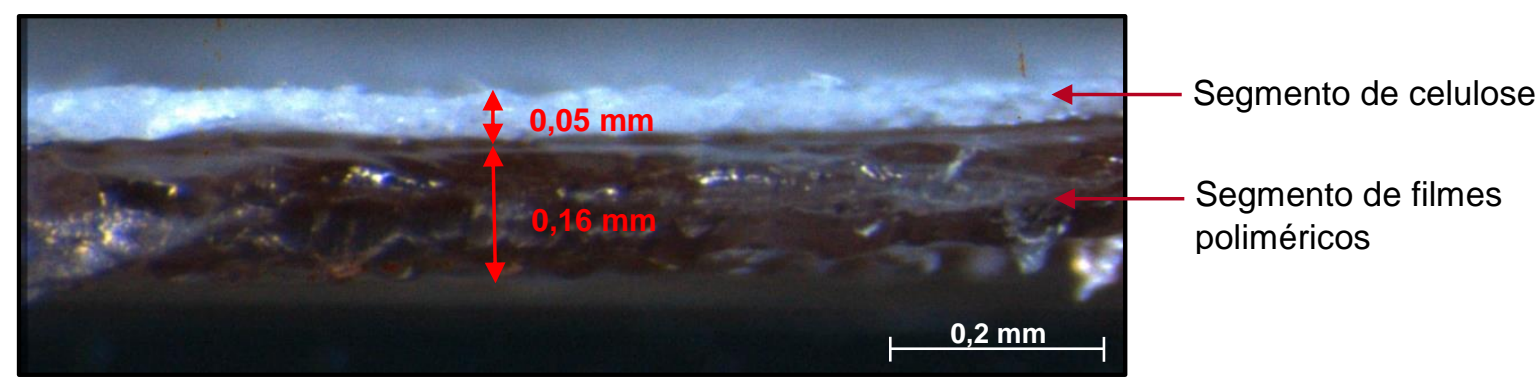

Fonte: Própria do autor.

Figura 9 - Imagem do filme multicamada do resíduo CABC.

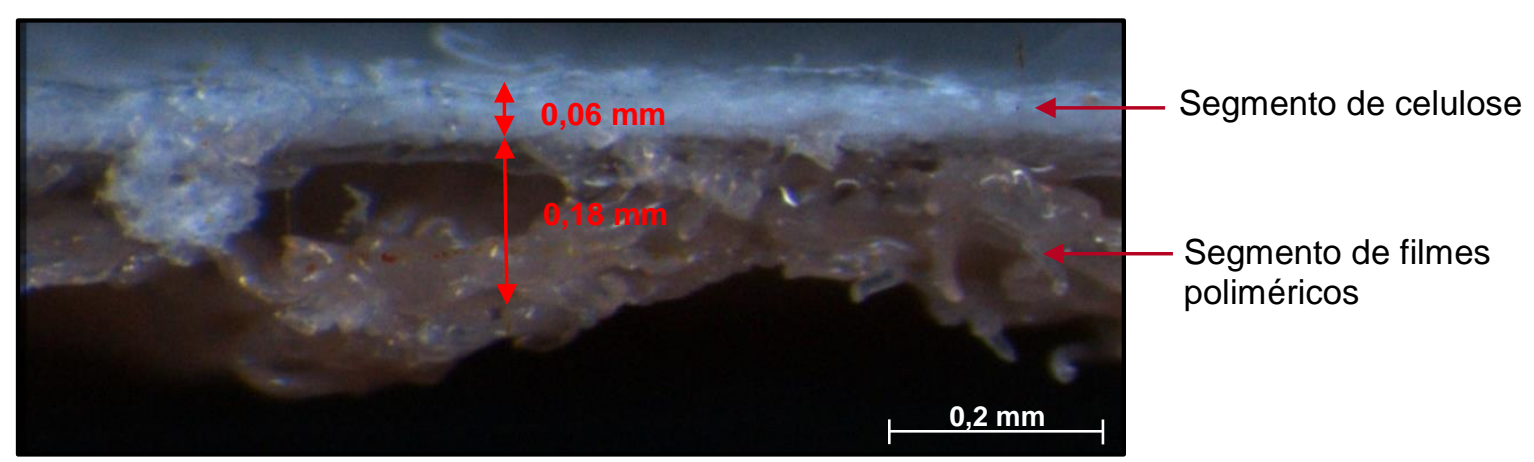

Fonte: Própria do autor. 
Figura 10 - Imagem do filme multicamada do resíduo CABR.

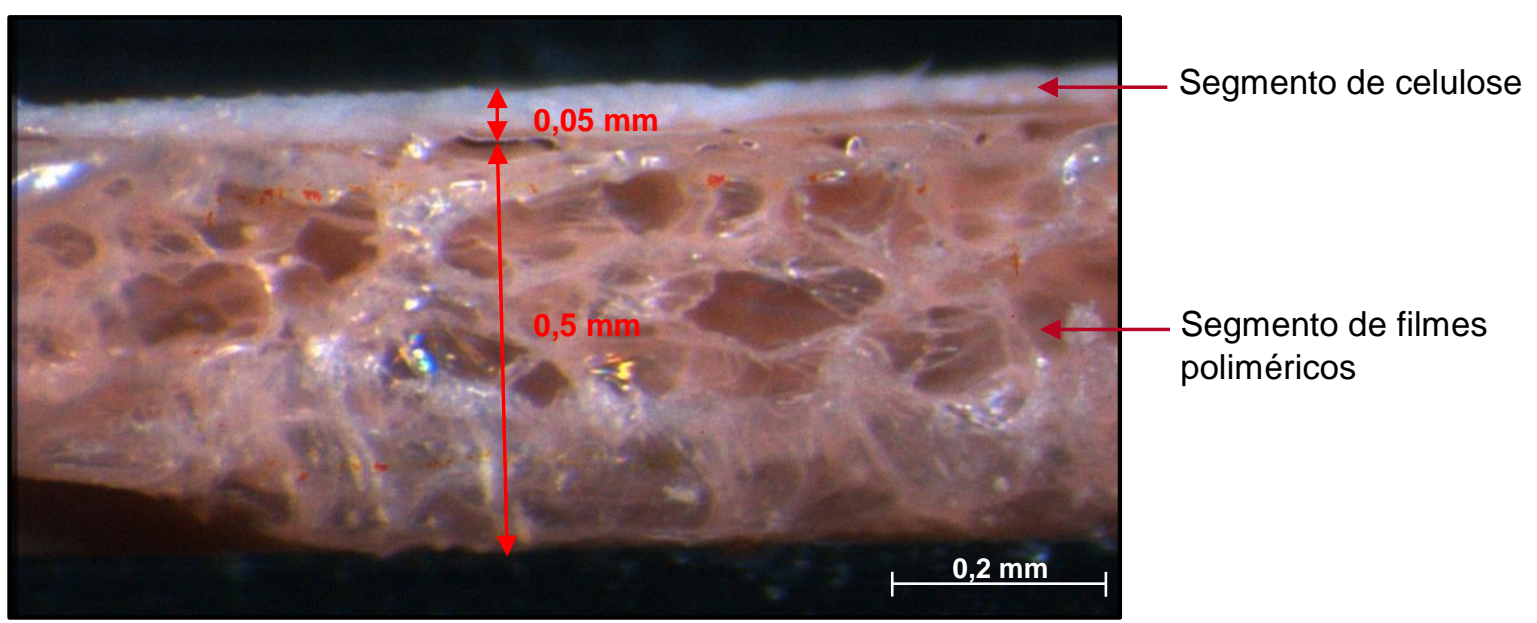

Fonte: Própria do autor.

Figura 11 - Imagem do filme multicamada do resíduo CAT.

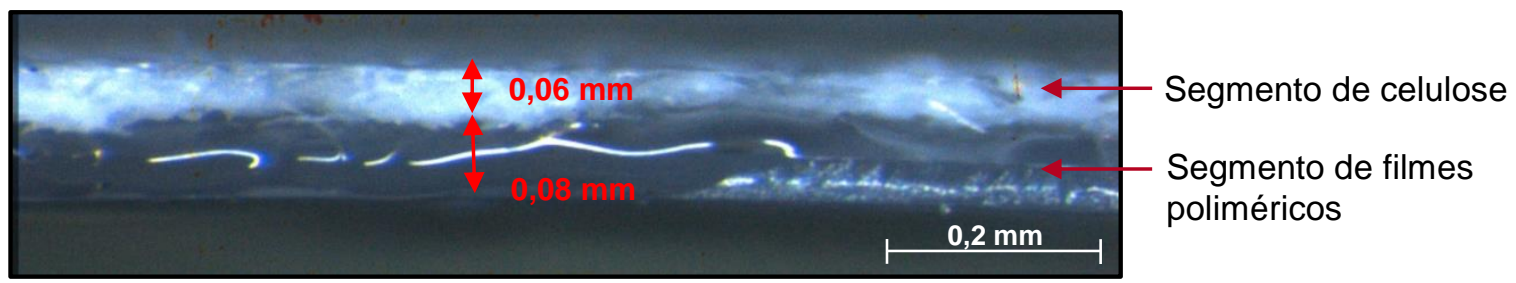

Fonte: Própria do autor.

É possível observar em todos os resíduos uma camada branca na parte superior das imagens que são correspondentes à celulose. Para essa camada, os resíduos CABE e CABR apresentaram espessura de $0,05 \mathrm{~mm}$, enquanto para os resíduos CABC e CAT a espessura foi de 0,06 $\mathrm{mm}$.

Logo abaixo da camada da celulose é observada uma estrutura correspondente a camada de filmes poliméricos. Nessa camada, a espessura para o resíduo CABE é de $0,16 \mathrm{~mm}$, para o resíduo CABC é de $0,18 \mathrm{~mm}$, no resíduo CABR é 0,5 $\mathrm{mm}$ e para o resíduo CAT é de $0,08 \mathrm{~mm}$. Estas camadas também podem ser observadas a olho nu.

$\mathrm{Na}$ prática, quando foi realizada uma simples análise visual destes materiais, notou-se que a camada de filmes poliméricos se desprende facilmente da camada da celulose; ação esperada em função da própria engenharia de curativos adesivos sensíveis à pressão, que são feitos para que a camada de filmes poliméricos seja facilmente removida e aplicada na pele. 
No entanto, a estrutura física da porção polimérica dos filmes é mais complexa e diferente para cada resíduo. Basicamente esta é composta de duas camadas de filmes, sendo um revestimento superior e uma camada de adesivo que se adere à pele após a sua aplicação. Foi notado também, para todos os resíduos, que os dois filmes são laminados juntos e não se separam, ficando aderidos um ao outro.

Por outro lado, a camada branca do filme não é composta somente por celulose, mas também por um filme fino de material polimérico transparente e brilhante, laminado junto à celulose, que faz parte da engenharia de curativos adesivos sensíveis à pressão como facilitador do processo de separação das camadas em questão e para não comprometer a função do filme adesivo para aplicação na pele. Foi notado que esta camada de filme transparente não se desprende da camada de celulose, para os resíduos CABE e CABR, ao contrário do que é observado nos resíduos $\mathrm{CABC}$ e CAT, em que este facilmente pode ser removido.

Com base nas avaliações, pode-se afirmar que os resíduos de curativos na forma de filmes são constituídos por quatro camadas distintas de materiais, as quais são representadas na Figura 12. É importante ressaltar que, dependendo do tipo de processamento de laminação das camadas para a fabricação do filme multicamada, pode haver modificações químicas ou junção de camadas adjacentes dos materiais constituintes. Logo, a existência de mais camadas ou alteração da composição de cada camada podem ocorrer.

Figura 12 - llustração da composição do resíduo de curativo.

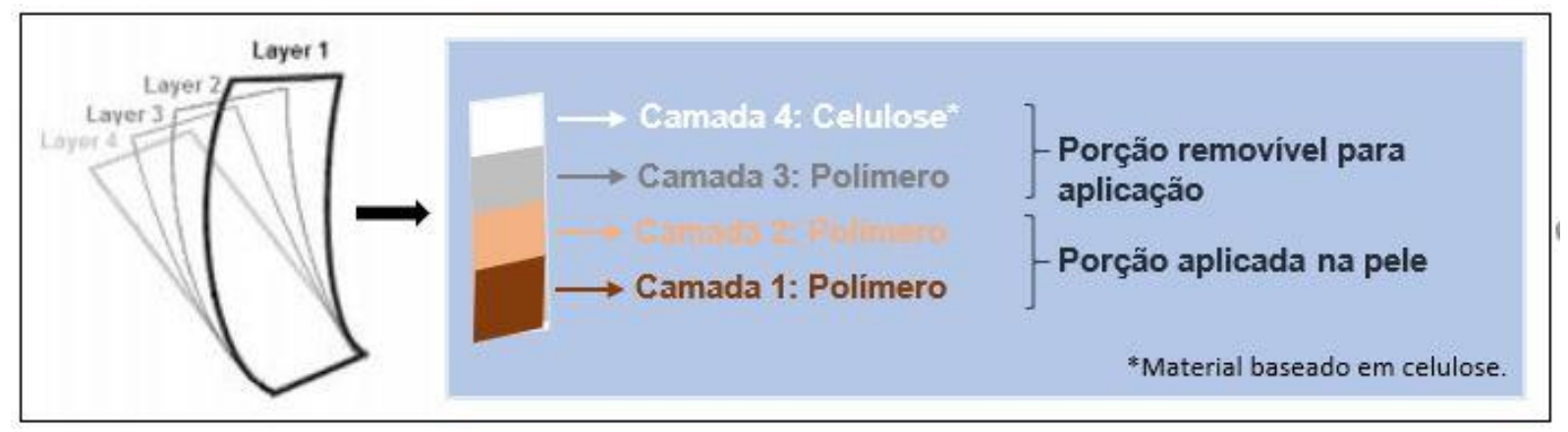

Fonte: Própria do autor. 
Mediante as análises realizadas e informações prestadas pelo fabricante, é possível descrever a estrutura física e função das camadas dos filmes. Assim, a camada 1 trata-se de um polímero com função estrutural do curativo, enquanto a camada 2 é um adesivo com função de aderir-se à pele durante a aplicação; a camada 3 é um polímero de revestimento da celulose com função de facilitador do processo da porção removível do material, além de proteger a camada 2 e a camada 4 é constituída por um material baseado em celulose, podendo ser alterada conforme 0 modo de manufatura ou composição. Essa camada 4 tem a função de facilitar a aplicação do curativo adesivo sensível à pressão na pele.

No sentido de identificar os polímeros constituintes de cada camada e respectiva estabilidade térmica, os materiais foram analisados por meio das técnicas de FTIR, DSC e TGA. Vale ressaltar que devido a impossibilidade de separação física, as camadas 1 e 2 de todos os resíduos foram analisadas juntos. O mesmo ocorreu para as camadas 3 e 4 . Somente nos resíduos CABC e CAT a camada 3 foi analisada separadamente da camada 4 .

\section{- Espectroscopia no Infravermelho por Transformada de Fourier (FTIR)}

As Figuras 13 a 15 apresentam os espectros de FTIR das camadas de cada resíduo, obtidos no modo ATR. Na Figura 16 são apresentados espectros de resíduos do polietileno de baixa densidade (PEBD), polipropileno (PP) e copolímeros de etilenoacetato de vinila (EVA) e celulose para comparação com as camadas 1 e 2 analisadas juntas, 3 e 4 analisadas juntas e camada 3 isolada. Esta comparação foi feita em função de que os polímeros citados são materiais muito empregados para este tipo de aplicação e possíveis constituintes dos resíduos em estudo, logo estes materiais foram definidos como referências padrão. 
Figura 13 - Espectros de FTIR das camadas 1 e 2 para os resíduos CABE, CABC, CABR e CAT.

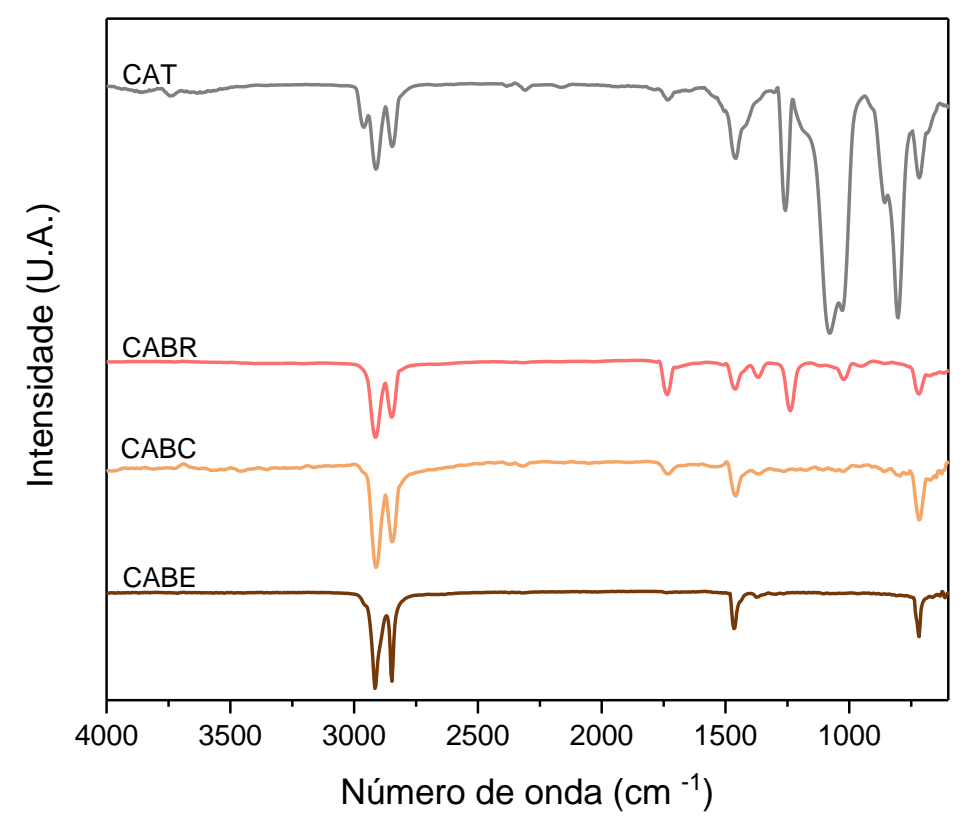

Fonte: Própria do autor.

Figura 14 - Espectros de FTIR das camadas 3 e 4 para os resíduos CABE, CABC, CABR e CAT.

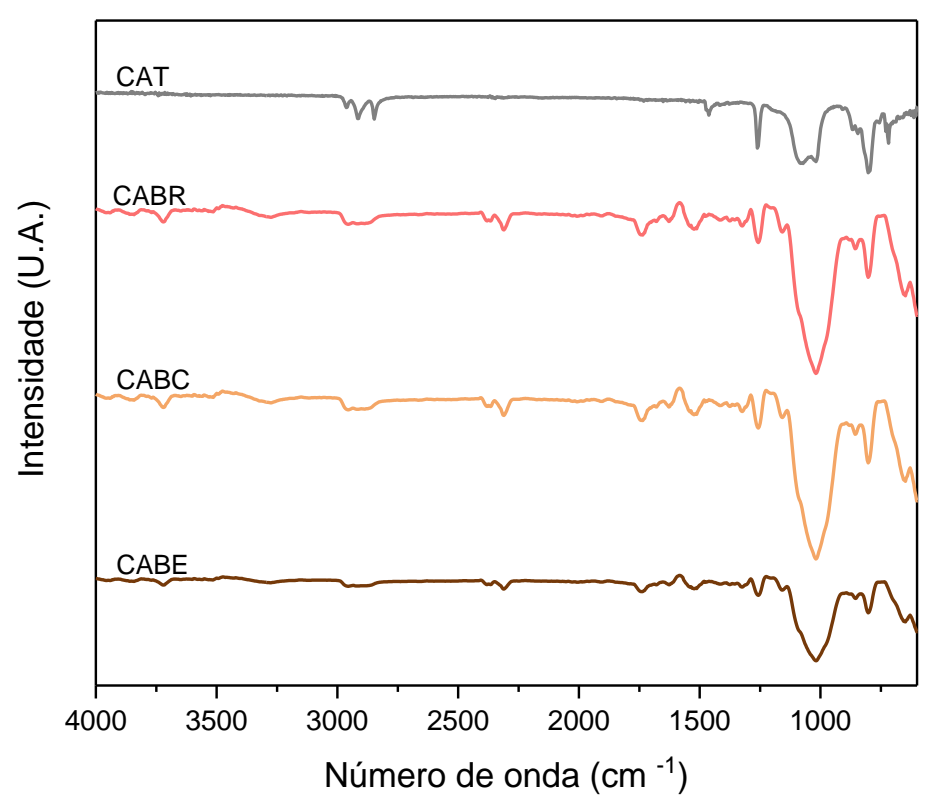

Fonte: Própria do autor. 
Figura 15 - Espectros de FTIR da camada 3 para os resíduos CABC e CAT.

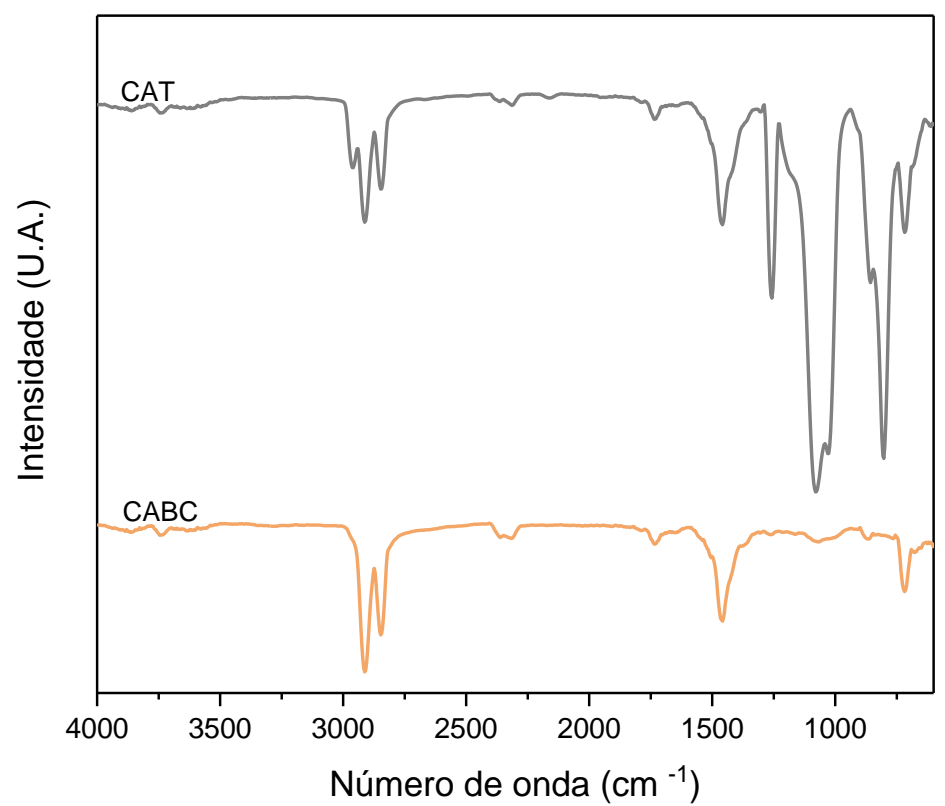

Fonte: Própria do autor.

Figura 16 - Espectros de FTIR das referências padrão Celulose, PEBD, PP e EVA.

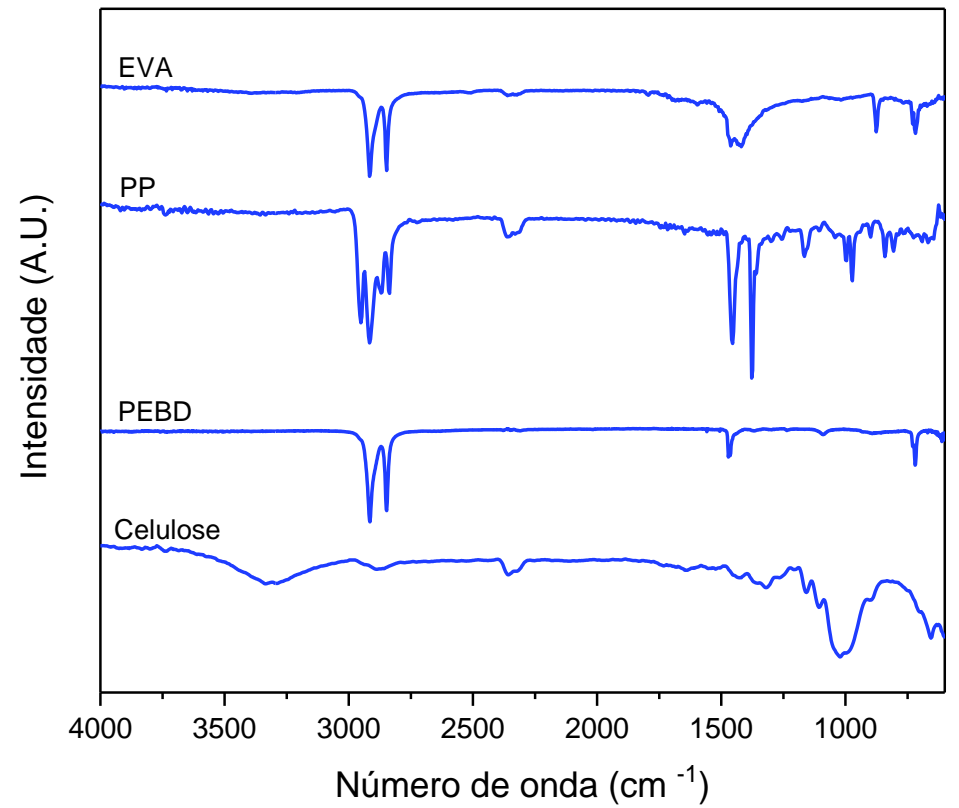

Fonte: Própria do autor. 
A Tabela 5 apresenta a atribuição das bandas de FTIR dos espectros das Figuras 13 a 15.

Tabela 5 - Bandas de FTIR dos resíduos em suas respectivas camadas.

\begin{tabular}{|c|c|c|c|c|}
\hline Material & Camadas & $\begin{array}{l}\text { Número de Onda } \\
\left(\mathrm{cm}^{-1}\right)\end{array}$ & $\begin{array}{l}\text { Grupo } \\
\text { Funcional }\end{array}$ & Modo Vibracional \\
\hline \multirow[t]{3}{*}{ CABE } & 1 e 2 & $3000-2800$ & $\mathrm{C}-\mathrm{H}$ & $\begin{array}{l}\text { Deformações axiais simétrica } \mathrm{e} \\
\text { assimétrica de } \mathrm{CH}_{2} \text {. }\end{array}$ \\
\hline & & $1500-1400$ & $\mathrm{C}-\mathrm{H}$ & $\begin{array}{l}\text { Deformação angular simétrica e } \\
\text { assimétrica de } \mathrm{CH}_{2} \text { e } \mathrm{CH}_{3} \text {. }\end{array}$ \\
\hline & & Próximo à 720 & $\mathrm{C}-\mathrm{H}$ & $\begin{array}{l}\text { Deformação angular assimétrica } \\
\text { de } \mathrm{CH}_{2} \text {. }\end{array}$ \\
\hline CABE & 3 e 4 & Próximo à 1000 & $\mathrm{C}-\mathrm{H}$ & $\begin{array}{l}\text { Deformação angular simétrica de } \\
\mathrm{CH} \text { fora do plano. }\end{array}$ \\
\hline \multirow[t]{4}{*}{$\mathrm{CABC}$} & 1 e 2 & $3000-2800$ & $\mathrm{C}-\mathrm{H}$ & $\begin{array}{l}\text { Deformações axiais simétrica e } \\
\text { assimétrica de } \mathrm{CH}_{2} \text {. }\end{array}$ \\
\hline & & $1750-1735$ & $\mathrm{C}=\mathrm{O}$ & Deformação de $\mathrm{C}=\mathrm{O}$ de éster. \\
\hline & & $1500-1400$ & $\mathrm{C}-\mathrm{H}$ & $\begin{array}{l}\text { Deformação angular simétrica e } \\
\text { assimétrica de } \mathrm{CH}_{2} \text { e } \mathrm{CH}_{3} \text {. }\end{array}$ \\
\hline & & Próximo à 720 & $\mathrm{C}-\mathrm{H}$ & $\begin{array}{l}\text { Deformação angular assimétrica } \\
\text { de } \mathrm{CH}_{2} \text {. }\end{array}$ \\
\hline CABC & 3 e 4 & Próximo à 1000 & $\mathrm{C}-\mathrm{H}$ & $\begin{array}{l}\text { Deformações angular simétrica } \\
\text { de } \mathrm{CH} \text { fora do plano. }\end{array}$ \\
\hline \multirow[t]{3}{*}{ CABC } & 3 & $3000-2800$ & $\mathrm{C}-\mathrm{H}$ & $\begin{array}{l}\text { Deformações axiais simétrica e } \\
\text { assimétrica de } \mathrm{CH}_{2} \text {. }\end{array}$ \\
\hline & & $1500-1400$ & $\mathrm{C}-\mathrm{H}$ & $\begin{array}{l}\text { Deformação angular simétrica e } \\
\text { assimétrica de } \mathrm{CH}_{2} \text { e } \mathrm{CH}_{3} \text {. }\end{array}$ \\
\hline & & Próximo à 720 & $\mathrm{C}-\mathrm{H}$ & $\begin{array}{l}\text { Deformação angular assimétrica } \\
\text { de } \mathrm{CH}_{2} \text {. }\end{array}$ \\
\hline \multirow[t]{4}{*}{ CABR } & 1 e 2 & $3000-2800$ & $\mathrm{C}-\mathrm{H}$ & $\begin{array}{l}\text { Deformações axiais simétrica e } \\
\text { assimétrica de } \mathrm{CH}_{2} \text {. }\end{array}$ \\
\hline & & $1750-1735$ & $\mathrm{C}=\mathrm{O}$ & Deformação de $\mathrm{C}=\mathrm{O}$ de éster. \\
\hline & & $1500-1400$ & $\mathrm{C}-\mathrm{H}$ & $\begin{array}{l}\text { Deformação angular simétrica e } \\
\text { assimétrica de } \mathrm{CH}_{2} \text { e } \mathrm{CH}_{3} \text {. }\end{array}$ \\
\hline & & $1200-1000$ & $\mathrm{C}-\mathrm{O}$ & $\begin{array}{l}\text { Deformação de C-O em duas ou } \\
\text { mais bandas. }\end{array}$ \\
\hline
\end{tabular}


Continuacão

\begin{tabular}{|c|c|c|c|c|}
\hline CABR & 1 e 2 & Próximo à 720 & $\mathrm{C}-\mathrm{H}$ & $\begin{array}{l}\text { Deformação angular assimétrica } \\
\text { de } \mathrm{CH}_{2} \text {. }\end{array}$ \\
\hline CABR & 3 e 4 & Próximo à 1000 & $\mathrm{C}-\mathrm{H}$ & $\begin{array}{l}\text { Deformações angular simétrica } \\
\text { de } \mathrm{CH} \text { fora do plano. }\end{array}$ \\
\hline \multirow[t]{5}{*}{ CAT } & 1 e 2 & $3000-2800$ & $\mathrm{C}-\mathrm{H}$ & $\begin{array}{l}\text { Deformações axiais simétrica e } \\
\text { assimétrica de } \mathrm{CH}_{2} \text {. }\end{array}$ \\
\hline & & $1750-1735$ & $\mathrm{C}=\mathrm{O}$ & Deformação de $\mathrm{C}=\mathrm{O}$ de éster. \\
\hline & & $1500-1400$ & $\mathrm{C}-\mathrm{H}$ & $\begin{array}{l}\text { Deformação angular simétrica e } \\
\text { assimétrica de } \mathrm{CH}_{2} \text { e } \mathrm{CH}_{3} \text {. }\end{array}$ \\
\hline & & $1200-800$ & $\mathrm{C}-\mathrm{C}$ & $\begin{array}{l}\text { Deformação angular assimétrica } \\
\text { no plano. }\end{array}$ \\
\hline & & Próximo à 720 & $\mathrm{C}-\mathrm{H}$ & $\begin{array}{l}\text { Deformação angular assimétrica } \\
\text { de } \mathrm{CH}_{2} \text {. }\end{array}$ \\
\hline \multirow[t]{6}{*}{ CAT } & 3 e 4 & $3000-2800$ & $\mathrm{C}-\mathrm{H}$ & $\begin{array}{l}\text { Deformações axiais simétrica e } \\
\text { assimétrica de } \mathrm{CH}_{2} \text {. }\end{array}$ \\
\hline & & $1500-1400$ & $\mathrm{C}-\mathrm{H}$ & $\begin{array}{l}\text { Deformação angular simétrica e } \\
\text { assimétrica de } \mathrm{CH}_{2} \text { e } \mathrm{CH}_{3} \text {. }\end{array}$ \\
\hline & & Próximo à 1200 & $\mathrm{C}-\mathrm{C}$ & $\begin{array}{l}\text { Deformação angular assimétrica } \\
\text { no plano. }\end{array}$ \\
\hline & & Próximo à 1000 & $\mathrm{C}-\mathrm{H}$ & $\begin{array}{l}\text { Deformações angular simétrica } \\
\text { de } \mathrm{CH} \text { fora do plano. }\end{array}$ \\
\hline & & Próximo à 800 & $\mathrm{C}-\mathrm{C}$ & $\begin{array}{l}\text { Deformação angular assimétrica } \\
\text { no plano. }\end{array}$ \\
\hline & & Próximo à 720 & $\mathrm{C}-\mathrm{H}$ & $\begin{array}{l}\text { Deformação angular assimétrica } \\
\text { de } \mathrm{CH}_{2} \text {. }\end{array}$ \\
\hline \multirow[t]{4}{*}{ CAT } & 3 & $3000-2800$ & $\mathrm{C}-\mathrm{H}$ & $\begin{array}{l}\text { Deformações axiais simétrica e } \\
\text { assimétrica de } \mathrm{CH}_{2} \text {. }\end{array}$ \\
\hline & & $1500-1400$ & $\mathrm{C}-\mathrm{H}$ & $\begin{array}{l}\text { Deformação angular simétrica e } \\
\text { assimétrica de } \mathrm{CH}_{2} \text { e } \mathrm{CH}_{3} \text {. }\end{array}$ \\
\hline & & $1200-800$ & $\mathrm{C}-\mathrm{C}$ & $\begin{array}{l}\text { Deformação angular assimétrica } \\
\text { no plano. }\end{array}$ \\
\hline & & Próximo à 720 & $\mathrm{C}-\mathrm{H}$ & $\begin{array}{l}\text { Deformação angular assimétrica } \\
\text { de } \mathrm{CH}_{2} \text {. }\end{array}$ \\
\hline
\end{tabular}

Fonte: Própria do autor.

A Figura 13 apresenta espectros de FTIR das camadas 1 e 2 para todos os resíduos. Observa-se que o resíduo CABE mostra o espectro mais simples com 
praticamente 4 bandas principais que também são verificadas nos resíduos CABR e CABC. O espectro do resíduo CABE apresenta muita semelhança com o espectro do PEBD ilustrado na Figura 16, considerando a intensidade e número de onda em que as bandas aparecem. Portanto, há uma indicação forte de que o material que constitui as camadas 1 e 2 do resíduo CABE seja o PEBD.

Os resíduos CABR e CABC apresentam um perfil de bandas muito parecido em seus espectros de FTIR, também com bandas características de PEBD, além de outras bandas que podem estar associadas a modos distintos de absorção da ligação $\mathrm{C}=\mathrm{O}$ e $\mathrm{C}-\mathrm{O}$ em baixa concentração no material. Estas bandas podem ser atribuídas a grupos acrílicos do material que se apresenta como um copolímero com o polietileno. Outra hipótese é devido ao tipo de processamento por laminação das camadas para a fabricação do filme, que pode ter gerado modificações químicas ou junção de camadas adjacentes dos materiais constituintes, resultando em uma possível alteração química.

O espectro do resíduo CAT é o que apresenta maior divergência com os demais materiais. Neste caso, as bandas em torno de $2900 \mathrm{~cm}^{-1}$ (Tabela 5) são características de estiramentos de ligação $\mathrm{C}-\mathrm{H}$ de compostos alifáticos com perfil que se aproxima ao do polipropileno (PP). Entretanto, as bandas em números de onda abaixo de 1500 $\mathrm{cm}^{-1}$ indicam a presença de ligações C-H e entre $1200-800 \mathrm{~cm}^{-1}$ indicam a presença de C-C, além de outra banda que pode estar associada a modo distinto de absorção da ligação $\mathrm{C}=\mathrm{O}$ em baixa concentração, podendo ser atribuída a grupos acrílicos do material. A possibilidade do material polimérico destas camadas ser formado por copolímeros também deve ser considerada.

A Figura 14 apresenta espectros de todos os resíduos para as camadas 3 e 4 analisadas juntas. Observa-se que os resíduos CABE, CABC e CABR apresentam bandas de FTIR nas mesmas regiões da referência padrão celulose, não podendo ser identificado com clareza outras vibrações em regiões das referências PEBD ou PP (Figura16). Quanto ao resíduo CAT (Figura 14), nota-se que são verificadas, além bandas características da celulose, também bandas características do filme que compõe as camadas 1 e 2.

A Figura 15 apresenta espectros de FTIR dos resíduos CABC e CAT para a camada 3 isolada. Para o resíduo CABC o espectro é semelhante ao das camadas 1 e 2 deste material, que por sua vez indica se tratar de um copolímero com o PEBD. Da mesma forma, o espectro da camada 3 do resíduo CAT é semelhante ao espectro 
das camadas 1 e 2 deste material. Assim, pode-se concluir que as camadas 1, 2 e 3 desse resíduo são confeccionados basicamente pelo mesmo tipo de polímero, levando em consideração que as camadas 1 e 2 foram analisadas juntas, podendo a camada 2 ter uma composição diferente da camada $1^{(49)}$.

\section{- Calorimetria Exploratória Diferencial (DSC)}

Nas Figuras 17 a 19 são apresentados os resultados de DSC referentes a etapa 1 do procedimento experimental. A Tabela 6 apresenta valores de temperatura em que foram verificados eventos térmicos a partir da análise das curvas de DSC.

Figura 17 - Curvas de DSC das camadas 1 e 2 para os resíduos CABE, CABC, CABR e CAT: a) primeiro aquecimento e b) segundo aquecimento.

a)

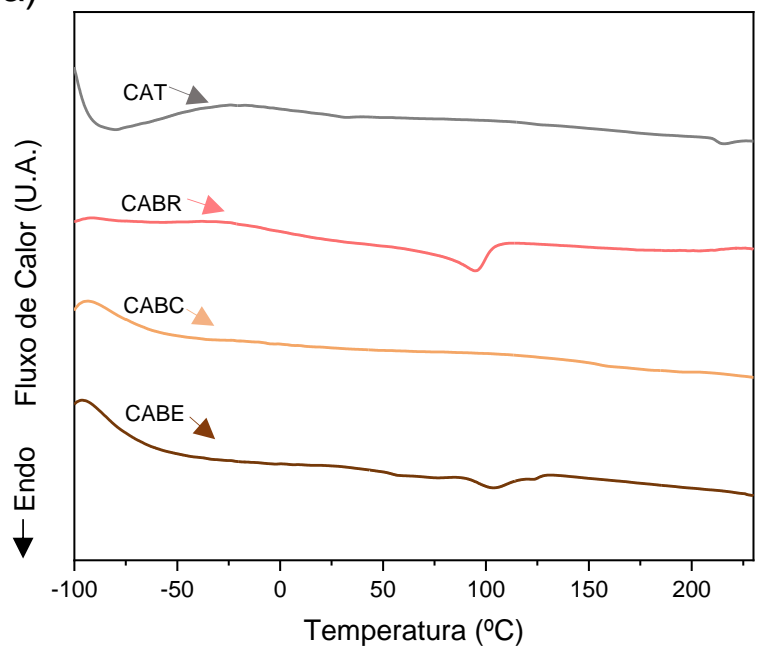

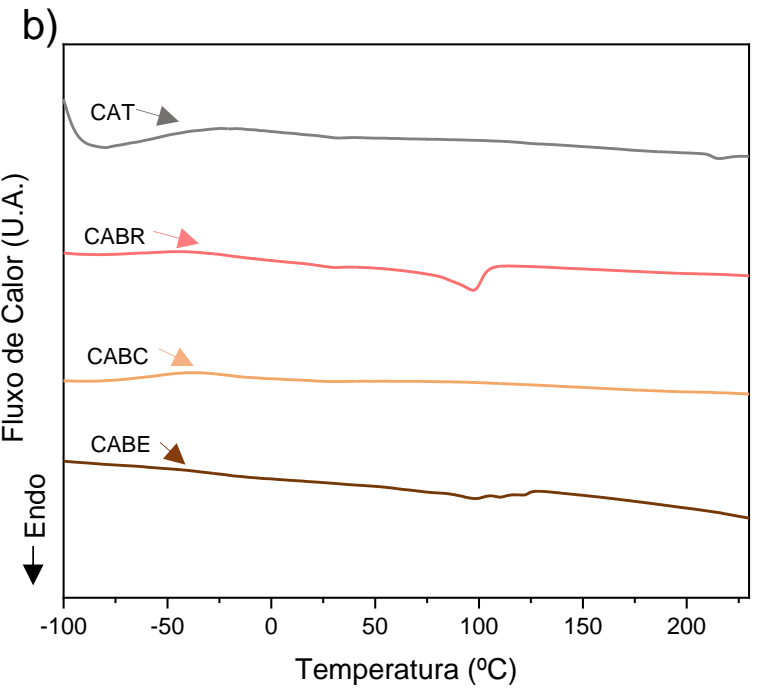

Fonte: Própria do autor.

Na curva de DSC de primeiro aquecimento do resíduo CABE (Figura 17a) notase um sinal endotérmico de baixa intensidade por volta de $100 \stackrel{\circ}{ } \mathrm{C}$. A partir deste ponto a curva mostra oscilações à linha base. Na curva de segundo aquecimento deste resíduo (Figura 17b) o sinal em torno de $100 \stackrel{\circ}{\mathrm{C}}$ novamente surge. Porém, o pico apresenta vários patamares até novamente retomar a linha base. O PEBD apresenta fusão na faixa de temperatura compatível com o sinal verificado reforçando as conclusões obtidas pela análise de FTIR ${ }^{(50)}$. Por outro lado, os patamares observados no sinal de fusão durante o segundo aquecimento denotam a existência de 
heterogeneidade de cristais no material, formados por cadeias de diferentes tamanhos ou com características distintas que apresentam pontos de fusão diferentes (51). Isto pode ser consequência de componentes do material que sofreram decomposição térmica ou que fundiram e não recristalizaram durante o resfriamento que precede o segundo aquecimento.

O resíduo CABR apresenta um comportamento muito parecido durante 0 primeiro aquecimento. Entretanto na curva de segundo aquecimento, o sinal endotérmico, o qual pode ser atribuído à fusão do PEBD, é bastante pronunciado e regular, reforçando as conclusões obtidas pela análise de FTIR.

O resíduo $C A B C$ somente apresenta uma inflexão em uma faixa larga de temperatura no intervalo aproximado de -50 a $0 \stackrel{\circ}{\circ}$, que pode ser atribuída a uma transição vítrea do material. Assim, o polímero encontra-se em grande proporção em estado amorfo, podendo ser um copolímero. Esse resultado reforça as conclusões obtidas pela análise de FTIR.

No resíduo CAT o perfil da curva de DSC é bastante parecido com o resíduo CABC, corroborando com as análises de FTIR. A curva de DSC de primeiro aquecimento apresenta uma inflexão em uma faixa larga de temperatura no intervalo aproximado de -50 a $0{ }^{\circ} \mathrm{C}$, enquanto o sinal de transição vítrea entre -50 a $0{ }^{\circ} \mathrm{C}$ é um pouco mais evidenciado, mostrando que este polímero é também amorfo. Esse resultado também é reforçado pelas conclusões obtidas pela análise de FTIR. 
A Figura 18 apresenta as curvas de DSC de primeiro e segundo aquecimento do material das camadas 3 e 4 dos resíduos.

Figura 18 - Curvas de DSC das camadas 3 e 4 para os resíduos CABE, CABC, CABR e CAT: a) primeiro aquecimento e b) segundo aquecimento.
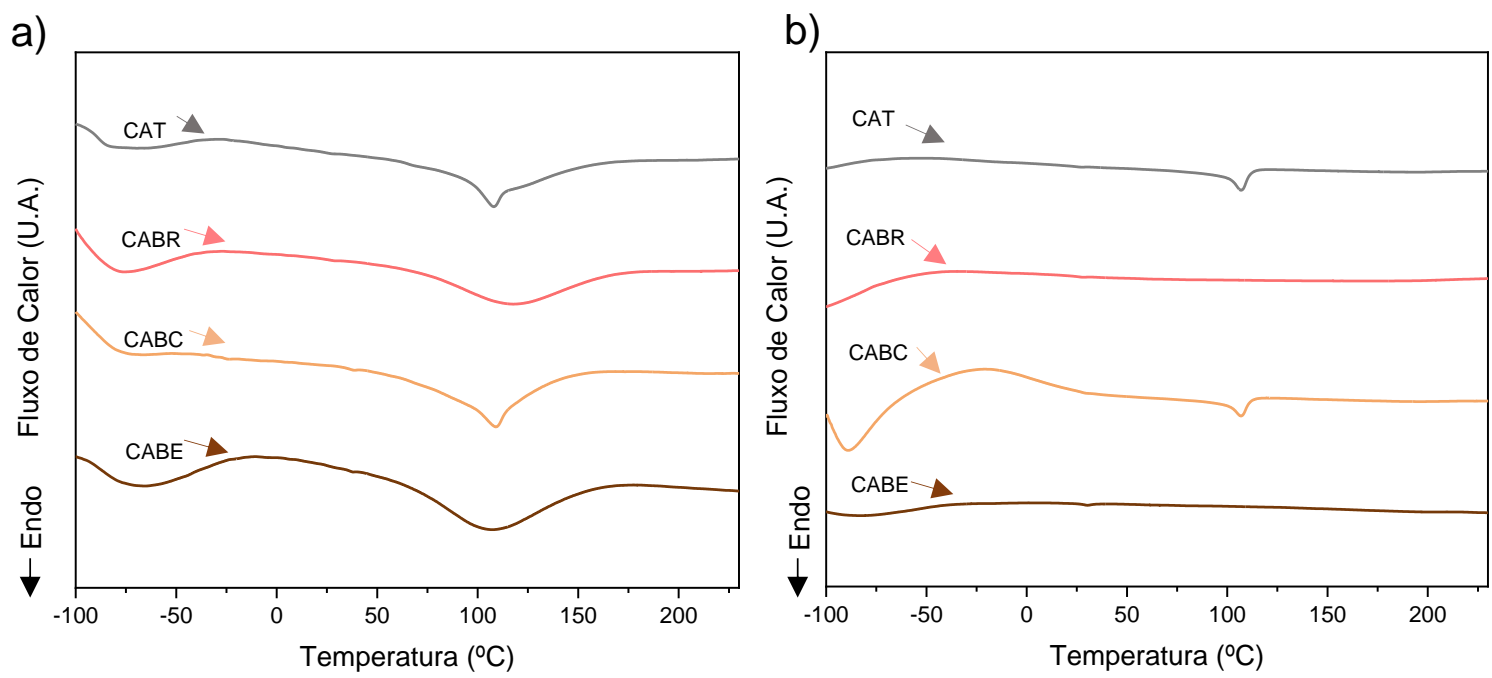

Fonte: Própria do autor.

O material das camadas 3 e 4 do resíduo CABE apresenta um comportamento parecido ao do material das 1 e 2 deste material. A diferença principal é a ausência do sinal em torno de $100^{\circ} \mathrm{C}$, atribuído à fusão do PEBD. Isto evidencia que o polímero destas camadas é amorfo.

O resíduo CABR também não apresenta o sinal endotérmico em torno de $100 \stackrel{\circ}{\mathrm{C}}$.

O sinal endotérmico em $100^{\circ} \mathrm{C}$, que pode ser atribuído à fusão do PEBD, é verificado nas curvas de DSC de primeiro e segundo aquecimento dos resíduos CABC e CAT. Este resultado reforça as conclusões obtidas pela análise de FTIR para o material CAT ${ }^{(49)}$. 
A Figura 19 apresenta a comparação de curvas de DSC do filme que compõe a camada 3 dos resíduos CABC e CAT.

Figura 19 - Curvas de DSC das camadas 3 e 4 dos resíduos CABC e CAT: a) curvas do primeiro aquecimento camada 3, b) curvas do segundo aquecimento camada 3, c) curvas do primeiro aquecimento camada 4 e d) curvas do segundo aquecimento camada 4.

a)

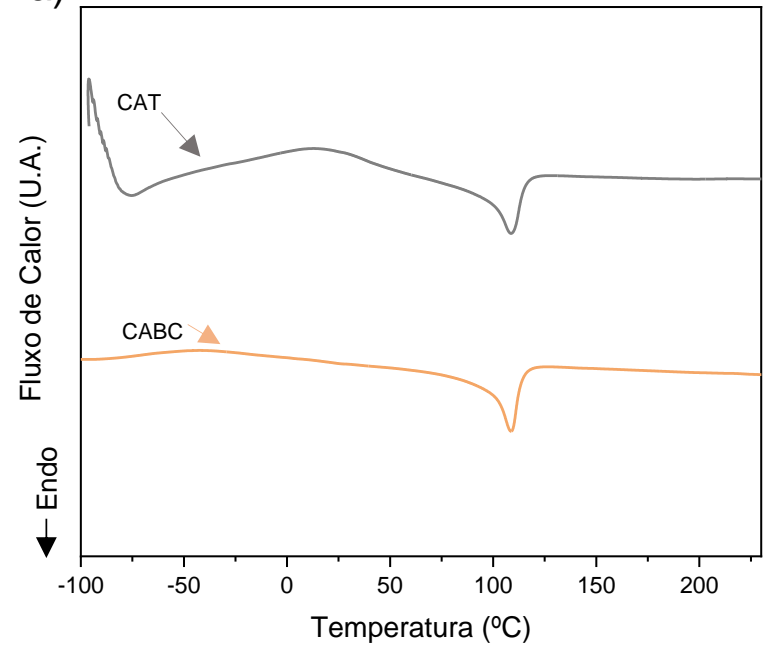

c)

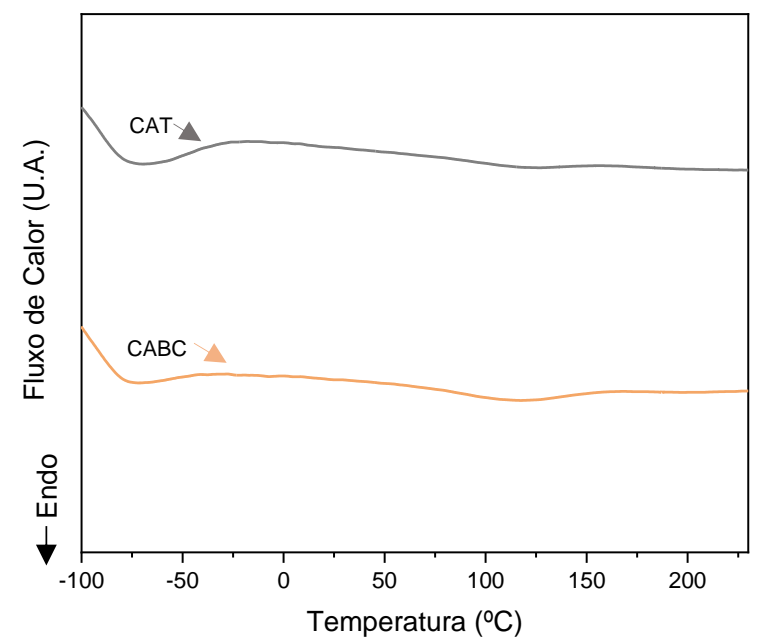

b)

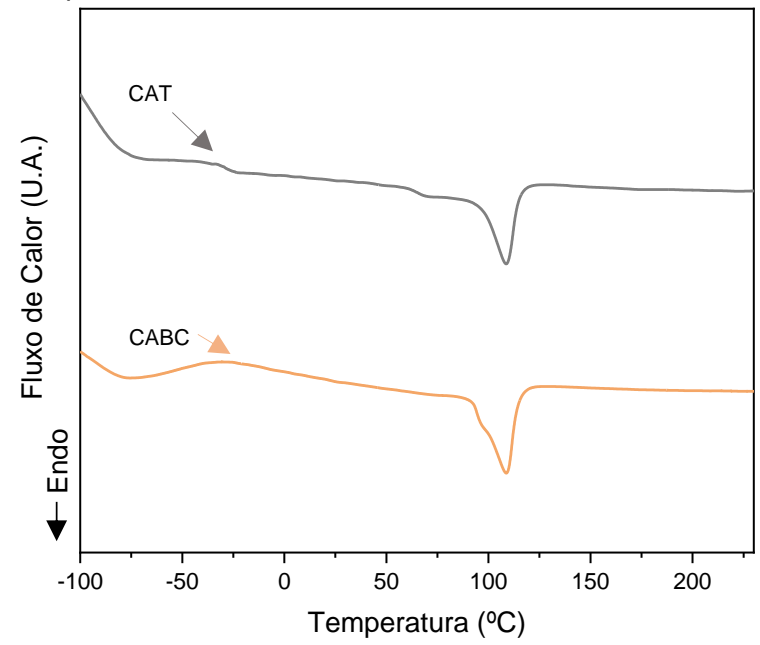

d)

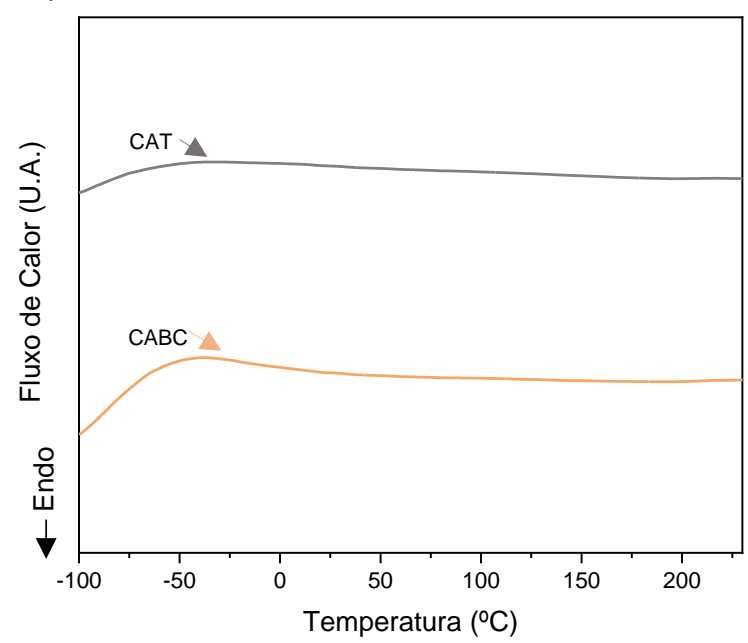

Fonte: Própria do autor.

Somente nestes resíduos foi possível separar manualmente os materiais das camadas 3 e 4 . Assim, o filme da camada 3 mostrou-se como o menos contaminado com outros materiais como adesivo e celulose.

A semelhança entre as curvas de DSC é bastante evidente, sobretudo na curva de segundo aquecimento (Figura 19b), o que permite inferir que a composição destes materiais é semelhante e tratando-se provavelmente do PEBD, uma vez que o sinal 
endotérmico em torno de $110{ }^{\circ} \mathrm{C}$ é característico deste polímero. As curvas de DSC da camada 4 dos resíduos CABC e CAT (Figuras 19c e 19d) também são bastante semelhantes entre si e não mostram sinais endotérmicos que evidenciam fusão. Assim, os polímeros que formam esta camada estão amorfos ${ }^{(49)}$.

Tabela 6 - Resultados de DSC das camadas poliméricas dos resíduos.

\begin{tabular}{llll}
\hline Resíduos & Camadas & Aquecimento & Picos \\
\hline CABE & 1 e 2 & primeiro & $100^{\circ} \mathrm{C}$ \\
CABE & 1 e 2 & segundo & $100^{\circ} \mathrm{C}$ \\
CABE & 3 e 4 & primeiro & - \\
CABE & 3 e 4 & segundo & - \\
& & & \\
CABC & 1 e 2 & primeiro & - \\
CABC & 1 e 2 & segundo & - \\
CABC & 3 e 4 & primeiro & $100^{\circ} \mathrm{C}$ \\
CABC & 3 e 4 & segundo & $100^{\circ} \mathrm{C}$ \\
CABC & 3 & primeiro & $100^{\circ} \mathrm{C}$ \\
CABC & 3 & segundo & $100^{\circ} \mathrm{C}$ \\
& & & \\
CABR & 1 e 2 & primeiro & $100^{\circ} \mathrm{C}$ \\
CABR & 1 e 2 & segundo & $100^{\circ} \mathrm{C}$ \\
CABR & 3 e 4 & primeiro & - \\
CABR & 3 e 4 & segundo & - \\
& & & \\
CAT & 1 e 2 & primeiro & - \\
CAT & 1 e 2 & segundo & - \\
CAT & 3 e 4 & primeiro & $100^{\circ} \mathrm{C}$ \\
CAT & 3 e 4 & segundo & $100^{\circ} \mathrm{C}$ \\
CAT & 3 & primeiro & $100^{\circ} \mathrm{C}$ \\
CAT & 3 & segundo & $100^{\circ} \mathrm{C}$ \\
\hline
\end{tabular}

Fonte: Própria do autor. 


\section{- Termogravimetria (TGA)}

As Figuras 20 a 22 apresentam uma comparação entre as curvas de TGA das camadas dos filmes poliméricos da etapa 1 do desenvolvimento experimental. A faixa de temperatura de decomposição térmica do material e o intervalo de decomposição de cada resíduo da etapa 1 estão apresentados na Tabela 7. A Figura 20 apresenta as curvas de TGA das camadas 1 e 2 dos resíduos.

Os termogramas de todos os resíduos para as camadas 1 e 2 apresentam dois patamares, sendo visualmente parecidos entre si para os resíduos CABE e CABR e para os resíduos CABC e CAT.

A decomposição térmica dos materiais dessas camadas ocorre inicialmente para os resíduos CABE e CABR em aproximadamente $204{ }^{\circ} \mathrm{C}$ e finaliza em cerca de $519^{\circ} \mathrm{C}$, enquanto que para os resíduos $\mathrm{CABC}$ e CAT a decomposição inicia em torno de $233^{\circ} \mathrm{C}$ e finaliza aproximadamente em $515^{\circ} \mathrm{C}$. Em adição a isso, a temperatura com maior taxa de perda de massa para os resíduos CABE e CABR estão em torno de $490 \stackrel{\circ}{\circ}$, e para os resíduos CABC e CAT estão próximas de $470 \stackrel{\circ}{\circ}$.

As derivadas do sinal de TG dos resíduos CABE, CABC e CAT apresentam um único pico, mas que pode sugerir dois estágios de decomposição. Por outro lado, o resíduo CABR apresenta nitidamente dois estágios de decomposição. Esses dados podem ser relacionados com os dados do FTIR para as mesmas camadas analisadas, exceto para o resíduo CABE. No FTIR o resíduo CABE apresenta bandas características do PEBD, e no DSC apresenta sinal endotérmico para esse mesmo polímero. Logo um único estágio apresentado no TGA, pode sugerir que seja composto de PEBD, mas pode também ser composta por outro material e ter ocorrido uma decomposição térmica simultânea. Em adição a isso, a temperatura de decomposição acima de $300{ }^{\circ} \mathrm{C}$ corresponde a decomposição do PEBD ${ }^{(46)}$. Para o resíduo CABR é sugerido no FTIR um copolímero com polietileno, e no DSC apresentam um pico endotérmico, compatível com PEBD, podendo justificar o estágio encontrado no TGA. 
Figura 20 - Curvas de TGA das camadas 1 e 2: a) todos os resíduos; b) CABE com a curva derivada; c) CABC com a curva derivada; d) CABR com a curva derivada; e) CAT com a curva derivada.
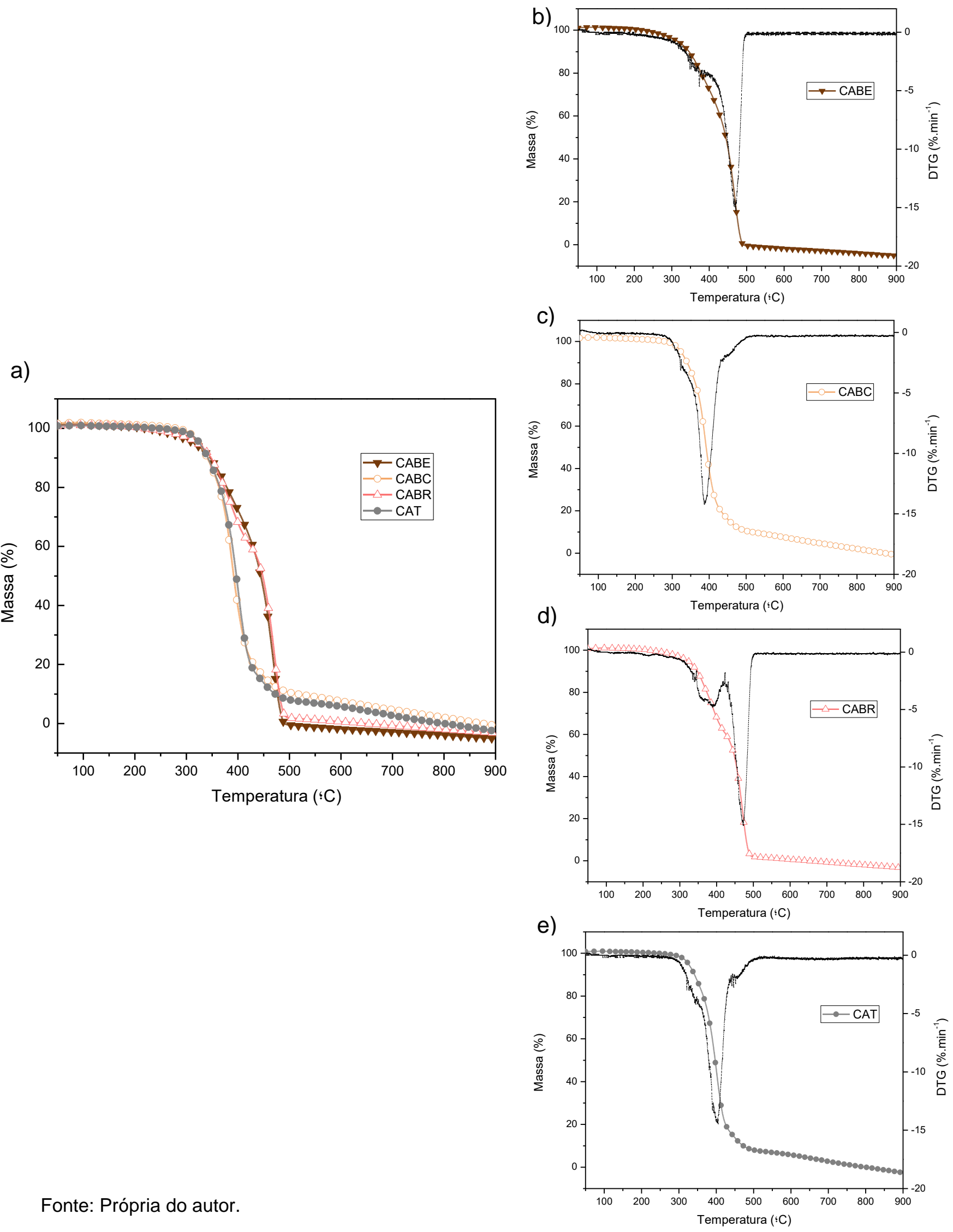

Fonte: Própria do autor. 
Nos termogramas foram observadas assimetrias que podem sugerir dois estágios para os resíduos CABC e CAT. Para o resíduo CABC os dados do FTIR e DSC indicam a presença de um copolímero baseado em polietileno.

A Figura 21 apresenta as curvas de TGA das camadas 3 e 4 dos resíduos. Os termogramas de todos os resíduos para as camadas 3 e 4 apresentam dois patamares, sendo visualmente parecidos entre si para os resíduos CABE e CABR e para os resíduos CABC e CAT.

A decomposição térmica dos materiais dessas camadas ocorre inicialmente para os resíduos CABE e CABR em aproximadamente $220{ }^{\circ} \mathrm{C}$ e finaliza em cerca de $400{ }^{\circ} \mathrm{C}$, enquanto que para os resíduos CABC e CAT a decomposição inicia em torno

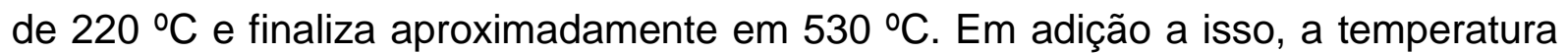
com maior taxa de perda de massa para os resíduos CABE e CABR estão em torno de $350^{\circ} \mathrm{C}$, e para os resíduos CABC e CAT estão próximas de $369 \stackrel{\circ}{\circ} \mathrm{C}$.

As derivadas dos sinais de TG para o resíduo CABE apresentam um único pico que indica somente um estágio de decomposição térmica para estes materiais. Por outro lado, os resíduos CABC e CAT são caracterizados por dois estágios de decomposição.

Esses dados corroboram com os dados do DSC para as mesmas camadas analisadas em CABE, CABC, CABR e CAT, levando em consideração que para o resíduo $\mathrm{CABR}$ pode ter ocorrido decomposição térmica simultânea. $\mathrm{O}$ resultado do FTIR não foi conclusivo na determinação dos materiais presentes para os resíduos CABE, CABC e CABR. Entretanto para o resíduo CAT foi sugerido no FTIR um copolímero, corroborando com os dois estágios apresentados no termograma.

Além do mais, a temperatura de decomposição acima de $300 \stackrel{\circ}{ } \mathrm{C}$ corresponde a decomposição do PEBD (50). 
Figura 21 - Curvas de TGA das camadas 3 e 4 de todos os resíduos: a) todos resíduos; b) CABE com a curva derivada; c) CABC com a curva derivada; d) CABR com a curva derivada; e) CAT com a curva derivada.

a)

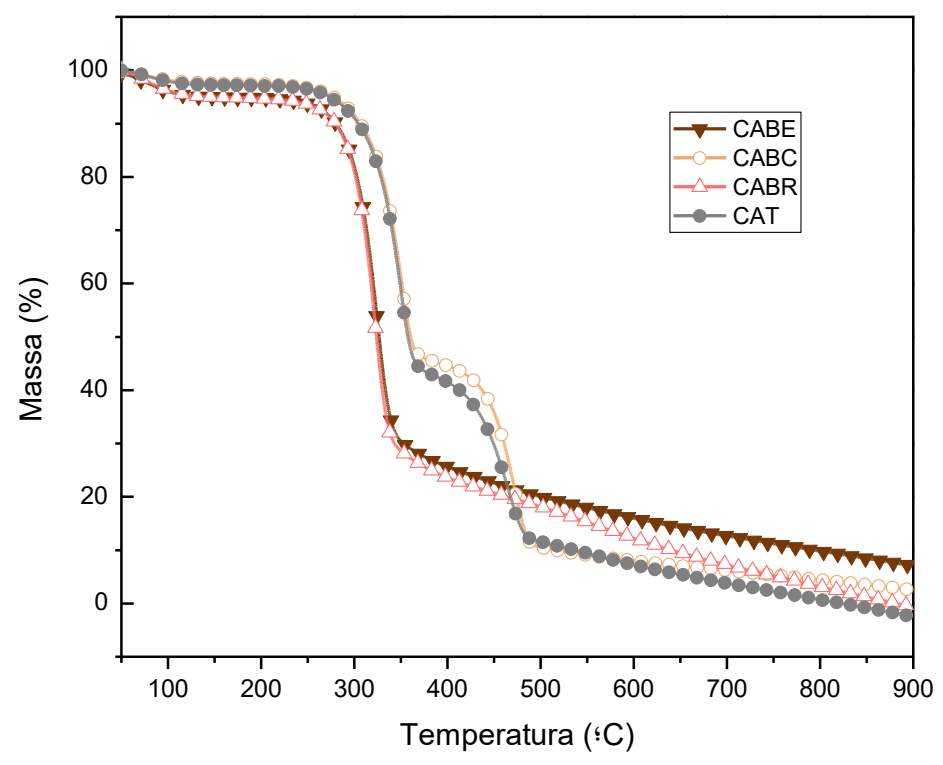

b)

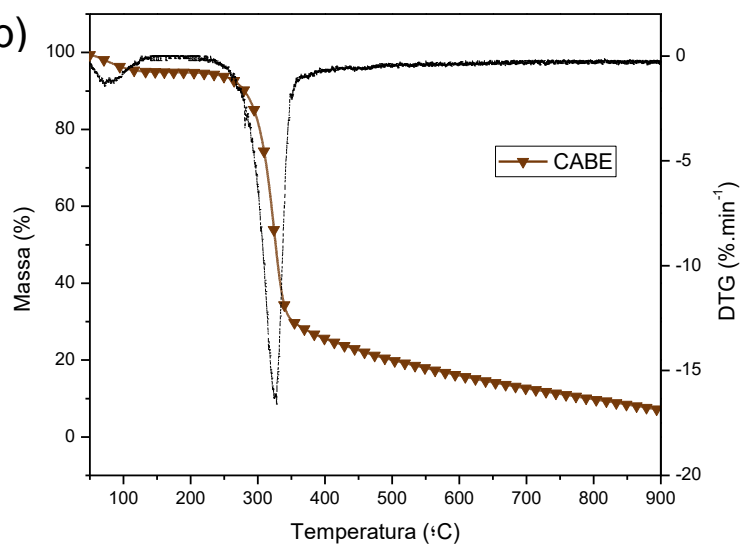

c)
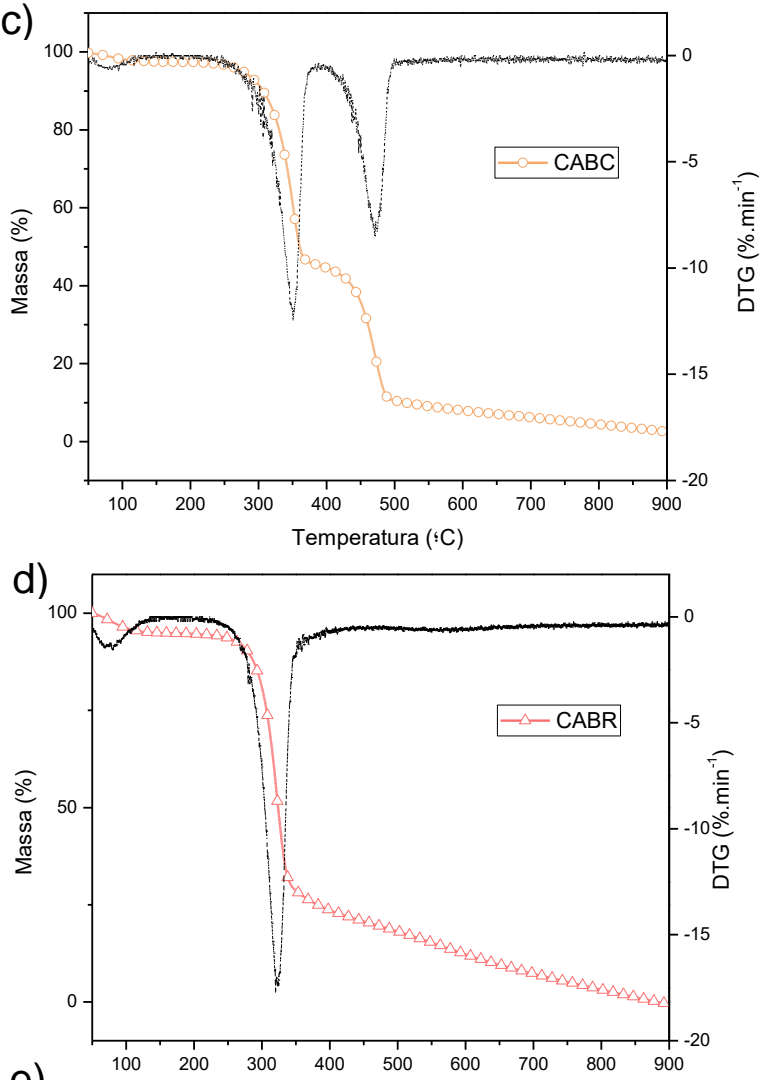

e)

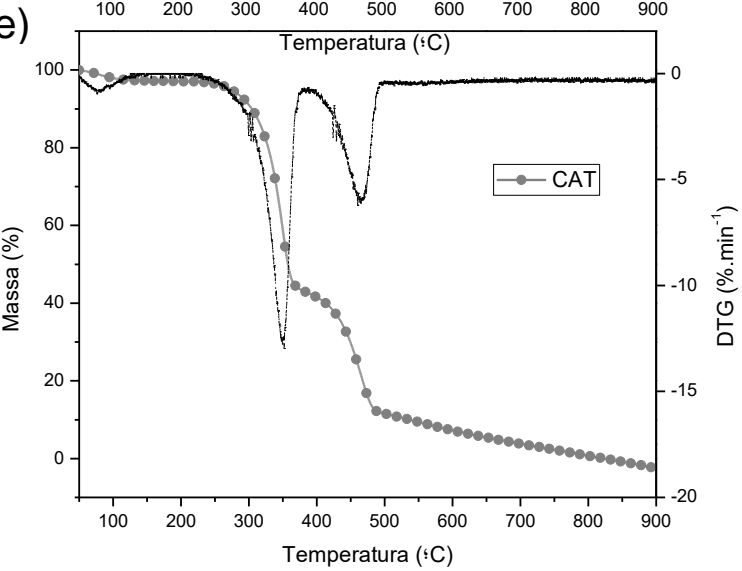

Fonte: Própria do autor. 
A Figura 22 apresenta as curvas de TGA da camada 3 dos resíduos CABC e CAT.

Figura 22 - Curvas de TGA da camada 3 dos resíduos: a) resíduos CABC e CAT; b) CABC com a curva derivada; c) CAT com a curva derivada.
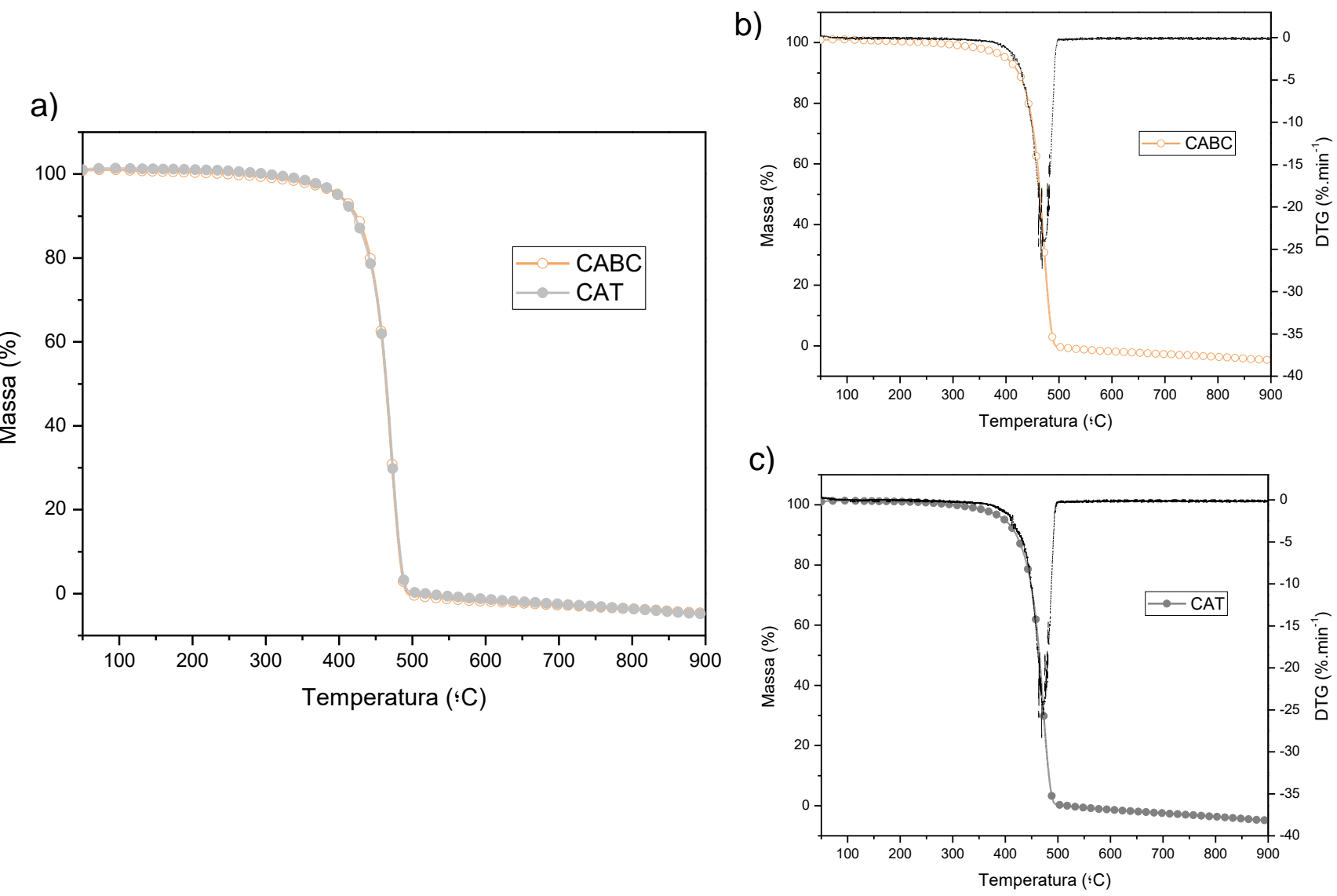

Fonte: Própria do autor.

Os termogramas dos resíduos CABC e CAT para a camada 3 apresentam um único estágio de decomposição térmica, sendo visualmente parecidos entre si.

A decomposição térmica ocorre inicialmente para ambos os resíduos em aproximadamente $291^{\circ} \mathrm{C}$ e finaliza em $531^{\circ} \mathrm{C}$. Em adição a isso, a temperatura com maior taxa de perda de massa está em torno de $493^{\circ} \mathrm{C}$.

As derivadas dos sinais de TG destes resíduos apresentam um único pico, indicando um único estágio de decomposição. Esse resultado não está de acordo com os resultados apresentados pelas Figuras $22 \mathrm{~b}$ e $22 \mathrm{c}$, onde há a presença de celulose. De acordo com os resultados de DSC há presença de dois picos endotérmicos quando esses polímeros são avaliados com e sem celulose (Figuras 19 e 20). Logo, essa discrepância dos resultados das Figuras 21c e 22e quando comparados às Figuras 
22b e 22c pode não estar relacionada à presença da celulose, e o que pode ter ocorrido possivelmente é uma decomposição térmica simultânea dos polímeros nas Figuras 22b e 22c, que apresentam uma composição mais pura, sem a presença de celulose. Quanto aos resultados do FTIR para o resíduo CABC foi notado bandas em regiões e intensidades que indicassem que pudesse ser um copolímero com PEBD e com base no resultado de DSC e TGA, indica que pode ser um copolímero com PEBD mesmo. No resultado de FTIR para o resíduo CAT foi sugerido um copolímero basedo em outro tipo de material polimérico, e corrobora com os dados de DSC e TGA em partes para esse material, visto que no DSC e TGA indicam um copolímero baseado em polietileno ${ }^{(52,24)}$.

Tabela 7 - Resultados de TGA das camadas poliméricas de cada resíduo.

\begin{tabular}{llll}
\hline Resíduos & Camadas & $\begin{array}{l}\text { Temperatura com maior } \\
\text { taxa de perda de massa } \\
\text { (ํ) })\end{array}$ & $\begin{array}{l}\text { Intervalo de } \\
\text { decomposição } \\
\text { térmica (C) }\end{array}$ \\
\hline \multirow{2}{*}{ CABE } & 1 e 2 & 490 & $204-519$ \\
& 3 e 4 & 350 & $220-400$ \\
CABC & 1 e 2 & 473 & $233-515$ \\
& 3 e 4 & 369 & $220-535$ \\
& 3 & 493 & $291-531$ \\
CABR & 1 e 2 & 494 & $204-519$ \\
& 3 e 4 & 350 & $220-400$ \\
& 1 e 2 & 471 & $233-515$ \\
CAT & 3 e 4 & 369 & $220-531$ \\
& 3 & 493 & $291-531$ \\
\hline
\end{tabular}

Fonte: Própria do autor. 


\section{- Análise Dinâmico-Mecânico (DMA)}

A análise de DMA foi realizada com o propósito de verificar diferenças nas propriedades térmicas e mecânicas dos resíduos, sobretudo no que diz respeitos as relaxações térmicas.

Na Figura 23 é feita uma comparação entre os módulos de armazenamento, módulos de perda e tangente delta dos resíduos.

Figura 23 - Resultados de DMA dos resíduos CABC, CABE CABR e CAT: a) módulo de armazenamento: E'; b) módulo de perda: E" e c) fator de perda: Tan $\delta$.

a)

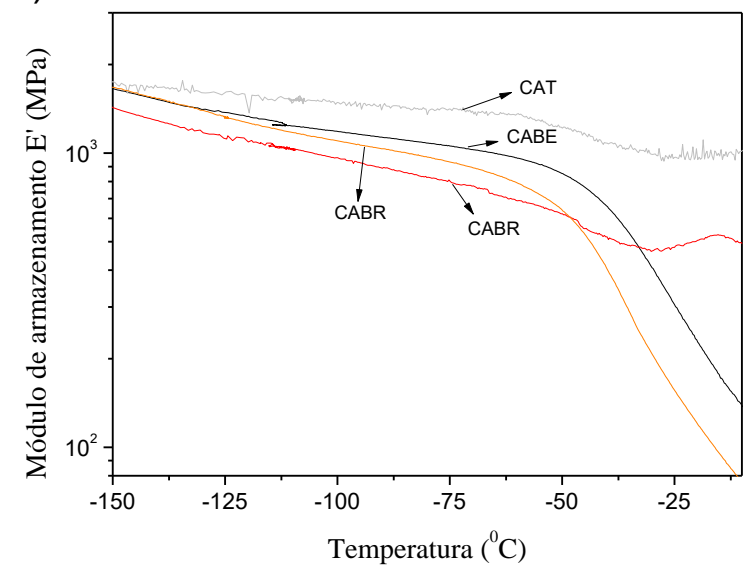

b)

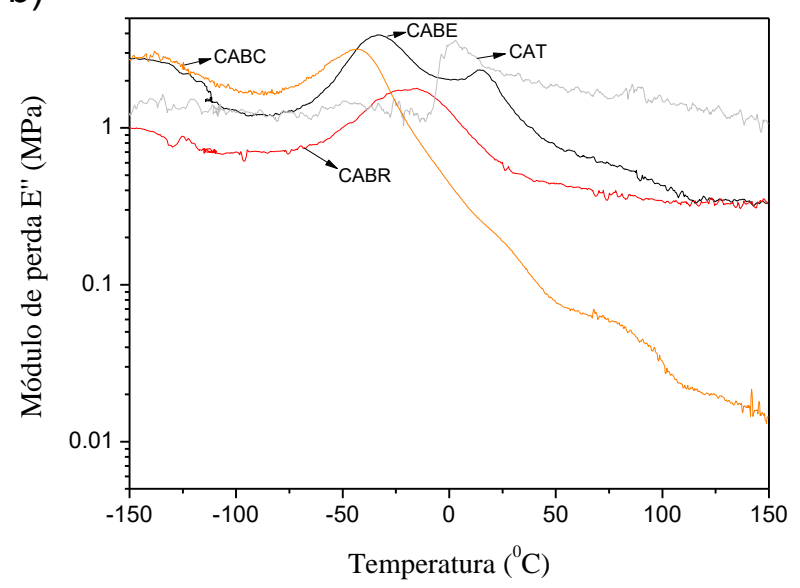

c)

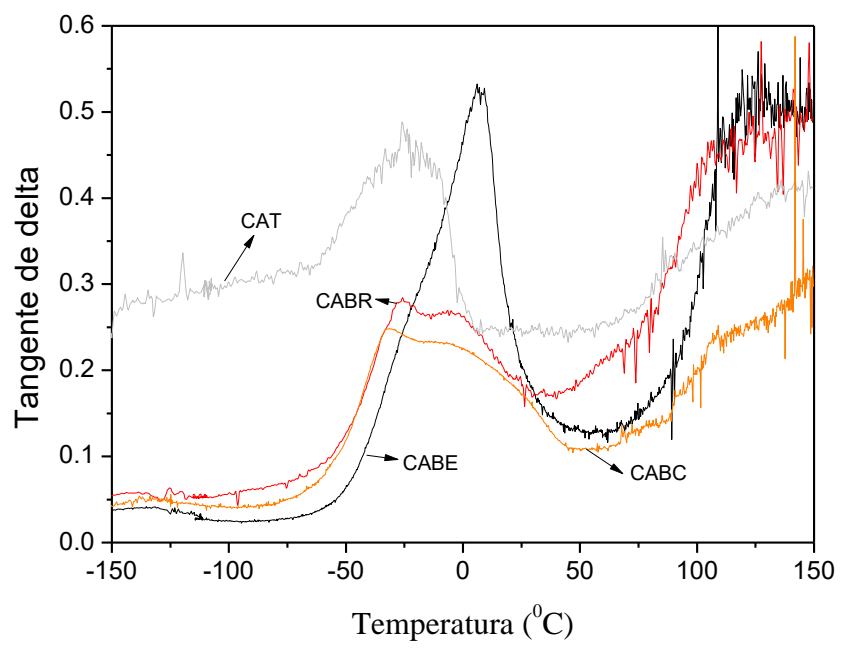

Fonte: Própria do autor.

Nota-se que o módulo de armazenamento (Figura 23a) dos resíduos em baixas temperaturas apresenta valores por volta de $10^{9} \mathrm{~Pa}$, caracterizando-os como rígidos até a temperatura de aproximadamente $-50 \stackrel{\circ}{\circ}$. Após esta temperatura o módulo de 
armazenamento diminui, indicando a ocorrência de uma relaxação térmica que pode ser atribuída à transição vítrea do material.

A partir das curvas de módulo de perda e fator de perda (Figuras 23b e 23c) verifica-se que a transição atribuída à transição vítrea dos polímeros se extende de 50 a $50 \stackrel{\circ}{ } \mathrm{C}$ e apresenta diferenças entre os resíduos. As curvas de fator de perda também mostram um aumento de valor em $100^{\circ} \mathrm{C}$ com subsequente aumento do ruído no sinal, que por sua vez deve estar associado à fusão do polímero.

As relaxações verificadas são características do polietileno e confirmam os resultados descritos anteriormente que indicam que os resíduos devem ser compostos predominantemente por este polímero, contendo outros componentes poliméricos em menor quantidade ${ }^{(45)}$.

\subsection{Processamento dos materiais (etapa 2)}

Nesta etapa os resíduos foram processados pela técnica de hidro-polpação, com o objetivo de separar a celulose dos demais componentes poliméricos, que foi a primeira opção de escolha, em função de não precisar de aditivos químicos e ser um processo relativamente simples e barato. A separação da celulose dos filmes poliméricos para todos os resíduos foi bem-sucedida, conforme resultados apresentados nas Figuras 24 a 26.

Na Figura 24 são apresentados os valores do teor de celulose que foi recuperada para cada resíduo (Figura 24a) e o teor de polímeros, referentes as camadas 1, 2 e 3 de cada material, que permaneceu com celulose residual (Figura 24b) após o processo de hidro-polpação. 
Figura 24 - Teor de celulose recuperada e dos residuais, após o processo de hidro-polpação dos resíduos: a) celulose recuperada e b) polímeros residuais.

a)

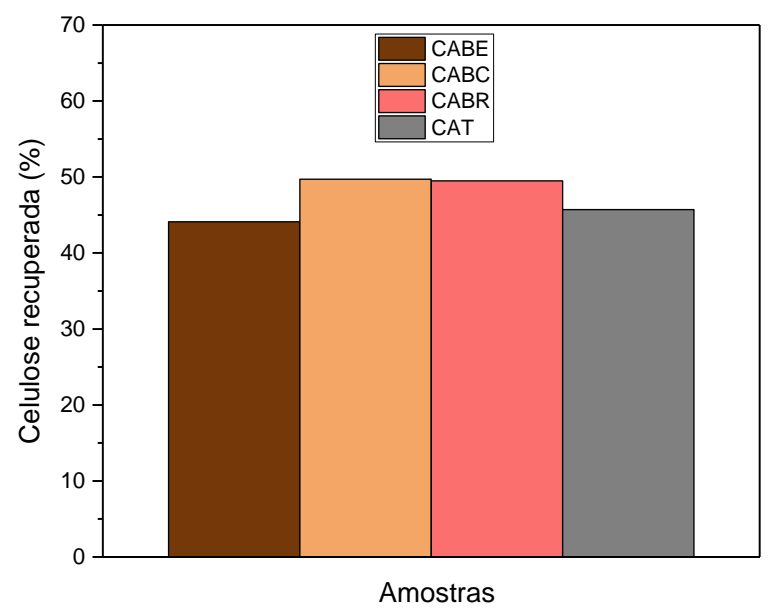

Fonte: própria do autor. b)

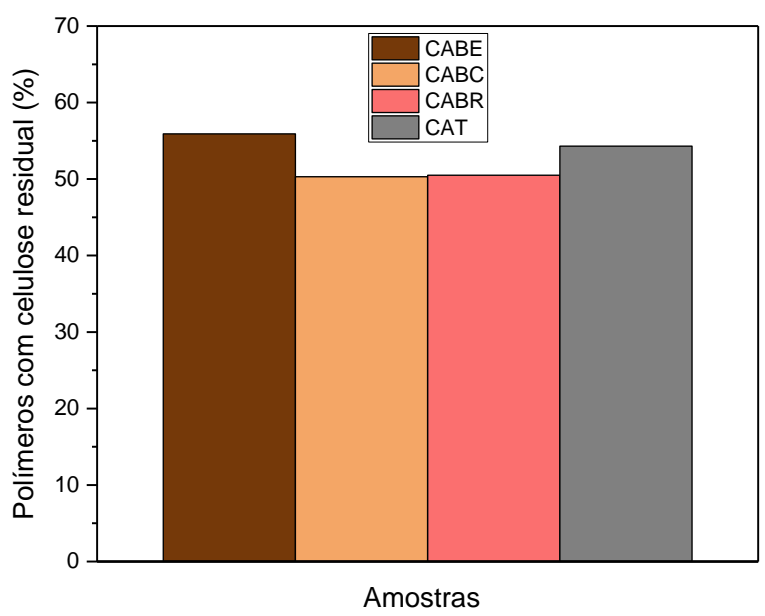

Nota-se que, após o processo de hidro-polpação, os resíduos CABC e CABR apresentaram uma porcentagem de recuperação de celulose um pouco maior (em torno de 50\%) e em consequência disso, uma quantidade um pouco menor de polímeros remanescentes em cada resíduo, quando comparados aos resíduos CABE e CAT. Essa diferença de resultado apresentado não é considerada significativa, mas pode ser atribuída ao tipo de material polimérico de cada camada, sua espessura e como foram laminadas no processo de fabricação.

Na Figura 25 é mostrada uma imagem da celulose que foi recuperada após a hidro-polpação de todos os resíduos.

Figura 25 - Imagem da celulose recuperada.

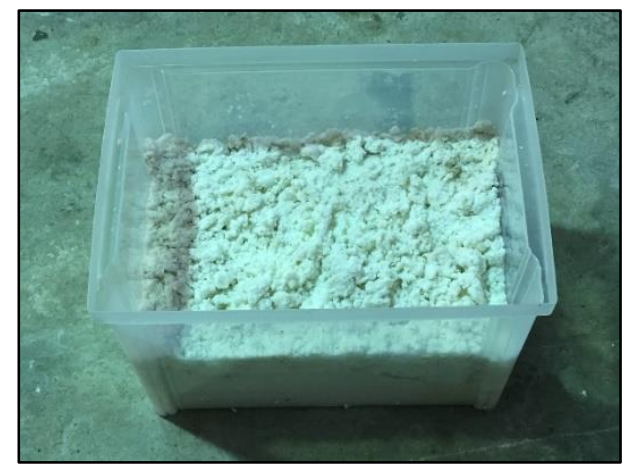

Fonte: própria do autor. 
A celulose absorve uma quantidade significativa de água durante o processo de hidro-polpação, necessitando um tempo significativo de secagem ao ar livre e posteriormente em estufa a $100 \stackrel{\circ}{C}$ para atingir uma massa final estável, a qual foi de aproximadamente em $50 \%$ da massa inicial dos resíduos.

A Figura 26 apresenta imagens de cada resíduo em frente e verso, antes e após o processo de hidro-polpação para a separação da celulose.

Figura 26 - Imagens dos resíduos em frente e verso: a) antes do processo de hidro-polpação e b) após o processo de hidro-polpação.

a) Antes da hidro-polpação

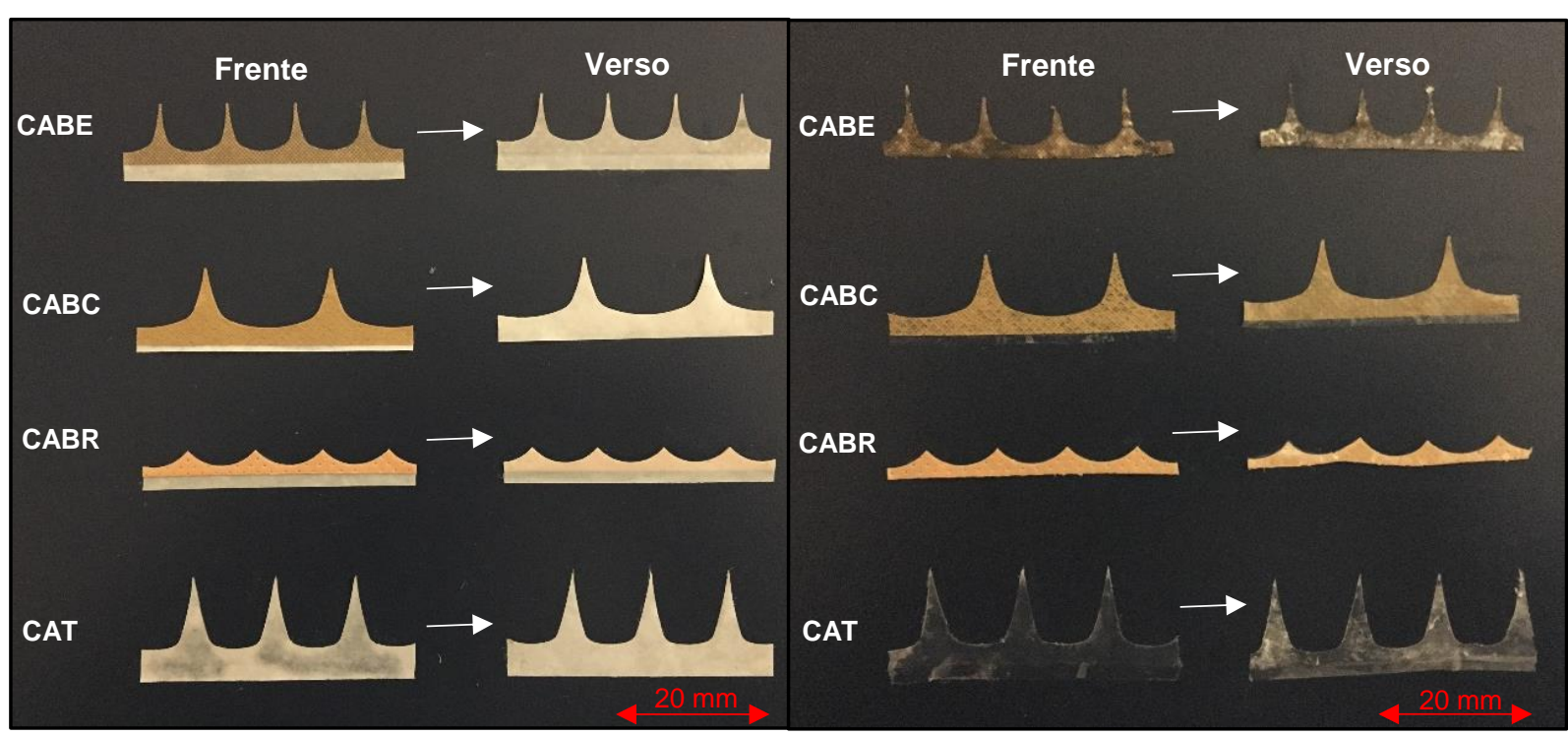

Fonte: própria do autor.

Mediante análise visual, os resíduos CABE e CAT permaneceram com maior teor de celulose residual, enquanto nos resíduos $C A B C$ e CABR a celulose foi extraída com maior eficiência. Isto é confirmado pelo teor de celulose recuperada que foi anteriormente determinado (Figura 26). 
Após a separação da celulose dos polímeros de cada resíduo, os materiais poliméricos remanescentes na forma de filmes foram submetidos à moagem. A Figura 27 apresenta imagens dos materiais.

Figura 27 - Resíduos poliméricos após separação da celulose e moagem: a) CABE; b) CABC; c) CABR e d) CAT.

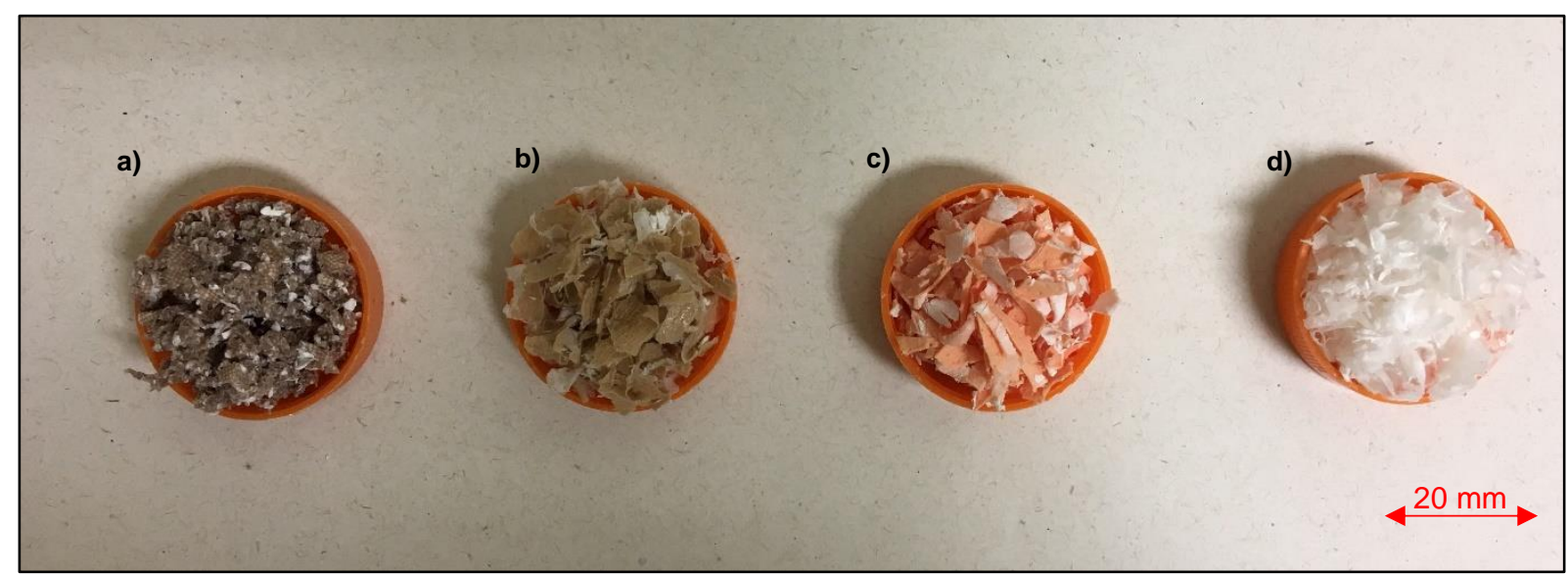

Fonte: própria do autor.

A moagem dos resíduos foi necessária para submeter os materiais ao processamento termomecânico por extrusão. O resultado da moagem resultou em partículas de filmes com tamanho reduzido, os quais foram similares entre todos os resíduos, com exceção do resíduo CABE, em que foi notado partículas de filmes menores comparado aos demais. Novamente esse resultado pode ser atribuído ao tipo de material polimérico de cada camada, sua espessura e como foram laminadas no processo de fabricação. 
Na sequência os materiais foram submetidos à extrusão. A Figura 28 apresenta fotos dos resíduos CABE e CAT após este procedimento.

Figura 28 - Resíduos após extrusão e peletização: a) CABE extrudado e CABE peletizado; b) CABC extrudado e CABC peletizado; c) CABR extrudado e CABR peletizado; d) CAT extrudado e CAT peletizado.

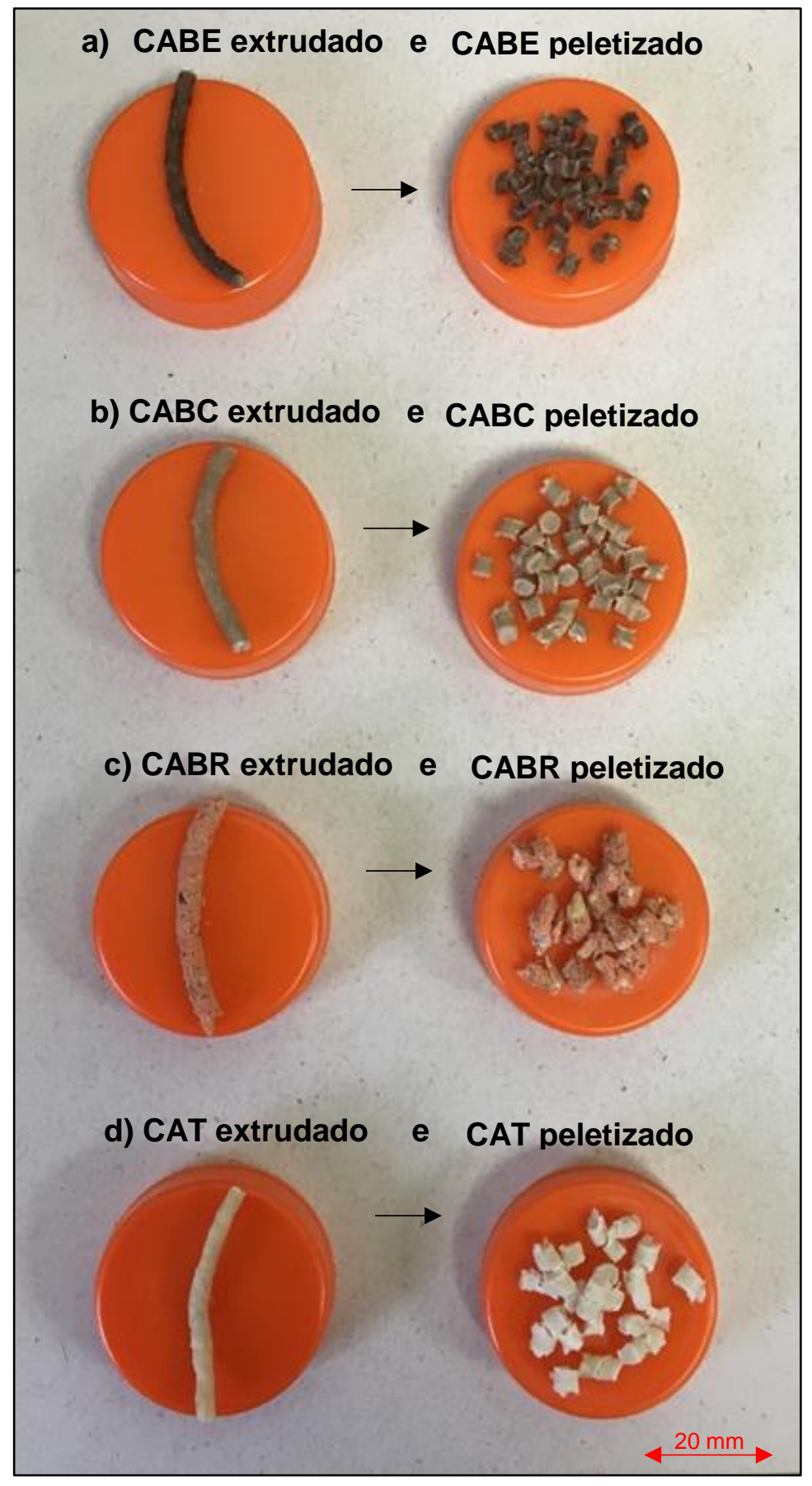

Fonte: própria do autor. 
O resultado da extrusão mostra que, após a mistura termomecânica dos componentes para cada resíduo individualmente, a reciclagem foi bem sucedida, pois foram passíveis de serem processados termomecanicamente e sendo estes materais assim caracterizados como reciclados.

Após esse procedimento, os materiais foram submetidos à moldagem por injeção. A Figura 29 apresenta foto do resíduo CABE após a injeção.

Figura 29 - Resíduo CABE após injeção.

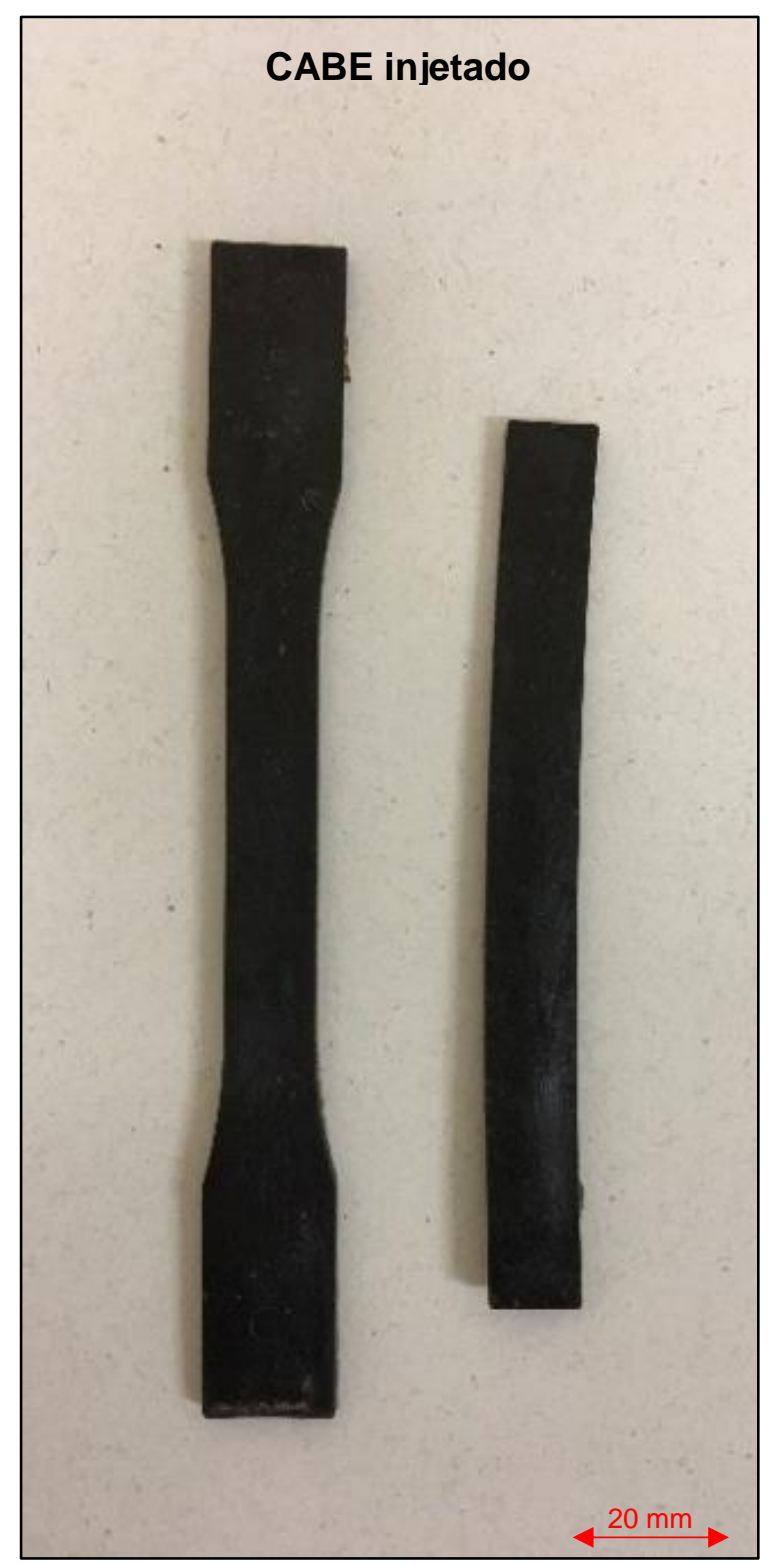

Fonte: própria do autor.

Verifica-se por meio da moldagem por injeção que foram produzidos corpos de prova para o resíduo CABE após extração da celulose com preenchimento completo 
das cavidades. Entretanto, foram verificadas dificuldades durante 0 seu processamento. Em alguns corpos de prova foi observado um aumento de volume na região central, podendo estar relacionado ao aprisionamento de gás produzido por uma possível decomposição do material durante a injeção. Para os demais resíduos, a moldagem por injeção se mostrou inviável devido à grande liberação de voláteis, provavelmente liberados pela decomposição térmica de algum componente do resíduos, e impossibilitando à confecção dos corpos de prova.

\subsection{Caracterização dos materiais processados (etapa 3)}

Embora o processamento dos resíduos por meio de moldagem por injeção tenha apresentado dificuldades, os corpos de prova produzidos a partir do resíduo CABE foram utilizados para caracterizações de propriedades do material reciclado após as etapas de processamento termomecânico.

\section{- Espectroscopia no Infravermelho por Transformada de Fourier (FTIR)}

A Figura 30 apresenta o resultado de FTIR, pelo método ATR do resíduo CABE.

Figura 30 - Espectro de FTIR (ATR), das camadas dos filmes poliméricos do resíduo CABE.

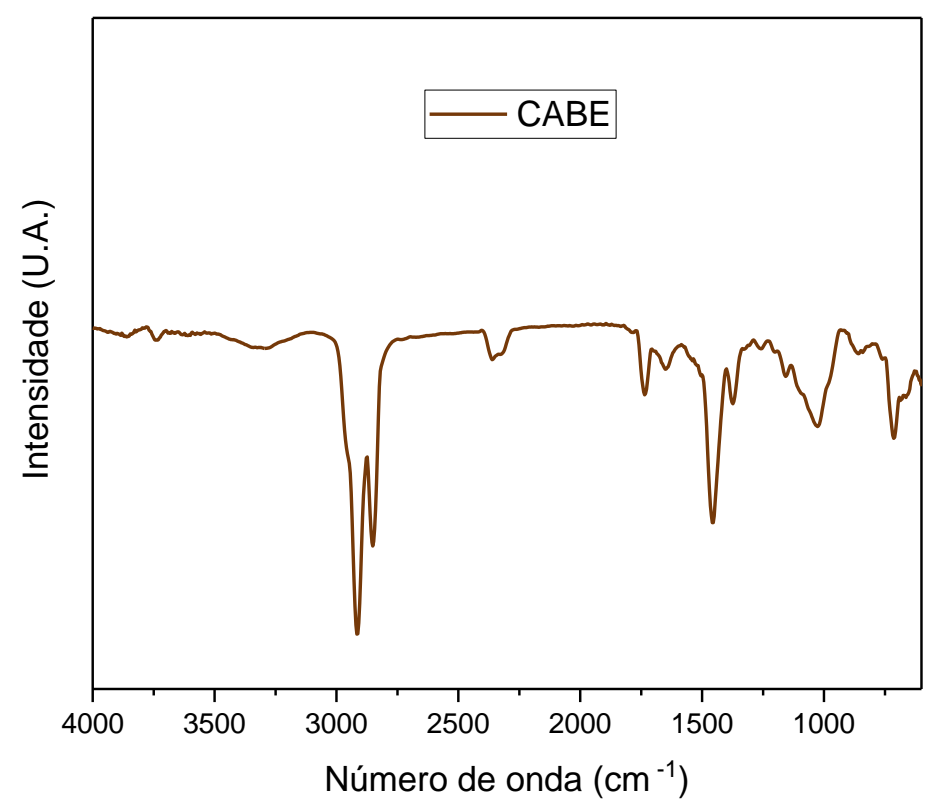

Fonte: Própria do autor. 
A Tabela 8 lista as bandas do resíduo CABE em suas respectivas camadas.

Tabela 8 - Resultados de FTIR das camadas poliméricas do resíduo CABE.

\begin{tabular}{|c|c|c|c|c|}
\hline Material & Camadas & $\begin{array}{l}\text { Número de Onda } \\
\left(\mathrm{cm}^{-1}\right)\end{array}$ & $\begin{array}{l}\text { Grupo } \\
\text { Funcional }\end{array}$ & Modo Vibracional \\
\hline \multirow[t]{7}{*}{ CABE } & 1,2 e 3 & $3000-2800$ & $\mathrm{C}-\mathrm{H}$ & $\begin{array}{l}\text { Deformações axiais simétrica e } \\
\text { assimétrica de } \mathrm{CH}_{2} \text {. }\end{array}$ \\
\hline & & $1750-1735$ & $\mathrm{C}=\mathrm{O}$ & Deformação de $\mathrm{C}=\mathrm{O}$ de éster. \\
\hline & & $1680-1600$ & $\mathrm{C}=\mathrm{C}$ & Deformação simétrica de $\mathrm{CH}_{3}$ \\
\hline & & $1500-1400$ & $\mathrm{C}-\mathrm{H}$ & $\begin{array}{l}\text { Deformação angular simétrica e } \\
\text { assimétrica de } \mathrm{CH}_{2} \text { e } \mathrm{CH}_{3} \text {. }\end{array}$ \\
\hline & & 1371 & $\mathrm{C}-\mathrm{H}$ & Deformação simétrica de $\mathrm{CH} 3$ \\
\hline & & Próximo à 1000 & $\mathrm{C}-\mathrm{H}$ & $\begin{array}{l}\text { Deformação angular simétrica } \\
\text { de } \mathrm{CH} \text { fora do plano. }\end{array}$ \\
\hline & & Próximo à 720 & $\mathrm{C}-\mathrm{H}$ & $\begin{array}{l}\text { Deformação angular assimétrica } \\
\text { de } \mathrm{CH}_{2} \text {. }\end{array}$ \\
\hline
\end{tabular}

Fonte: Própria do autor.

O resíduo $\mathrm{CABE}$, após processamento, apresenta bandas de FTIR características do PEBD e de celulose (Figura 16), além de outras bandas que podem estar associadas a modos distintos de absorção para outros tipos de ligações. Estas bandas podem ser atribuídas a grupos químicos como acrílicos e a celulose residual do material que se apresenta como um copolímero com o polietileno. Nas camadas 1 e 2, analisadas juntas e antes do processamento, foram identificadas bandas características de PEBD. Já quando foram analisadas as camadas 3 e 4, não foi possível observar bandas típicas do PEBD. 


\section{- Calorimetria Exploratória Diferencial (DSC)}

A Figura 31 apresenta os resultados do resíduo CABE, após o processamento, termomecânico (contemplando as camadas 1, 2 e 3).

Figura 31 - Curvas de DSC do resíduo CABE.

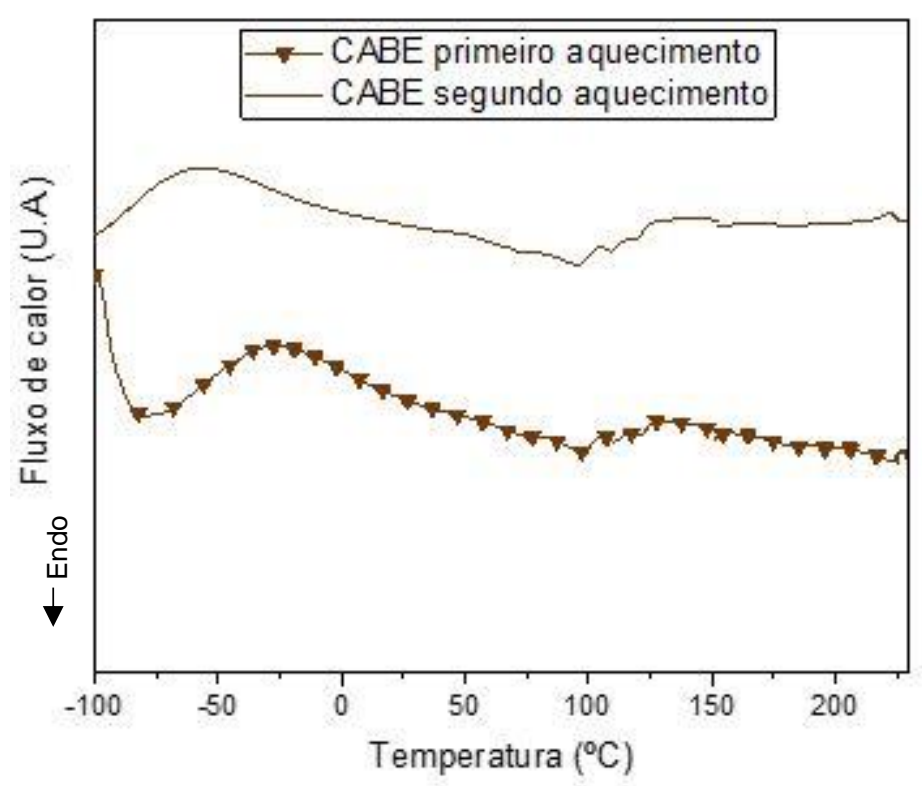

Fonte: Própria do autor.

Na curva de DSC de primeiro aquecimento do resíduo CABE (Figura 31) notase um sinal endotérmico de baixa intensidade por volta de $100 \stackrel{\circ}{\mathrm{C}}$, porém os patamares desse sinal denotam a existência de heterogeneidade de cristais formados por cadeias de diferentes tamanhos ou com características distintas que apresentam ponto de fusão, assim como na Figura 17b. Na curva de segundo aquecimento deste resíduo (Figura 31) o sinal em torno de $100 \stackrel{\circ}{\mathrm{C}}$ observado no primeiro aquecimento, praticamente desaparece. Isto pode ser consequência de componentes do material que sofreram decomposição térmica ou que fundiram e não recristalizaram durante o resfriamento que precede o segundo aquecimento.

O comportamento do primeiro e segundo aquecimento deste resíduo na etapa 1 (Figura 17a) e após o processamento, etapa 3 (Figura 31) é idêntico, pois ambos os picos endotérmicos observados no primeiro aquecimento praticamente desaparecem no segundo aquecimento. Esse comportamento pode também ter ocorrido em função 
da decomposição térmica do material ou da fusão e não recristalização durante o resfriamento anterior ao segundo aquecimento.

\section{-Termogravimetria (TGA)}

A Figura 32 apresenta a curva de TGA do resíduo CABE após a injeção.

Figura 32 - Curva de TGA do resíduo CABE com a derivada após o processamento por injeção.

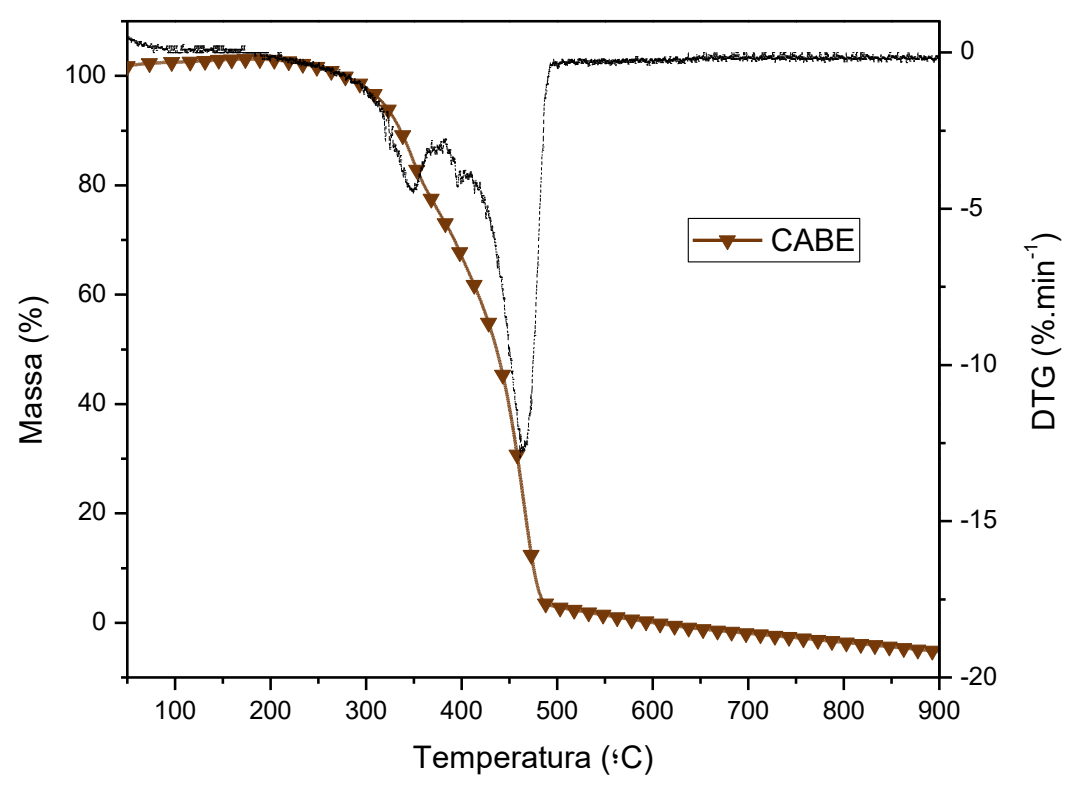

Fonte: Própria do autor.

O resíduo CABE apresenta dois estágios de decomposição térmica, assim como é apresentado para esse material não processado (Figuras 20b e Figura 21b).

A decomposição térmica dos materiais dessas camadas ocorre inicialmente em aproximadamente $204^{\circ} \mathrm{C}$ e finaliza em $519^{\circ} \mathrm{C}$, um comportamento bem parecido para este material antes do processamento termomecânico (Figura 20b). Em adição a isso, a temperatura com maior taxa de perda de massa está em torno de $490{ }^{\circ} \mathrm{C}$, comportamento idêntico deste material antes de ser processado (Figura 20b). 
As derivadas do sinal de TG apresentam um único pico que sugere dois estágios de decomposição, a exemplo do relatado previamente (Figura 20b e Figura 21b).

\section{- Microscopia Eletrônica de Varredura (MEV)}

Na Figura 33 são apresentadas as imagens de MEV da seção transversal do resíduo $\mathrm{CABE}$.

Figura 33 - Imagens de MEV do resíduo CABE em ampliação de 40 vezes: a) região periférica e b) região central.

a)

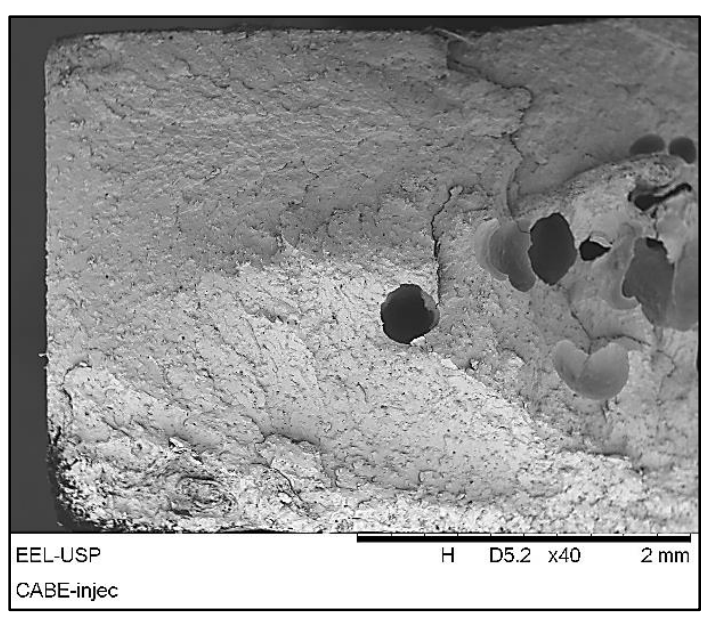

b)

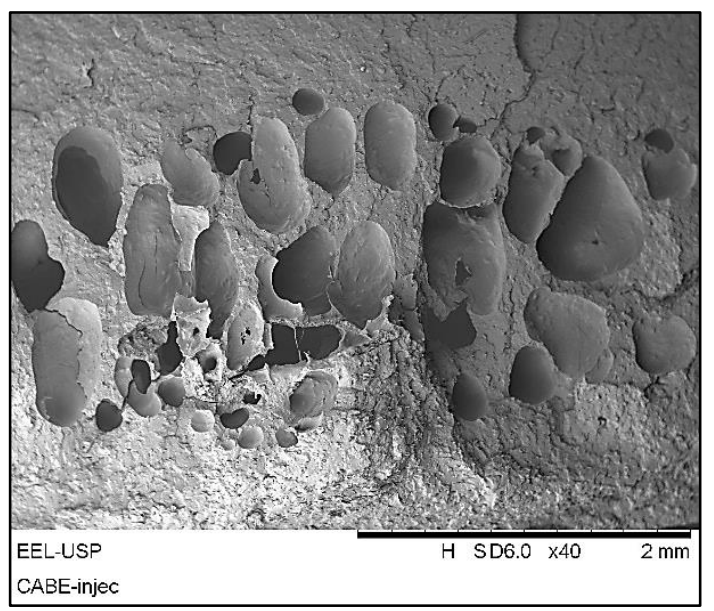

Fonte: Própria do autor.

Na região periférica do material (Figura 33a) pode-se observar uma estrutura mais contínua com menor presença de cavidades e orifícios, enquanto na região central a formação acentuada de macro-porosidades é observada. Estes defeitos são ocasionados pela liberação de voláteis durante o processo de injeção, confirmando o aumento da região central que foi observado nos corpos de prova obtidos na moldagem por injeção. Provavelmente estes voláteis são oriundos principalmente da decomposição da fração de adesivos do resíduo que poderiam se prender à rosca e ao canhão de injeção e devido ao maior tempo de residência no equipamento em altas temperaturas sofreriam decomposição térmica. $O$ fato dos defeitos estarem concentrados na região central do corpo de prova pode ser explicado pelo fluxo que o polímero fundido descreve ao entrar na cavidade do molde, resfriando-se mais 
rapidamente na região em contato com a parede do molde e mantendo-se mais quente e mais fluido em seu interior.

Na Figura 34 são apresentadas imagens de MEV das regiões periférica e central do resíduo CABE em maior amplificação.

Figura 34 - Imagens de MEV do resíduo CABE: a) da região central (x 250); e da região periférica b) (x 200); c) (x 5000) e d) (x 10000).

a)

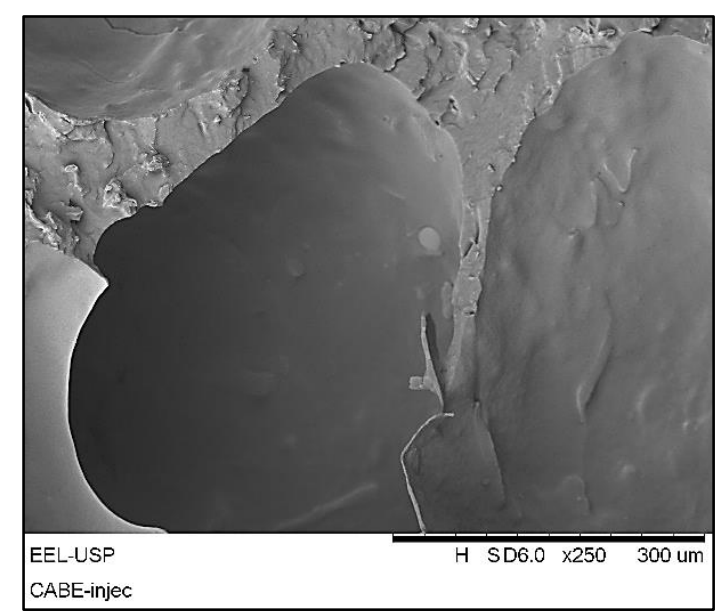

c)

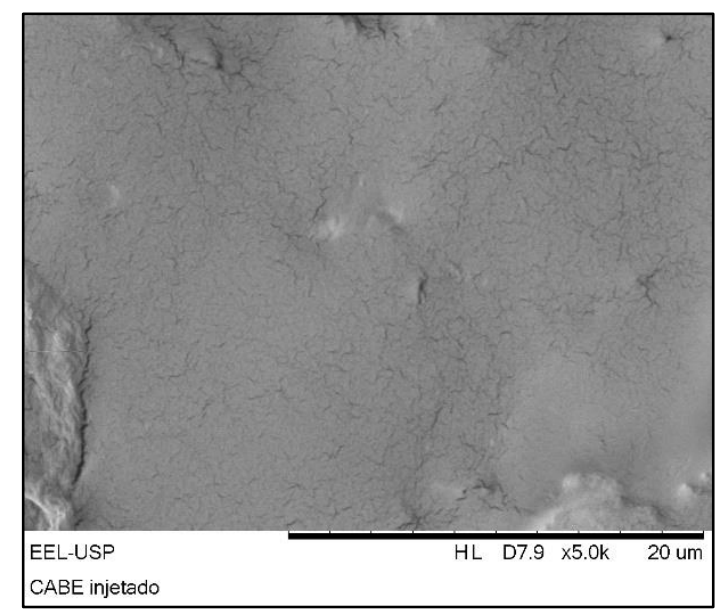

b)

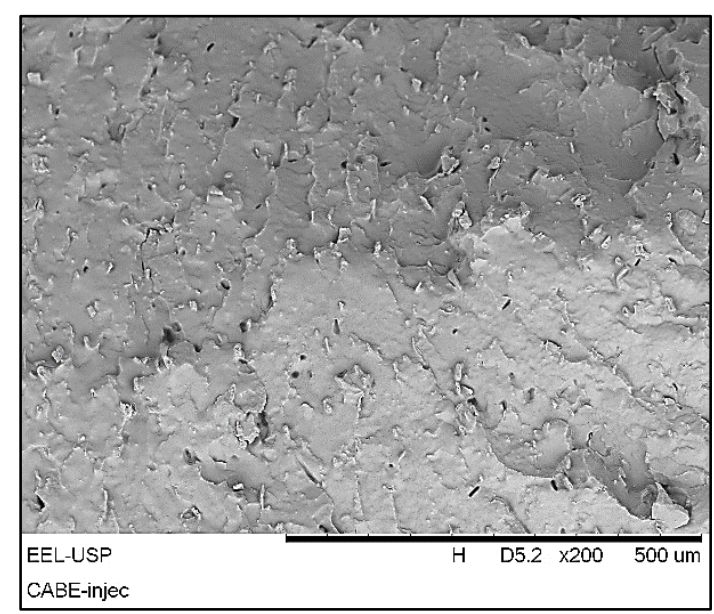

d)

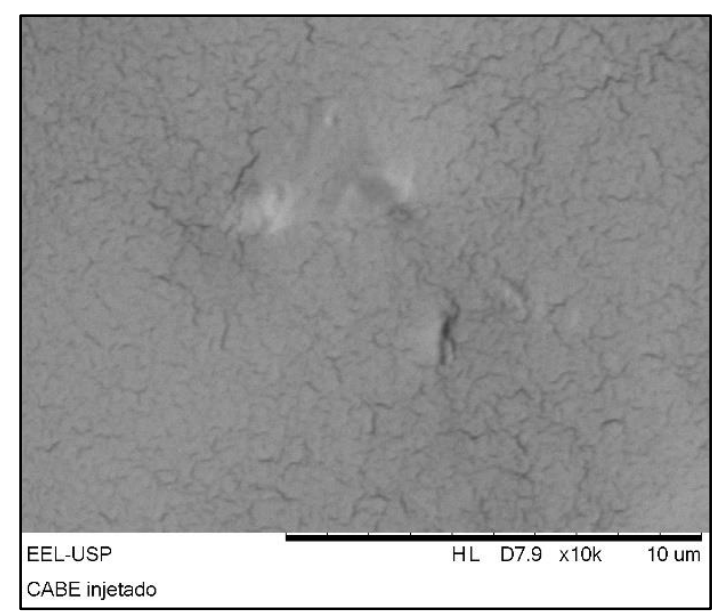

Fonte: Própria do autor.

$\mathrm{Na}$ imagem panorâmica de MEV, no modo elétrons retro-espalhados da região central (Figura 34a) pode-se notar que as porosidades estão vazias e que podem ter sido possivelmente provocados pela saída de gases em decorrência da decomposição do material durante o processo da injeção. 
Na Figura 34b nota-se uma maior compactação do material na região periférica. Já nas Figuras 34c-d pode-se observar, com um aumento maior, um contraste uniforme, o que pode sugerir uma superfície regular do material.

\section{- Análise Dinâmico-Mecânico (DMA)}

A análise de DMA permitiu determinar as temperaturas de relaxação para o resíduo CABE após o processamento termomecânico, a partir dos valores do módulo de armazenamento (E'), do módulo de perda (E') e do fator de perda (tan $\delta)$. A Figura 35 mostra a comparação das curvas das três propriedades avaliadas para esse resíduo.

Figura 35 - Resultado de DMA do resíduo CABE: a) módulo de armazenamento: E'; b) módulo de perda: E" e c) fator de perda: Tan $\delta$.

a)

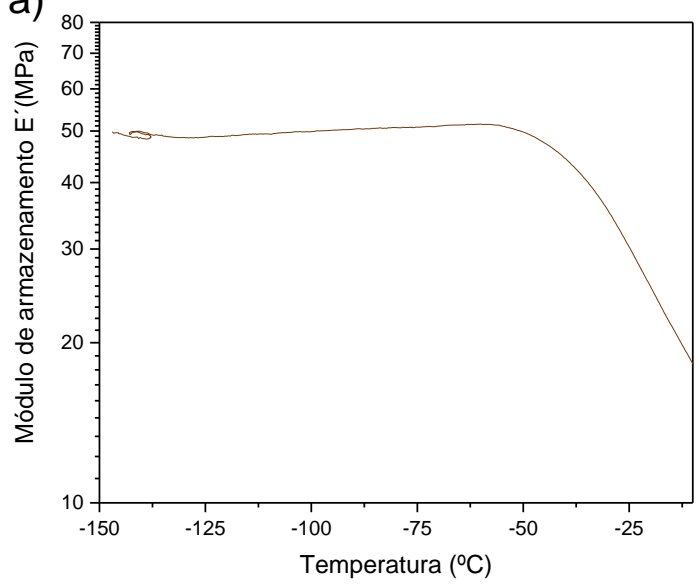

b)

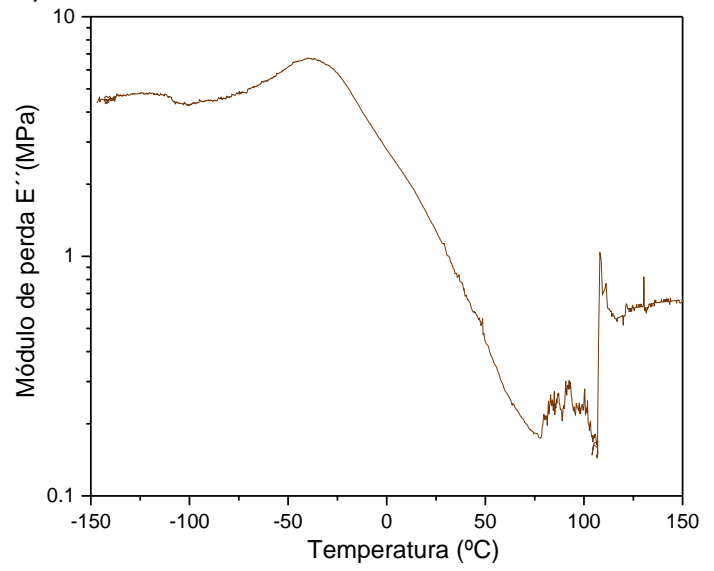

c)

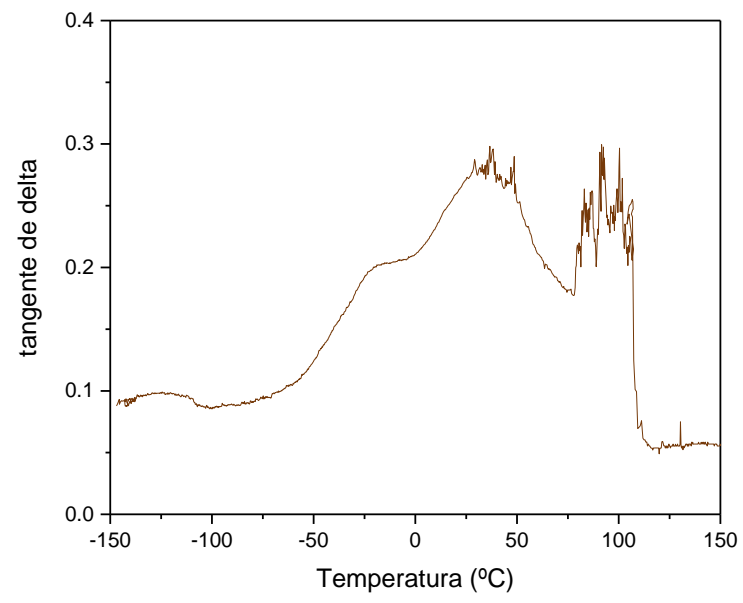

Fonte: Própria do autor. 
A relaxação referente à fusão dos polímeros ocorreu próximo a $100{ }^{\circ} \mathrm{C}$ para as três propriedades avaliadas nessa análise (Figura 35a - Figura 35c). Já a temperatura de relaxação relacionada à transição vítrea foi observada próximo a $-50 \stackrel{\circ}{\mathrm{C}}$ para as três propriedades avaliadas.

Pela composição do material, podendo ser basicamente composta de polietileno/polipropileno, a temperatura de fusão próxima a $100 \stackrel{\circ}{\circ}$ pode estar relacionada à temperatura de fusão do polímero PEBD e a temperatura de fusão relacionada ao polímero $\mathrm{PP}$, devendo ocorrer em $160^{\circ} \mathrm{C}$, não pôde ser identificada. Já a transição vítrea em $-50 \stackrel{\circ}{ } \mathrm{C}$ pode também estar relacionado ao PEBD. Assim, mesmo havendo a possibilidade da presença de PP na composição, o PEBD deve ser 0 componente polimérico majoritário do resíduo ${ }^{(45)}$.

\section{- Ensaio de Tração}

A Figura 36 apresenta os resultados do ensaio de tração referente ao resíduo CABE após processamento. Vale salientar que a numeração dos corpos de prova na Figura 36 é relativa à ordem crescente de obtenção destes durante o processo de injeção.

Figura 36 - Curvas de tensão-deformação dos oitos corpos de prova do resíduo CABE.

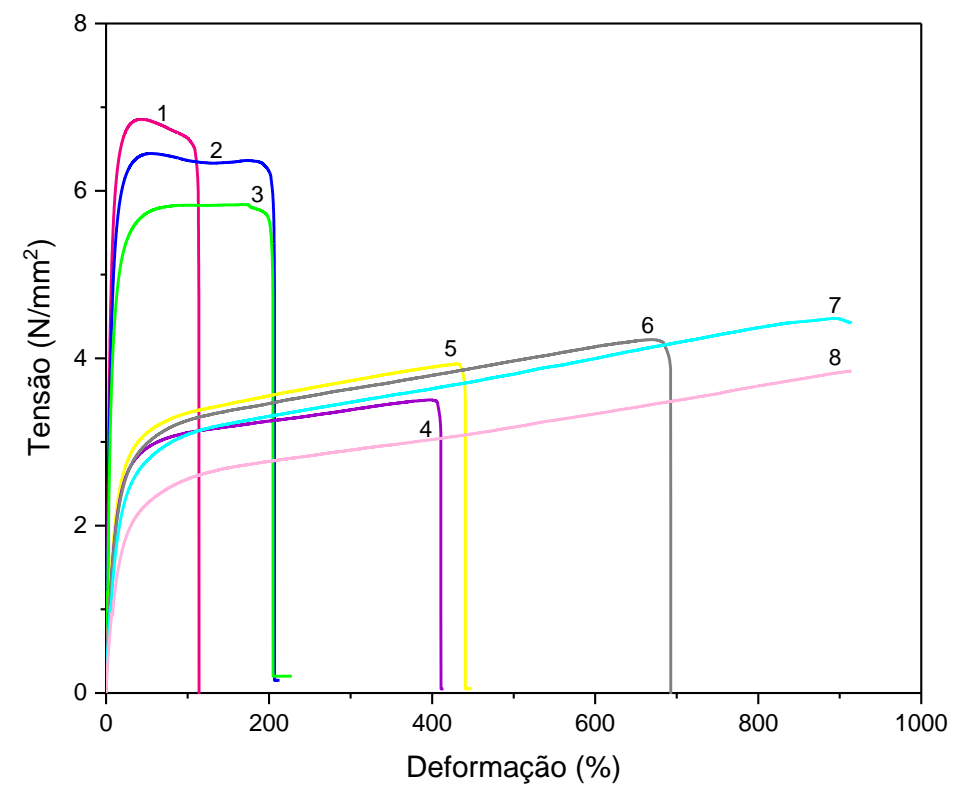

Fonte: Própria do autor. 
Pode-se observar que as três primeiras curvas referentes aos primeiros corpos de prova ensaiados apresentam uma tensão de escoamento (limite elástico) em torno de $6 \mathrm{~N} / \mathrm{mm}^{2}$. Contudo, os resíduos 4 a 8 apresentam uma tensão de escoamento em torno de $3 \mathrm{~N} / \mathrm{mm}^{2}$, duas vezes menor comparadas aos primeiros resíduos. Pode-se observar também que a ruptura acontece numa faixa de deformação entre $100 \%$ a $200 \%$ para os três primeiros corpos de prova. Por outro lado, para os corpos de prova 4 a 8 a ruptura acontece para uma deformação superior a 400\%. Pode-se notar que os corpos de prova 7 e 8 não apresentaram ruptura (Figura 36) durante o ensaio, o qual foi interrompido pelo limite do deslocamento da trava do equipamento de ensaio. Conforme a grande discrepância observada entre os corpos de prova ensaiados, provocada pela liberação de voláteis que percorreram o interior dos corpos de prova de forma aleatória e provocando defeitos, com uma maior concentração de macroporosidade, onde ocorreu a ruptura, sendo assim não é relevante definir propriedades mecânicas para este material. Entretanto, parece mais provável, a partir desse ensaio, que os corpos de prova possam apresentar uma heterogeneidade microestrutural considerável. Uma característica observável para este material é a sua alta capacidade elástica. A sua aderência nas superfícies metálica do equipamento e do molde de injeção também deve ser considerada. Isto deve ser causado pela presença dos adesivos presentes no material.

Embora a aplicação direta do resíduo CABE como polímero reciclado possa ser inviabilizada pelas dificuldades apresentadas durante o seu processamento por moldagem por injeção, o uso deste material na composição de outros materiais poliméricos pode apresentar resultados satisfatórios. 
Figura 37: Imagem dos corpos de prova do resíduo CABE após ensaio de tração.

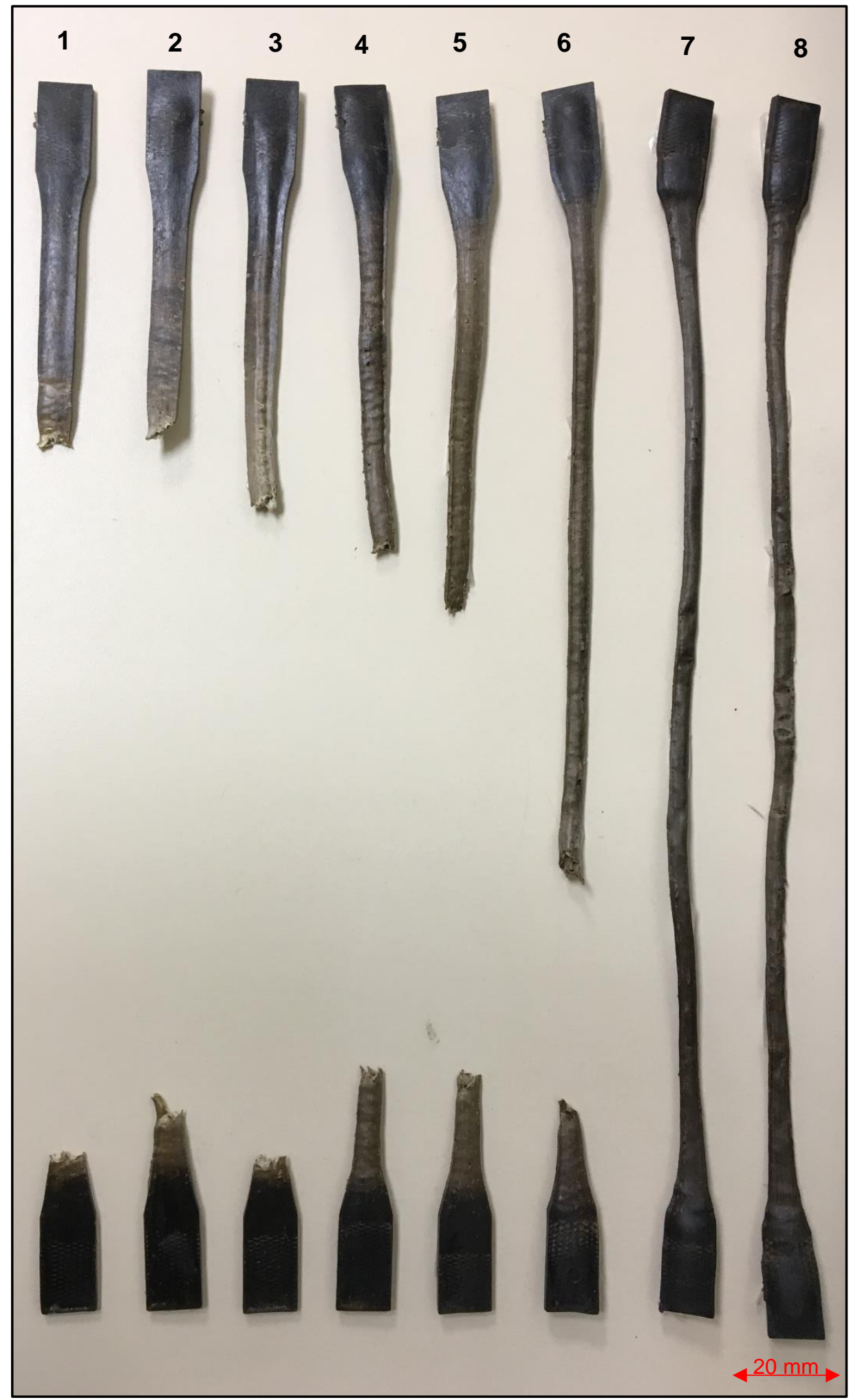

Fonte: Própria do autor. 


\section{- Ensaio de Impacto}

O ensaio mecânico de impacto foi realizado com o resíduo CABE. A Figura 38 mostra imagens dos corpos de prova antes e após esse ensaio.

Figura 38: Imagens de corpos de prova do resíduo CABE utilizados no ensaio de resistência ao impacto Izod: a) antes do ensaio e b) após o ensaio.

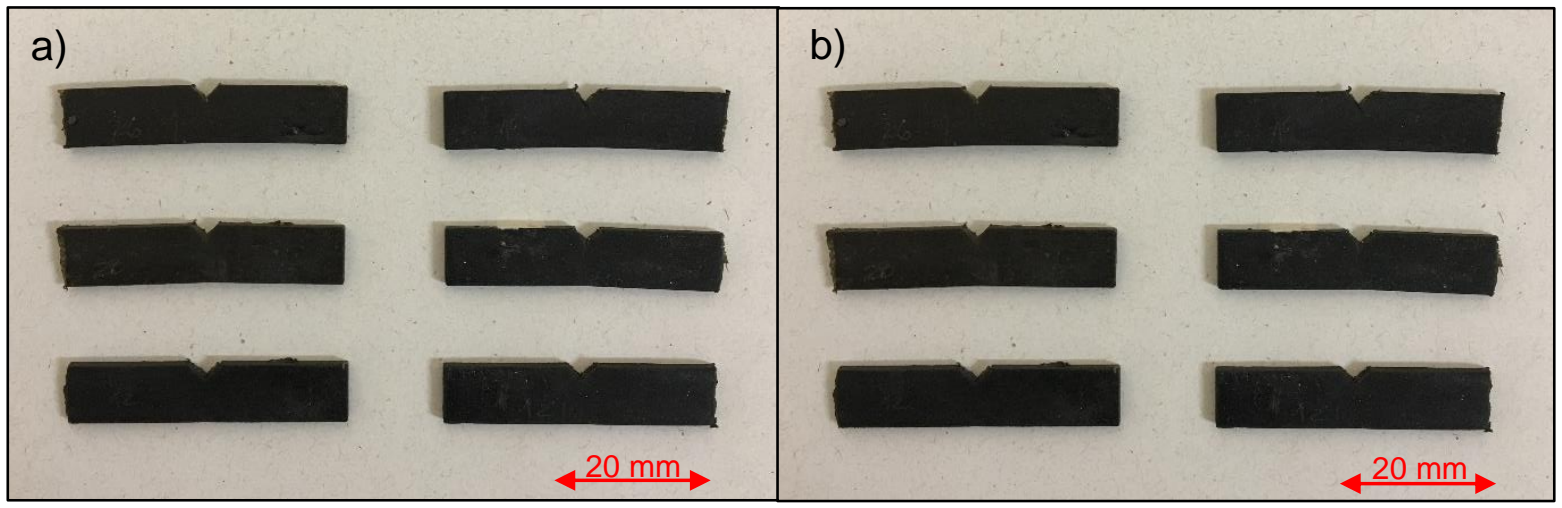

Fonte: Própria do autor.

Observa-se que o resíduo foi resistente ao impacto, não fraturando e nem deformando. Esse resultado se deve à composição final do resíduo $\mathrm{CABE}$, que apresentou uma elasticidade similar à de uma borracha, com deformação reversível do material. Portanto, conclui-se que o material reciclado CABE não é susceptível à fratura por impacto pela característica elastomérica apresentada.

\subsection{Reciclagem dos resíduos na forma de blendas poliméricas (etapa 4)}

Conforme discutido nas seções anteriores não é possível tecnicamente utilizar os resíduos em sua totalidade após extração da celulose em operações de moldagem por injeção dos materiais. Deste modo, foi avaliada como alternativa a incorporação da fração polimérica dos resíduos dos adesivos curativos com resíduos pós-industrais de PEBD, buscando atingir uma condição de processabilidade do material e consequente reaproveitamento completo dos resíduos. Neste sentido, os resíduos CABE, CABC, CABR e CAT, após extração da celulose, foram incorporados por extrusão ao resíduo pós-consumo de PEBD em proporções de 10\%, 15\% e 20\% em massa. 
A moldagem por injeção das blendas dos resíduos CABE, CABC, CABR e CAT com PEBD reciclado permitiu a confecção de corpos de provas sem a presença de defeitos ou liberação de voláteis, diferentemente do que ocorreu quando os resíduos foram injetados sem a presença de outro polímero. A Figura 39 apresenta imagens dos corpos de prova moldados.

Figura 39: Imagens dos corpos de prova moldados: a) Padrão; b) CABE 10 e 15\%; c) CABC 10,15 e $20 \%$; d) CABR 10, 15 e $20 \%$; e) 10, 15 e $20 \%$.

a) b)

c)

d)

e)

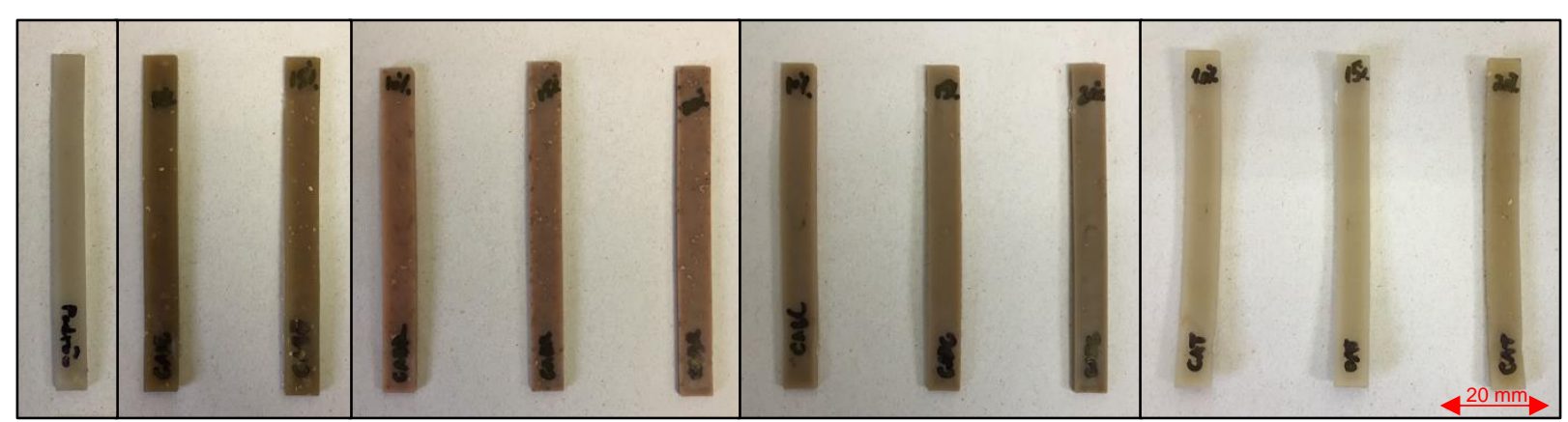

Fonte: Própria do autor.

A avalição do desempenho mecânico das blendas formadas foi feita por meio dos resultados de ensaios mecânicos de tração e impacto.

\section{- Ensaio de Tração}

A Figura 40 apresenta os resultados do ensaio de tração referente às blendas dos resíduos dos adesivos curativos após remoção da celulose com o PEBD reciclado. 
Figura 40: Resistência à tração das blendas PEBD pós-industrial com resíduos políméricos dos curativos adesivos: CABE (--); CABC (-०-); CABR (- $\left.\Delta^{-}\right)$e CAT (- -$)$.

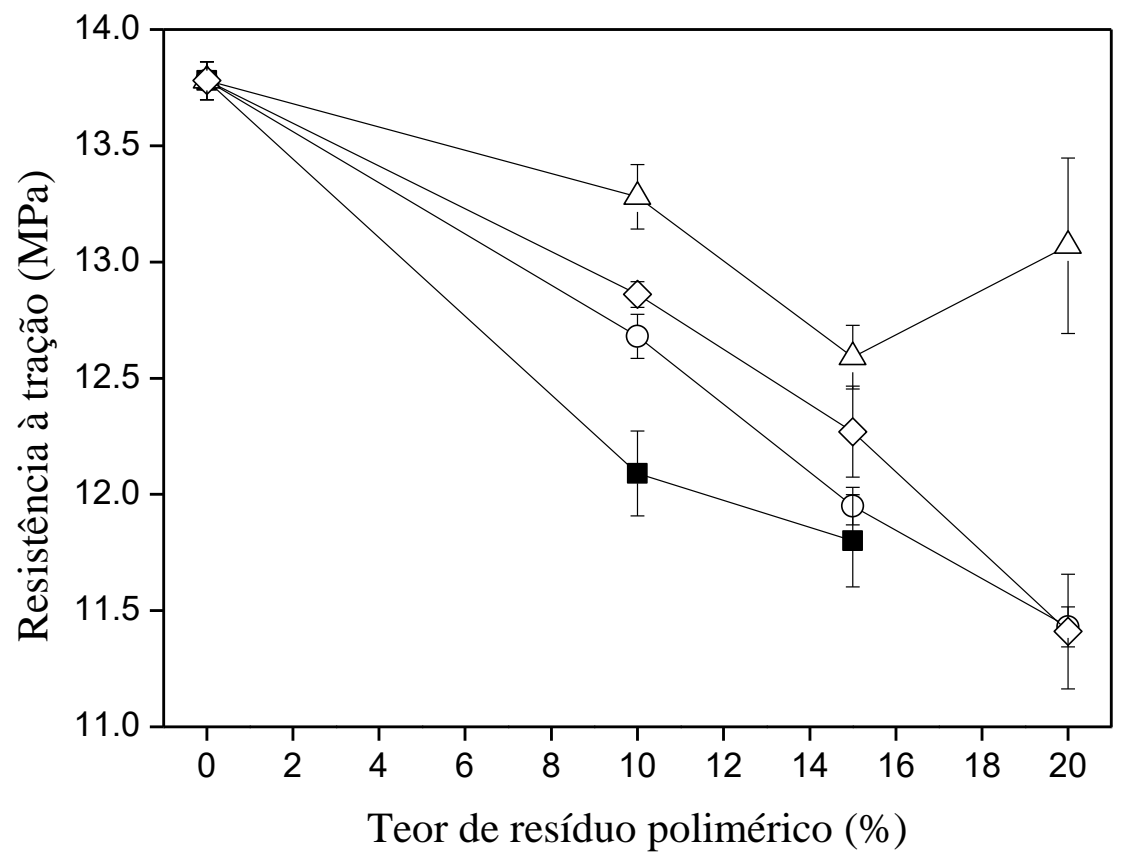

Fonte: Própria do autor.

Nota-se que a incorporação dos resíduos poliméricos dos adesivos curativos CABE, CABC e CAT provoca uma diminuição da resistência à tração do PEBD reciclado, reduzindo de aproximadamente $14 \mathrm{MPa}$ para $11,5 \mathrm{MPa}$ quando estes resíduos se encontram a $20 \%$ em massa na blenda. Por outro lado, a mudança de resistência à tração não pode ser considerada significativa com a incorporação do resíduo CABR. Apesar da redução de resistência à tração verificada, o valor de 11 MPa ainda permance em uma escala aceitável para a aplicação do polietileno, mostrando que a estratégia de incorporação do resíduo ao PEBD reciclado tem sido viável. 
A Figura 41 apresenta os resultados de módulo de Young para os resíduos CABE, CABC, CABR e CAT.

Figura 41: Módulo de Young das blendas PEBD pós-industriais com resíduos poliméricos dos curativos adesivos: CABE (--); CABC (-o-); CABR (- - -) e CAT (-৩-).

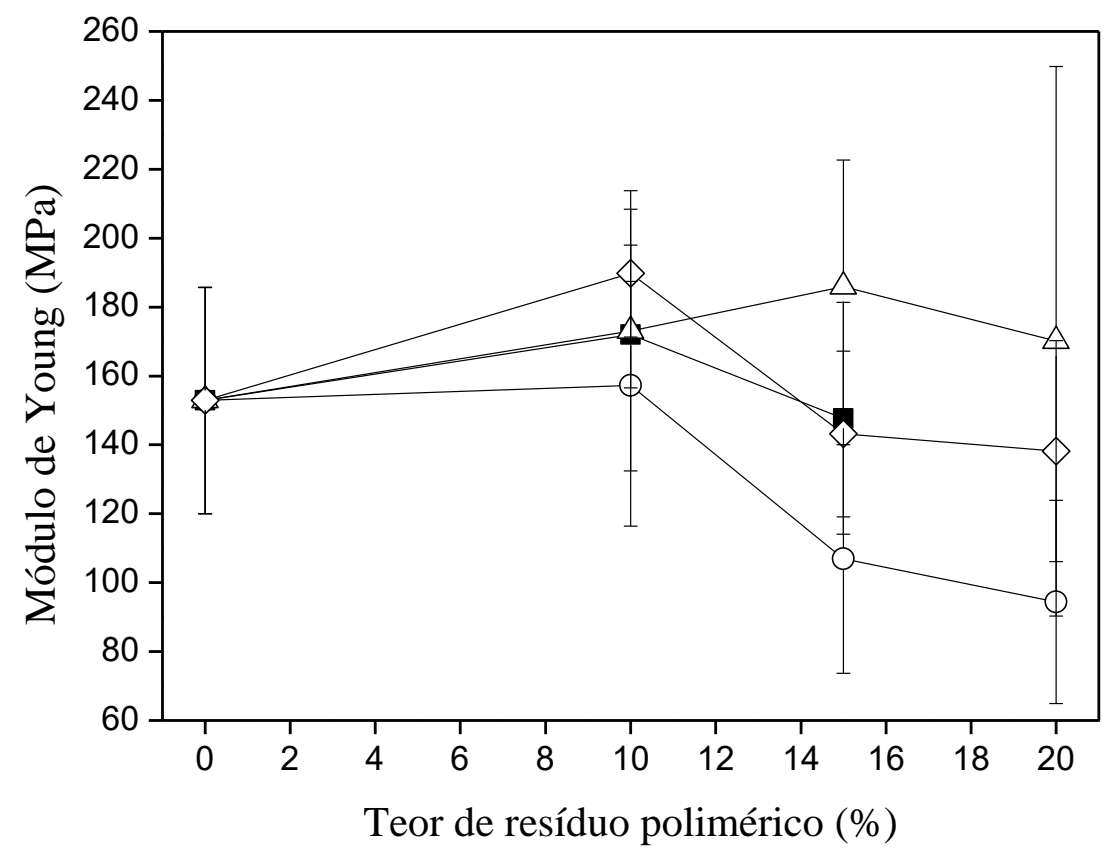

Fonte: Própria do autor.

O PEBD reciclado apresenta módulo de Young em torno de $150 \mathrm{MPa}$ e embora a incorporação dos resíduos cause alguma flutuação neste valor, todas as composições apresentam interposição de valores de desvio padrão, definindo as mudanças como não significativas. Assim, o módulo de Young mostra que é possível incorporar os resíduos poliméricos dos adesivos curativos ao PEBD reciclado sem prejuízos desta propriedade. 
A Figura 42 apresenta os resultados de alongamento na ruptura para os resíduos CABE, CABC, CABR e CAT.

Figura 42: Alongamento na ruptura das blendas $\mathrm{PEBD}$ pós-consumo com resíduos polímeros dos adesivos curativos: CABE (--); CABC (-०-); CABR (- $\Delta-)$ e CAT (-৩-).

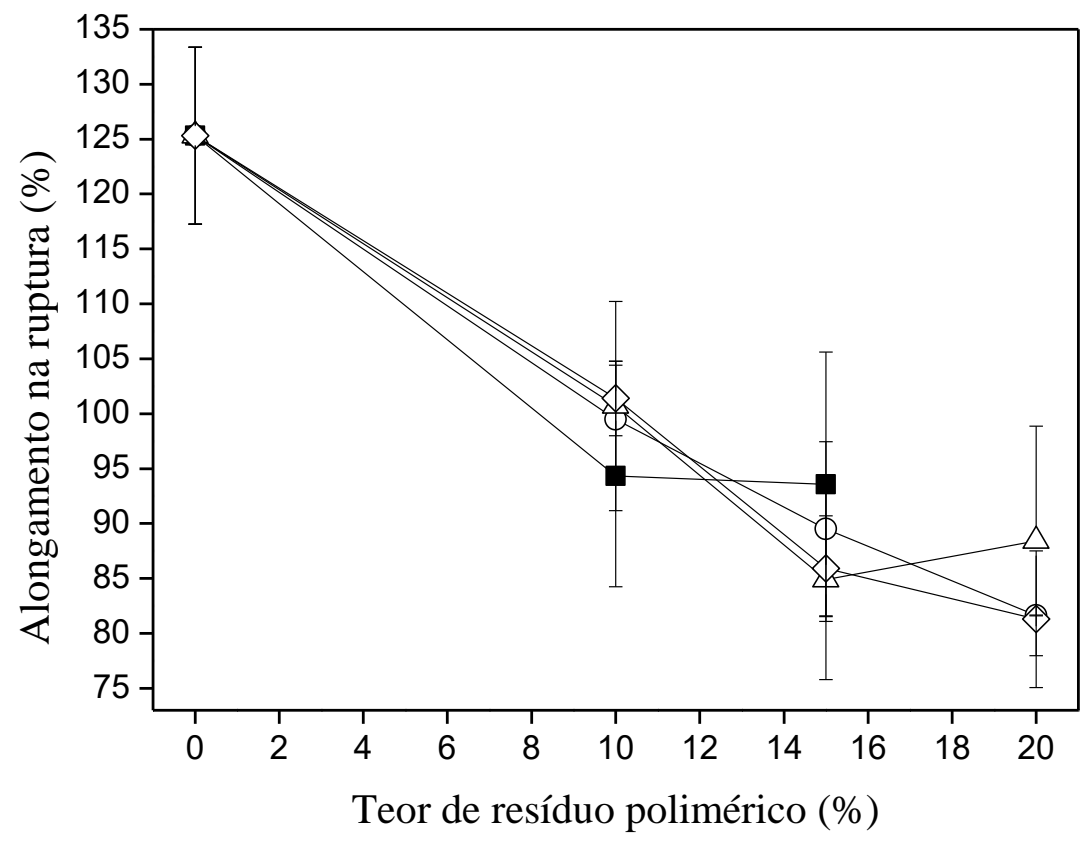

Fonte: Própria do autor.

O alongamento na ruptura do PEBD reciclado é de $125 \%$ e esta propriedade é reduzida progressivamente até atingir valores em torno de $80 \%$ quando os resíduos poliméricos dos adesivos curativos são incorporados ao PEBD reciclado no teor de 20\% em massa. Embora a redução do alongamento na ruptura tenha sido significativa, o valor no patamar de $80 \%$ ainda é considerável e aceitável para a maioria das aplicações que envolvem o PEBD. Desta forma, os resultados de alongamento na ruptura corroborram com a afirmação de que a incorporação dos resíduos poliméricos dos adesivos curativos ao resíduo pós-industrial de PEBD é uma alternativa adequada para a reciclagem do material ${ }^{53}$. 


\section{- Ensaio de Impacto}

A Figura 43 apresenta os resultados de resistência ao impacto dos materiais.

Figura 43: Resistência ao impacto das blendas PEBD pós-consumo com resíduos polímeros dos adesivos curativos: CABE (--); CABC (-o-); CABR (- $\Delta-)$ e CAT (- -$)$.

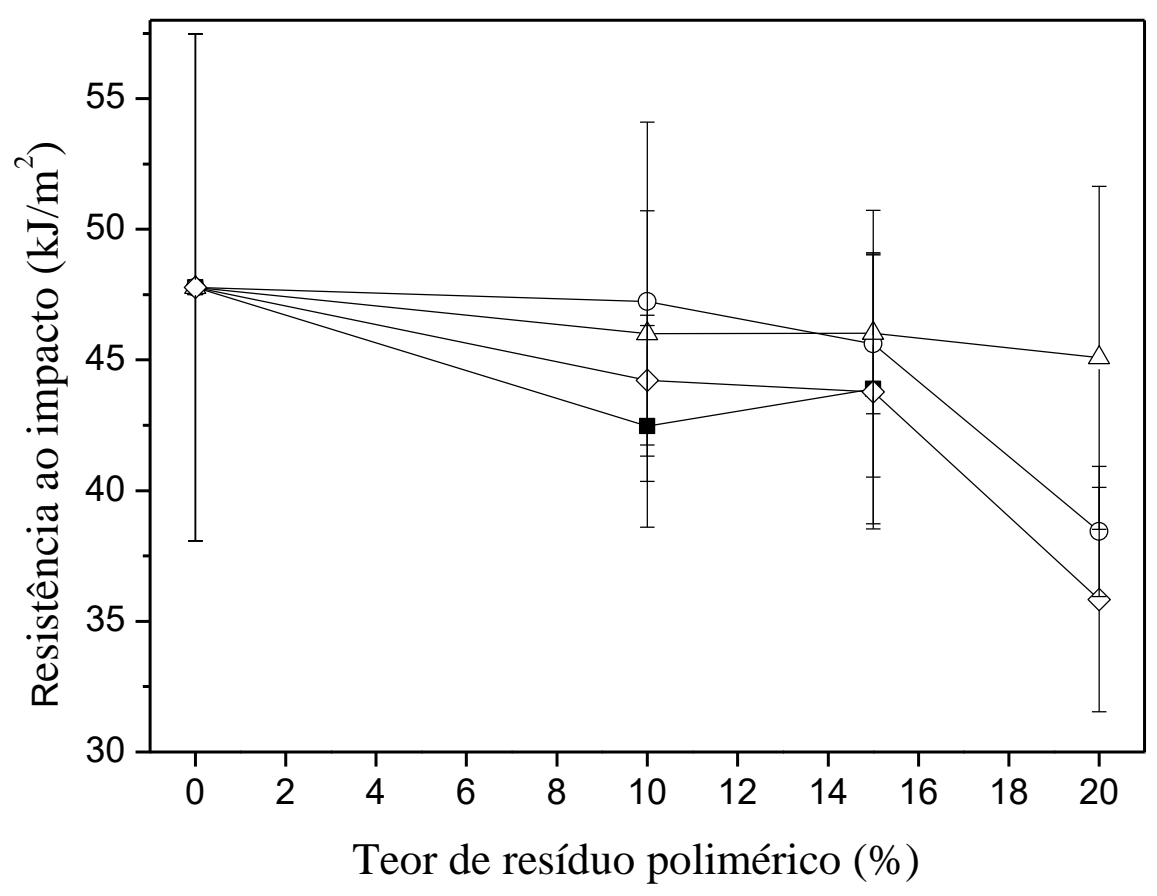

Fonte: Própria do autor.

Verifica-se que a incorporação dos resíduos poliméricos dos adesivos curativos ao PEBD reciclado em até $15 \%$ em massa não provoca mudanças siginificativas na resistência ao impacto do polímero, permanecendo em torno de $45 \mathrm{~kJ} / \mathrm{m}^{2}$. Uma tendência de redução no valor de resistência ao impacto pode ser notada com a adiação dos resíduos CABC e CAT em $20 \%$ em massa no PEDB reciclado. Entretanto, a interposição dos valores de desvio padrão das medidas não permite confirmar que há variação significativa da resistência ao impacto dos materiais. Assim como nas propriedades de resistência à tração e módulo de Young, o resíduo CABR foi o que mostrou a menor variação da média dos valores de resitência ao impacto em função de sua incorporação no PEBD reciclado. 
Os resultados de resistência ao impacto denotam uma relevância positiva quanto à incorporação dos resíduos poliméricos dos adesivos curativos ao PEBD reciclado, uma vez que é possível utilizar até $20 \%$ em massa na composição da blenda com o PEBD reciclado sem que haja mudanças consideráveis nesta propriedade. 


\section{CONCLUSÕES}

Os adesivos curativos são constituídos por materiais poliméricos sintéticos e celulose dispostos basicamente em quatro camadas sobrepostas que tornam a reciclagem mecânica do material uma operação complexa.

A sequência mais viável para a reciclagem mecânica dos resíduos se baseou primeiramente na separação e recuperação da celulose por meio da técnica de hidropolpação. A técnica de hidro-polpação, empregando somente água e sem a presença de aditivos químicos, foi bem-sucedida para os quatro diferentes resíduos, permitindo a recuperação de aproximadamente $50 \%$ da massa inicial dos resíduos na forma de celulose com alto teor de pureza que pode ser utilizada em diversas aplicações comerciais. Considerando a simplicidade das operações para a recuperação da celulose e a qualidade do produto obtido, esta fase da reciclagem apresenta grande potencial para ser utilizada em grande escala.

A porção remanescente dos resíduos após a remoção da celulose é constituída predominantemente por polietileno e outros polímeros na forma de adesivos e copolímeros, além de uma pequena fração de celulose que ainda permanece presente no resíduo após hidro-polpação. Esta porção polimérica é passível de processamento termomecânico por extrusão, permitindo eventualmente sua utilização em aplicações específicas. Entretanto, a moldagem por injeção se mostra inviável devido à liberação intensa de voláteis em virtude da decomposição de componentes do resíduo, tais como adesivos.

A incorporação com resíduos pós-industriais de polietileno de baixa densidade (PEBD) foi a alternativa encontrada mais adequada para a reciclagem da fração polimérica dos resíduos dos adesivos curativos. Assim, é possível incorporar os resíduos poliméricos dos adesivos em até $20 \%$ em massa ao resíduo de PEBD pósindustrial sem haver mudanças nas propriedades mecânicas do material que possam impedir seu uso como material reciclado. Deste modo, é possível reciclar todos os constituintes dos resíduos dos adesivos curativos por meio de técnicas e operações de uso industrial no setor de reciclagem mecânica de polímeros.

O presente estudo demonstrou que mesmo os resíduos poliméricos multicomponentes são passíveis de reciclagem mecânica em processos com grande possibilidade de viabilidade técnica e financeira, podendo gerar materiais reciclados com propriedades aceitáveis para uso comercial. Assim, é possível converter resíduos 
poliméricos pós-industriais que são descartados em aterros sanitários e que geram problemas ambientais e de gerenciamento de resíduos sólidos em materiais reciclados com novo ciclo de vida útil. 


\section{REFERÊNCIAS *}

1. FERREIRA, C. T. et al. Reciclagem de rejeitos de poli (tereftalato de etileno) (PET) e de poliamida (PA) por meio de extrusão reativa para a preparação de blendas. Polímeros, v. 21, p. 118-122, 2011.

2. PLASTICS - THE FACTS 2018, An analysis of European plastics production, demand and waste data. 2018. Disponível em: https://www.plasticseurope.org/application/files/6315/4510/9658/Plastics_the_facts_2 018_AF_web.pdf. Acesso em: 17 out. 2019.

3. QUISPE, N. B. et al. Organoclay nanocomposites of post-industrial waste poly(butylene terephthalate) from automotive parts. Waste Management \& Research, v. 33, p. 908-918, 2015.

4. ODIAN, G. Principles of polymerization. 4th ed. New York: Wiley, 2004. 832 p.

5. UNITED NATIONS, Department of Economic and Social Affairs. World population projected to reach $\mathbf{9 . 7}$ billion by 2050. 2015. Disponível em: http://www.un.org/en/development/desa/news/population/2015-report.html. Acesso em: 07 dez. 2016.

6. HAMAD, K. et al. Recycling of waste from polymer materials: an overview of the recent works. Polymer Degradation and Stability, v. 98, p. 2801-2812, 2013.

7. HOPEWELL, J. et al. Plastics recycling: challenges and opportunities. Phil. Trans. R. Soc., v. 364 (B), p. 2115-26, 2009.

8. CANEVAROLO JR., S. V. Ciência dos polímeros, 3a ed. São Paulo: Artliber, 2010. $280 \mathrm{p}$.

* De acordo com a Associação Brasileira de Normas Técnicas. NBR 6023. 
9. BAHRAMIAN, B. et al. A renewable and compostable polymer for reducing consumption of non-degradable plastics. Polymer Degradation and Stability, v. 133, p. 174-181, 2016.

10. ALLWOOD, J. M. Sustainable materials. Nature Review Materials, v. 1, n.1, p. 12, 2016.

11. CORSTEN, M. et al. The potential contribution of sustainable waste management to energy use and greenhouse gas emission reduction in the Netherlands. Resources, Conservation and Recycling, v. 77, p. 13-21, 2013.

12. YARAHMADI, N. et al. Polylactic acid and its blends with petroleum-based resins: effects of reprocessing and recycling on properties. J. Appl. Polym. SCI., v. 133, n. 36, p. 43916-25, 2016.

13. ABIPLAST. ASSOCIAÇÃO BRASILEIRA DA INDÚSTRIA DO PLÁSTICO. Disponível em: http://file.abiplast.org.br/download/2016/perfil_2015_ok.pdf. Acesso em: 01 out. 2019.

14. FÁVARO, SL. et al. PET and aluminum recycling from multilayer food packaging using supercritical ethanol, J. of Supercritical Fluids, v. 75, p. 138-143, 2013.

15. ASSOCIAÇÃO BRASILEIRA DE NORMAS E TÉCNICAS. ABNT NBR 10004:2004, 2a ed. Rio de Janeiro: ABNT, 2004. 19 p.

16. BRASIL. Lei no 12.305, de 02 de agosto de 2010. Institui a Política Nacional de Resíduos Sólidos. Disponível em: http://www.planalto.gov.br/ccivil_03/_ato20072010/2010/lei/l12305.htm. Acesso em: 08 dez. 2016.

17. GONZÁLEZ, I. V. et al. Os riscos ambientais da indústria de adesivos, Desenvolv. Meio Ambiente, v. 38, p. 787-802, 2016. 
18. PAOLI, M. DE. Degradação e estabilização de polímeros. São Paulo: Artliber, 2009. $286 \mathrm{p}$.

19. SPINACÉ, M. A. S. et al. A tecnologia da reciclagem de polímeros. Quím. Nova, v. 28, n. 1, 2005.

20. VILAPLANA, F. et al. Quality concepts for the improved use of recycled polymeric materials: a review. Macromol. Mater. Eng., v. 293, p. 274-297, 2008.

21. MANG, T. et al. Recycling of polymeric composites. Macromol. Svmp., v. 135, p. 147-156, 1998.

22. ANDRADE, M. F. C. et al. Life cycle assessment of poly(Lactic Acid) (PLA): comparison between chemical recycling, mechanical recycling and composting. $\mathbf{J}$. of Polym. Environ., v. 24, p. 372-384, 2016.

23. LI, X. et al. Environmental and financial performance of mechanical recycling of carbon fibre reinforced polymers and comparison with conventional disposal routes. Journal of Cleaner Production, v. 127, p. 451-460, 2016.

24. TARTAKOWSKI, Z. Recycling of packaging multilayer films: new materials for technical products. Resources, Conservation and Recycling, v. 55, p. 167-70, 2010.

25. LEE, Y.C. et al. Recycling of wasted multi-layer containing aluminium layer. In: INTERNATIONAL SYMPOSIUM ON EAST ASIAN RESOURCES RECYCLING TECHNOLOGY, 8., 2005, TMS, Pennsylvania, USA. p. 370-71.

26. MARTÍNEZ-BARRERA, G. et. al. Waste cellulose from tetra pak packages as reinforcement of cement concrete. Advances in Materials Science and Engineering, v. 2015, p. 1-6, 2015.

27. KORKMAZ, A., et al. Pyrolysis of the tetra pak. Waste Management, v. 29, p. 2836-41, 2009. 
28. LANDIM, A. P. M. et al. Sustainability concerning food packaging in Brazil. Polímeros-Ciência e Tecnologia, v. 26, p. 82-92, 2016.

29. RODRíGUEZ-GÓMEZ, J.E. et al. Development of a process using a waste vegetable oil for separation of aluminium and polyethylene from Tetra Pak. Fuel, v. 149, p. 90-94, 2015.

30. AGAMUTHU, P.; VISVANATHAN, C. Extended producers' responsibility schemes for used beverage carton recycling. Waste Management \& Research, v. 32, p. 1-3, 2014.

31. LIANG, B.H. et al. Recycled fiber quality from a laboratory-scale blade separator/blender. Forest Products Journal, v. 44, p. 47-50, 1994.

32. BYOUNG-UK CHO B. et al., Factors influencing deflaking kinetics in repulping to produce molded pulp. Journal of Industrial and Engineering Chemistry, v. 15, p. 119-123, 2009.

33. KENNEY, J. F. et al. Medical-grade acrylic adhesives for skin contact. Journal of Applied Polymer Science, v. 45, p. 355-361,1992.

34. BAND-AID, Brand adhesive bandages. Disponível em: https://www.bandaid.com/. Acesso em: 27 jun. 2017.

35. DOOLEY, J. et al. Development of microlayer blown film technology by combining film die and layer multiplication concepts. Polymer Engineering and Science, v. 56, p. 598-604, 2016.

36. VIDAL, R. et al. Environmental assessment of biodegradable multilayer film derived from carbohydrate polymers. J. of Polym. Environ. v. 15, p.159-168, 2007.

37. CHEN, H. et al. Preparation and properties of paper-plastic laminating adhesive used for medical packaging materials. Polym. Adv. Technol., v. 26, p. 1065-1069, 2015. 
38. MALLIKARJUNACHARI, G. et al. Nanomechanical study of polymer-polymer thin film interface under applied service conditions. J. of Appl. Polym. Sci., v. 133, p. 43532-45, 2016.

39. FRIED, J. R. Polymer science \& technology. 2nd ed., Upper Saddler, NJ: Prentice Hall College Div, 2003. 608 p.

40. UEHARA, G. A. et al. Recycling assessment of multilayer flexible packaging films using design of experiments. Polímeros, v. 25, p. 371-381, 2015.

41. STEVENS, M. P. Polymer chemistry: an introduction, New York: Oxford University Press, 1990. 633 p.

42. VALLIM M., R. et al. Polyamide-6/high-density polyethylene blend using recycled high-density polyethylene as compatibilizer: morphology, mechanical properties, and thermal stability. Polymer Engineering and Science, v. 49, p. 2005-14, 2009.

43. NAVARRO, R. et al. Process behavior of compatible polymer blends. Journal of Applied Polymer Science, v. 124, p. 2485-93, 2012.

44. RODRIGUEZ-GONZALEZ, F.J. et al. High performance LDPE/thermoplastic starch blends: a sustainable alternative to pure polyethylene. Polymer, v. 44, p. 151726, 2003.

45. GRILLO, C. C. Reciclagem de rejeitos de polietileno de baixa densidade provenientes de uma cooperativa de catadores na forma de madeira plástica. 2016. 89 f. Dissertação (Mestrado em Ciências) - Escola de Engenharia de Lorena, Universidade de São Paulo, Lorena, 2016.

46. MORENO, D. D. P. Blendas de rejeitos pós-industriais de filmes multicamadas de polietileno de baixa densidade (pebd) e poliamida (pa6). 2015. 103 f. Dissertação (Mestrado em Ciências) - Escola de Engenharia de Lorena, Universidade de São Paulo, Lorena, 2015. 
47. AMERICAN SOCIETY FOR TESTING AND MATERIALS. ASTM D638-10. Standart test method for tensile properties of plastics. West Conshohocken, 2013.

48. AMERICAN SOCIETY FOR TESTING AND MATERIALS. ASTM D256-34. Standard test methods for determining the izod pendulum impact resistance of plastics. West Conshohocken, 2002.

49. ARKAN, A. J. et al. Quality restoration of waste polyolefin plastic material through the dissolution-reprecipitation technique. Chemical Industry \& Chemical Engineering Quarterly, v. 20, p. 163-170, 2014.

50. COUTINHO, M. B. F. et al. Polietileno: principais tipos, propriedades e aplicações. Polímeros: Ciência e Tecnologia, v. 13, p. 1-13, 2003.

51. QUENTAL, C. A. et al. Linear low-density polyethylene characterization II. Fractionation by multiple-step isothermal crystallization from the melting state. Polímeros, v.15, p. 281-288, 2005.

52. NETZSCH. Thermal Properties of Polymers. Disponível em: www.netzsch.com. Acesso em: 24 jun. 2017.

53. WILLETT, J. L. Mechanical properties of LDPE/granular starch composites. Journal of Applied Polymer Science, v. 54, p. 1685-1695, 1994. 